\title{
Fidelidade de troquéis de gesso, obtidos a partir de moldes de cinco elastômeros, através de duas diferentes técnicas de moldagem
}

\section{Marco Polo Marchese}

Tese apresentada à Faculdade de Odontologia de Bauru, da Universidade de São Paulo, como parte dos requisitos para obtenção do Título de Doutor em Odontologia, na área de Dentística, opção Materiais Dentários. 


\section{Fidelidade de troquéis de gesso, obtidos a partir de moldes de cinco elastômeros, através de duas diferentes técnicas de moldagem}

\section{Marco Polo Marchese}

Tese apresentada à Faculdade de Odontologia de Bauru, da Universidade de São Paulo, como parte dos requisitos para obtenção do Título de Doutor em Odontologia, na área de Dentística, opção Materiais Dentários.

Orientador: Prof. Dr. Paulo Amarante de Araújo.

(Edição Revista)

BAURU

1999 


\section{Marchese, Marco Polo}

M332f Fidelidade de troquéis de gesso, obtidos a partir de moldes de cinco elastômeros, através de duas diferentes técnicas de moldagem / Marco Polo Marchese - Bauru, 1999. $162 \mathrm{p}$ : il. $10 ; 30 \mathrm{~cm}$.

Tese (Doutorado) - Faculdade de Odontologia de Bauru, USP.

Orientador: Prof. Dr. Paulo Amarante Araújo

Autorizo, exclusivamente para fins acadêmicos e científicos, a reprodução total ou parcial desta tese, por processos fotocopiadores e/ou meios eletrônicos.

Marco Polo Marchese

18 de Agosto de 1999 


\section{Marco Polo Marchese}

19 de Setembro de 1955

$1978 / 1981$

$1987 / 1988$

1992 / 1994

1994 / 1999

1995 / 1999

1999
Nascimento em Penápolis - São Paulo

Curso de Graduação em Odontologia de Uberaba, das Faculdades Integradas de Uberaba - M. G.

Curso de Especialização em Prótese Dental, na Faculdade de Odontologia de Marília, da Universidade de Marília

Curso de Pós - Graduação em Reabilitação Oral - Prótese, ao nível de Mestrado, na Faculdade de Odontologia de Bauru, da Universidade de São Paulo.

Professor Mestre III da Faculdade de Odontologia de Lins, Universidade Metodista de Piracicaba.

Curso de Pós - Graduação em Dentística (Materiais Dentários), ao nível de Doutorado, na Faculdade de Odontologia de Bauru, da Universidade de São Paulo.

Membro eleito do Conselho da Faculdade de Odontologia de Lins da Universidade Metodista de Piracicaba. 
Associações

Ensino Superior do Estado de São Paulo 


\section{A QUEM DEDICO E A QUEM ME DEDICO}

À MULHER que me ensinou "o que ser" e "como ser" no mundo":

"D $\mathbf{D}^{\text {na. }}$ NINA" (minha mãe) - a marca da perseverança, do orgulho, da força para a luta constante, apesar de todos os percalços.

À MULHER que me ensinou a sedimentar o "ser" que hoje sou

"VAL" - aquela que me ensinou a partilhar no mundo porque partilha o amor, a sinceridade, a compreensão, a amizade, as angústias e o carinho da esposa-mãe; Àquelas que, se hoje são crianças, amanhã serão MULHERES no mundo:

CAROLINA, MAURA e PAULA - filhas do amor e marca da esperança, para quem busco deixar o exemplo a ser seguido. 


\section{GRATO SOU}

À DEUS por "ser" e estar no mundo.

À meu pai “ANTONIO”, pelo espírito de força e luz: sempre a presença, na ausência do pai que tão cedo se foi.

Àqueles que tudo fizeram e muito contribuíram para que meu mundo fosse possível no passado, apenas um sonho - se fizesse o universo de experiência deste meu tempo presente:

Marco e Rachel: os irmãos de sempre;

Zuleika: a grande irmã;

Chiquinho: o cunhado constante, a ausência que hoje doe. DEUS deveria estar necessitando de uma estrela com o seu brilho, para leva-lo tão cedo.

Àqueles que, pelo carinho e amizade, sabem ser a família: o sogro e a sogra; os cunhados e as cunhadas; os sobrinhos e as sobrinhas, irmãos $\therefore$ e amigos, em especial ao Nelsinho e Betty. 
Ao Professor Doutor PAULO AMARANTE DE ARAÚJO que, através de uma orientação criteriosa, séria e amiga, não só me transmitiu conhecimento, mas me fez saber o quão agradável e fácil é a produção científica. Grato-lhe sou por ter despertado em mim interesse pela pesquisa e pelo ensino. 


\section{GRATO, AINDA, SOU:}

Ao Prof. Dr. CÉSAR ANTUNES DE FREITAS, o mestre, que soube incentivar e contribuir com o conhecimento tão necessário para a realização desta pesquisa. Obrigado? é muito pouco para quem ensina os caminhos distantes da pesquisa.

Ao Prof. NICÁCIO GARCIA HERNANDES, cuja simplicidade e inteligência o transformam em um homem ímpar, no contexto da Odontologia. Obrigado, pelo exemplo de ser humano. 
Ao Instituto Americano de Lins da Igreja Metodista, na pessoa de seu Diretor Geral Dr. Joaquim de Miranda Rosa e Filho do Sr. Dr. B. P. Bittencourt, que muito me ajudaram, obrigado pela oportunidade.

À Faculdade de Odontologia de Lins, da Universidade Metodista de Piracicaba, nas pessoas de seu Magnífico Reitor Prof. Dr. Almir de Souza Maia, do Diretor da Faculdade de Odontologia de Lins Prof. Dr. Carlos Wagner de A. Werner, e ainda, ao Prof. Dr. Antônio Carlos Usberti, ex-Diretor e Prof. Walter de Francisco, ex-Diretor Administrativo, por terem me auxiliado a concluir mais esta etapa.

Aos Professores Mitsuru Ogata, José Carlos Negrelli Muzegante, Maurício Tanji, pela colaboração e ensinamentos de vida transmitido, durante todos estes anos em que convivemos.

Aos Professores da Faculdade de Odontologia de Lins: André, Cabrera, Carlos Silveira, Doriana, Letícia, Luiz Sérgio, Madeira, Marília, Mário Ernesto, Xavier, Tanji e Dr. Valdir pelo apoio e incentivo, durante a realização deste trabalho, o que jamais esquecerei..

Aos funcionários da Faculdade de Odontologia de Lins, da Universidade Metodista de Piracicaba. 
Aos Professores da Disciplina de Materiais Dentários da Faculdade de Odontologia de Bauru - USP, Prof. Dr. César Antunes de Freitas, Prof. Dr. Paulo Amarante de Araújo, prof. Dr. Paulo Afonso Silveira Francischone e Prof. Dr Halim Nagem Filho.

Aos amigos da Pós-graduação, Haline, Heraldo, Ivan, João, Marcelo, Mário, Oscar, Regina e Yvone, obrigado pela bons momentos que passamos juntos e pelas palavras sempre amiga.

Aos funcionários, Sandrinha, Lô e Alcides, da Disciplina de Materiais Dentários da Faculdade de Odontologia de Bauru, da Universidade de São Paulo, pela amizade.

A todos aqueles que direta ou indiretamente contribuíram para a execução deste trabalho, meu muito obrigado. 
À Faculdade de Odontologia de Bauru, da Universidade de São Paulo, representada pelo seu Diretor, Prof. Dr. Aymar Pavarini, à Comissão dos Cursos de Pós-Graduação desta Faculdade, na pessoa do Prof. Dr. Luiz Fernando Pegoraro.

Ao Prof. Dr. José Roberto Pereira Lauris, pela valiosa colaboração durante a produção deste trabalho, pela sensibilidade e genialidade da análise estatística.

Aos Professores do Curso de Pós-Graduação, quer pelos ensinamentos, quer pelo relacionamento diário.

Aos funcionários da Faculdade de Odontologia de Bauru, da Universidade de São Paulo, em especial aos da Biblioteca, Clínica e da Secretaria de Pós-Graduação pela atenção com que sempre me atenderam. 


\section{SUMÁRIO}

Lista de Figuras xii

Lista de Tabelas do corpo do trabalho xiii

Lista de Quadros $\quad$ XV

Lista de tabelas e apêndice $\quad$ xvi

Resumo xvii

1. Introdução 1

2. Revisão de Literatura

3. Proposição 97

4. Material e Método 99

5. Resultados e Discussão 118

6. Conclusões 140

7. Referências Bibliográficas 142

8. Abstract 157

9. Apêndice 159 


\section{LISTA DE FIGURAS}

Figura 4.1 - Esquema do dispositivo de moldagem: B - base; M - moldeira perfurada; PM - parte móvel; T - troquel-padrão metálico; PFT parafuso fixador do troquel; CAFT - cilindro auxiliar de fixação do troquel; HV - haste vertical da base; PF -.parafuso fixador da moldeira; AMA - anel de manutenção da altura da parte móvel; AE - anel espaçador; CC - cilindro centralizador (original de ARAÚJO; JÖRGENSEN ${ }^{6}$ ).

Figura 4.2 - Esquema do troquel-padrão referido no texto, com toda as dimensões expressas em $\mathrm{mm}$.

Figura 4.3 - Fotografia do troquel-padrão metálico, visto principalmente por oclusal (com o ponto em depressão indicado pela seta) e, da coroapadrão em posição adequada, como descrito no texto.

Figura 4.4 - Fotografia do dispositivo de moldagem, após a fixação definitiva da moldeira em posição e do anel de manutenção de altura da parte móvel.

Figura 4.5 - Fotografia do conjunto de moldagem, após a fixação do casquete de moldagem em sua posição definitiva, da forma descrita no texto.

Figura 4.6 - Aspecto do conjunto de moldagem, para um caso qualquer da técnica da dupla moldagem, após a imobilização da parte móvel (PM) e antes do troquel ser removido do molde, como explicado no texto. 
Figura 4.7. - Aspecto de um molde escolhido aleatoriamente, para a técnica da dupla moldagem (em A), e do casquete (em B), na forma descrita no texto.

Figura 4.8 - Aspecto de um troquel de gesso obtido (a seta aponta o ponto em depressão - marca das 12 horas).

Figura 4.9 - Verticulador, com o cilindro centralizador fixado no seu ramo superior e com a peça de madeira (prendendo um troquel nivelado, através da massa de modelar verde) presa ao ramo oposto.

Figura 5.1 - Apresenta esquematicamente a distribuição dos valores expressos na tabela 5.1, em relação ao nível ideal (marca zero). 


\section{LISTA DE TABELAS DO CORPO DO TRABALHO}

Tabela 5.1 - Tabela 5.1 - Resultados médios individuais (em $\mu \mathrm{m})$, com as respectivas médias, da adaptação da coroa-padrão nos troquéis de gesso, obtidos dos cinco elastômeros (Exp - Express; Ipe Impregum; Ipi - Imprint; Prm - Permlastic; Pre - President), nas duas técnicas de moldagem (1 - dupla moldagem com alívio de 1 $\mathrm{mm} ; 2$ - com alívio de $2 \mathrm{~mm}$ e $\mathrm{C}$ - casquete), como descrito no texto. 


\section{LISTA DE QUADROS}

Quadro 5.1 - Resultado da análise de variância aplicada aos valores da tabela 5.1 .

*significante $(\mathrm{p}<0,01)$

Quadro 5.2 - Comparações efetuadas pelo teste de Tukey, ao nível de significância de $5 \%$.

Quadro 5.3 - Valores da adaptação da coroa-padrão, em módulo, ordenados em ordem decrescente, de cima para baixo, para todas as comparações efetuadas. As barras verticais indicam os grupos com desempenho estatisticamente semelhantes entre si. 


\section{LISTA DE TABELAS E APÊNDICE}

Tabela 9.1 - Medidas médias originais da adaptação da coroa-padrão nos troquéis de gesso, nos quatro locais escolhidos. 


\section{RESUMO}

As restaurações fixas são rotineiramente fabricadas sobre um modelo de gesso, obtidos a partir do molde de um dente preparado. A precisão na adaptação destas é influênciada diretamente pelas propriedades dos materiais de moldagem empregado. Qualquer que seja o elastomêro eleito, o método mais confiável para se avaliar o seu desempenho em conduzir a modelos de gesso fiéis, parece ser aquele no qual é empregado um coroa-padrão que se adapta com precisão a um troquel apropriado. Este trabalho tem por objetivo avaliar se dentre as técnicas da dupla moldagem (com alívio de 1 e $2 \mathrm{~mm}$ ) e a do casquete, existe uma mais adequada ou se ambas apresentam adequações suficiente e semelhantes. Foram empregados cinco elastômeros (Express, Impregum F, Imprint, Permlastic e President), os moldes foram obtidos empregando-se um dispositivo de moldagem idealizado por ARAÚJO e JÖRGENSEN ${ }^{6}$ e vazados com gesso especial tipo IV (Vel-Mix). A coroa-padrão foi posicionada nos troquéis e avaliada, quanto à sua precisão de adaptação, em um microscópio de medição de profundidade. Os resultados estatístico mostraram que a técnica do casquete apresentou melhores resultados para os materiais Impregum F e Imprint, vindos a seguir o Express e o President (ambos com alívio de $2 \mathrm{~mm}$ ) e o Express (alívio de $1 \mathrm{~mm}$ ); o Permlastic e o Express, na técnica do casquete, apresentaram piores resultados que os anteriores, mas semelhantes entre si, sendo o President (casquete) semelhante à este último; o President (alívio de $1 \mathrm{~mm}$ ), foi o que apresentou pior resultado. 
1 - Introdução 


\section{1 - Introdução}

A referência mais antiga do uso de um material de moldagem para a confecção de uma prótese, data de 1684, quando, segundo TEIXEIRA ${ }^{146}$, "Gottfried Purman utilizou cera para reproduzir dentes e maxilares".

As técnicas de moldagem, em sua evolução histórica, têm sido consideravelmente influênciadas pelos materiais de moldagem, podendo-se mesmo afirmar, que sofrem modificações consecutivas, pela constante colocação no mercado, de novos materiais, o mesmo pode ser dito das técnicas para a obtenção dos modelos e dos troquéis de trabalho.

As restaurações fixas são rotineiramente confeccionadas sobre um modelo de gesso, obtido a partir do molde de um dente preparado. A precisão destas restaurações, no que diz respeito ao seu assentamento ou adaptação no dente, é influenciada diretamente pelas propriedades dos materiais de moldagem utilizados. Portanto, sua confecção requer moldagens morfo-dimensionalmente precisas. Uma melhor uniformidade na espessura do material de moldagem poderia ser conseguida com o auxílio de moldeira individual (casquete), o que também teoricamente melhoraria sua precisão.

O emprego destas moldeiras individuais, para melhorar a precisão dos moldes e subseqüentemente das respectivas próteses, têm sido relatado em estudos de diversos autores, tais como BAYLEY ${ }^{18}, \mathrm{BOMBERG}^{26}, \mathrm{BOULTON}^{30}, \mathrm{GORDON}^{70}$, MITCHELL; DAMELE ${ }^{111}$, PAYNE; PEREIRA ${ }^{117}$, PODSHADLEY ${ }^{124}$ VALLE $^{148}$, VALDERHAUG; FLÖYSTRAND ${ }^{149}$. Se houver vantagem, na precisão dimensional, com o emprego destas, a firme retenção do material de moldagem à elas é fundamental. PHILLIPS $^{120}$ afirma que, no geral, os adesivos para os polissulfetos, poliéteres e siliconas de condensação são satisfatórios, mas que os empregados para as siliconas de adição são os menos efetivos.

De acordo com PHILLIPS ${ }^{121}$, um material de moldagem ideal seria aquele que pudesse reproduzir com precisão a forma dos dentes e as suas relações com as 
estruturas vizinhas, devendo ainda ser suficientemente elástico para ser removido das áreas retentivas e voltando à sua forma original, não permitindo distorções. Para SANSIVIERO et al. ${ }^{130}$, o elastômero é definido, quando polimerizado e com base em características de seu comportamento à temperatura ambiente, como um material "capaz de ser distendido até pelo menos o dobro de seu comprimento original, readquirindo depois, forçosa e rapidamente, o seu comprimento inicial. Assim, o material oferece a possibilidade de poder ser "trabalhado" (ou manipulado), quando no estado original. Todavia, após a reação de polimerização, está obrigado a manter tamanho e forma copiadas". De um modo geral, todos os materiais elastomérico sofrem uma ligeira contração durante a sua polimerização, como resultado da redução em seu volume devido às ligações cruzadas

De acordo com a American Dental Association (A. D. A.) ${ }^{3}$, os elastômeros podem ser classificados como mercaptanas (ou tio-álcoois ou ainda polissulfetos), siliconas (de adição ou de condensação) e poliéteres.

Por volta de 1953, iniciou-se uma nova era na Odontologia com o surgimento do primeiro material de moldagem à base de borracha sintética, conhecido comercialmente como mercaptana, sendo que, os primeiros relatos no emprego destes materiais, foram feitos por "Fettes; Jorczak" apud BELL; FRAUNHOFER ${ }^{22}$, com grandes vantagens sobre os hidrocolóides reversíveis.

A introdução das siliconas no mercado odontológico ocorreu no final da década de 50, época em que elas apresentavam características que conferiam significativas alterações morfo-dimensionais aos moldes (por apresentarem polimerização por condensação), levando à obtenção de modelos com pouca precisão. Por volta de 1960, apareceram na Alemanha os poliéteres. Em meados da década de 70, as silicona sofreram alterações estruturais, eliminando o aparecimento de subprodutos durante o processo de polimerização, assim surgindo as de polimerização por adição, também com grande capacidade de reprodução de detalhes, mas com maior fidelidade morfo-dimensional. 
O surgimento destes materiais possibilitou aos profissionais da área condições de obterem moldes unitários ou múltiplos de dentes preparados, com maior precisão de detalhes, devido às suas propriedades. Os resultados das moldagens realizadas com estes materiais são traduzidos pela confecção de modelos e troquéis, sendo os gessos, os eleitos para este fim. O poder de cópia do material de moldagem, associado à boa qualidade reprodutiva do gesso, permite a obtenção de modelos mais fiéis dos dentes preparados, propiciando aos profissionais, a realização de trabalhos com maior precisão. As alterações dimensionais durante a polimerização dos elastômeros têm sido medidas de forma direta ou indireta, empregando-se corpos de prova padrões, de diversas formas.

O uso das siliconas, em geral, têm demonstrado ser uma ótima opção como material de moldagem, constituindo um dos materiais de moldagem mais testados na história da Odontologia. No exterior, a silicona de adição é hoje o material de moldagem mais utilizado, como pode ser observado pela análise do grande número de trabalhos existentes. Em nosso país, parece estar havendo um aumento do número de profissionais que com elas trabalham. Contudo, devido talvez ao seu alto custo, a mercaptana e a silicona de condensação são ainda muito usadas.

O grande número de pesquisas, analisando consistência, tempos de trabalho e de polimerização, deformação permanente, estabilidade morfo-dimensional, flexibilidade, rasgamento e compatibilidade com os materiais de modelos, dentre outros aspectos, deve ser considerada no todo, conjuntamente com outras variáveis, tais como, odor, potencial para manchar roupas, facilidade de manipulação, controle de escoamento, possibilidade de visualização de detalhes copiados ou de permitir a obtenção de vários moldes, adequadamente, aceitação clínica e capacidade de sofrer desinfecção, sem problemas.

A título de curiosidade, a silicona de adição foi "desenvolvida durante o projeto Apollo e usada na bota do comandante Armstrong, com a qual ele pisou na Lua”, segundo relato de BROWN ${ }^{34}$, em 1981. 
Qualquer que seja o elastômero eleito, o método mais confiável para se avaliar seu desempenho em conduzir a modelos de gesso fiéis é aquele no qual é usada uma peça padronizada (coroa-padrão, que simule aquelas obtidas por fundição), a qual se adaptasse com grande precisão em um troquel padrão, precisão esta avaliada através de um microscópio de profundidade, como foi observado no trabalho de MARCHESE $^{97}$.

Dentro desse quadro teórico, uma dúvida que parece estar ainda sempre presente é se, dentre as técnicas da dupla moldagem e a do casquete, existe uma mais adequada ou se ambas apresentam adequação suficiente e igual (ou semelhante). 
2 - Revisão de literatura 


\section{2 - Revisão de literatura}

BAILEY $^{18}$, 1955, chamava a atenção para as vantagens dos materiais à base de borracha sobre os outros materiais de moldagem, afirmando que esses, possuíam uma boa estabilidade dimensional; não havia necessidade de se vazar o molde até 30 minutos após sua confecção, como os hidrocolóides; poderia ser feito um revazamento de um mesmo molde; a fidelidade igual à dos hidrocolóides, e acreditava que os bons resultados alcançados seriam devido ao emprego de moldeiras rígidas.

SKINNER; COOPER ${ }^{136}$, em 1955, testaram oito marcas comerciais de materiais de moldagem à base de borracha, avaliando o tempo de espatulação e polimerização e suas propriedades elásticas nas temperaturas de $25^{\circ} \mathrm{C}$ e $37^{\circ} \mathrm{C}$. Seis dos materiais testados foram avaliados quanto à sua precisão de reprodução. Foi realizado, ainda, um outro teste para avaliar as condições de manipulação. O tempo de manipulação dos materiais variaram de 3 a 9 minutos, e o de polimerização de 5 a 12,30 minutos, para a temperatura $25^{\circ} \mathrm{C}$ e, de 2 a 4 minutos e 3 a 7,30minutos , respectivamente, quanto a $37^{\circ} \mathrm{C}$. Concluíram que, um aumento na temperatura e na umidade, ou somente nesta, causaria uma diminuição nos tempos de manipulação e de polimerização. Durante o período de estocagem, de 5 meses, em temperatura ambiente, a vida útil dos materiais se mostraram satisfatória, indicada pelo fato de que nenhuma mudança significante ocorria no tempo de polimerização, após este período. As propriedades elásticas, após 30 minutos da polimerização, foram as mesmas encontradas para os hidrocolóides. Quando estas foram testadas - após o material ter sido deixado em água a $37^{\circ} \mathrm{C}$, por 3 minutos e depois deixados polimerizarem a $25^{\circ} \mathrm{C}$ suas propriedades mantiveram-se satisfatórias. A dureza superficial dos gessos, não sofria reduções, quando em contato com os materiais de moldagem testados. Moldagens com camada de espessura uniforme e fina apresentavam maior precisão do que quando espessas. Ainda segundo os autores, a estabilidade dimensional dos materiais, à base de borracha, é muito boa, quando se emprega uma técnica correta, 
embora uma moldagem precisa possa ser obtida com a técnica da dupla mistura, o uso rotineiro desta técnica não é recomendada devido à tendência ao "stress" induzido e, o melhor método, para reter o material à moldeira, é pelo emprego de adesivos.

Uma nova técnica moldagem ou o seu aperfeiçoamento, tem os fundamentos embasados nas propriedades físicas e mecânicas dos materiais. Entretanto, com a introdução de novos tipos de materiais, informações consideráveis devem ser obtidas destas propriedades, à medida que o material será empregado para a obtenção de resultados melhores nas técnicas odontológicas. FAIRHURST et al. ${ }^{63}$, em 1956, estudaram as propriedades elásticas dos materiais de moldagem à base de borracha, desde o iníco da confecção do molde até a sua remoção da boca, para determinar seu grau de reprodutibilidade. Concluíram que a maioria destes materiais tem suas propriedades elásticas consideravelmente melhoradas, quando são deixados em posição, por um período maior do que o estipulado pelos fabricantes, pois, após a polimerização, a maioria, exibem excelentes propriedades elásticas e de estabilidade, quando estocados, por um período de até 24 horas. A melhor reprodutibilidade, por longos períodos de estocagem, foi obtida com a utilização de moldeira individual em acrílico, que permitia uma espessura de 2 a $3 \mathrm{~mm}$ do material de moldagem.

Para STURDEVANT ${ }^{143}, 1957$, a melhora na confecção de uma restauração de ouro, tipo inlay, pelo método indireto, esta baseada no uso correto de dois materiais de moldagem: o hidrocolóide reversível e a recentemente introduzida mercaptana. Ambos são elásticos; nenhum outro material de moldagem dental é elástico, exceto o alginato (hidrocolóide irreversível); contudo, este não produz a precisão clínica do hidrocolóide reversível. Os autores estudaram a técnica da dupla mistura, com auxílio de uma seringa para mercaptana, empregaram moldeiras individuais, com alívio de 3 $\mathrm{mm}$ no seu interior, alegando que uma espessura menor do que $2 \mathrm{~mm}$ de material de moldagem determinaria uma ruptura no molde, no momento de sua retirada, visto que os adesivos mantém a união deste à moldeira. Recomendaram, ainda, que não se faça 
correções nas moldagens pela adição de uma nova camada de material e o posterior reacentamento. Concluíram, que, o vazamento, para a confecção do modelo, deveria ser realizado na primeira hora após a remoção do molde.

Para SKINNER ${ }^{137}$, 1958, os materiais de moldagem elastoméricos são classificados de acordo com sua composição, ou seja, à base de mercaptana ou à base de silicona. As subclasses de cada tipo podem ser designadas, de acordo com a sua viscosidade, após a mistura, como; "pesado, regular e fluido". O tempo de trabalho dos materiais variam de 3 a 9 minutos, o de polimerização de 6 a 13; sendo, que a silicona, geralmente, polimeriza mais rapidamente do que a mercaptana. Um aumento na temperatura, acelera o tempo de presa; principalmente para a mercaptana. O de polimerização da silicona pode ser controlado pela quantidade de acelerador empregado, mas a relação não é diretamente proporcional. O controle no tempo de polimerização da mercaptana pode ser alterado pela adição de uma gotade água para acelerar e, de uma pequena quantidade de ácido graxo, para retardar. Os melhores materiais de moldagem à base de borracha possuem propriedades elásticas iguais ou superiores às dos hidrocolóides. Todos contraem, após a polimerização; todavia, a silicona tende a contrair mais do que a mercaptana, apresentando estabilidade dimensional inferior. Por outro lado, a silicona, apresenta maior facilidade de manipulação, menor tendência a manchar, menor sensibilidade às mudanças de temperaturas e menor toxicidade, quando em contato com os tecidos.

Com a introdução da silicona, como uma alternativa para o material de moldagem à base de thiokol, esta despertou grande interesse. Em 1958, McLEAN ${ }^{105}$, avaliou o uso de três marcas comerciais de silicona, empregadas na odontologia restauradora, relacionando suas propriedades físicas com as técnicas clínicas. Concluiu que: 1) o tempo de vida útil das siliconas era limitado; 2) sua polimerização, ainda, continuava por duas semanas - após a polimerização inicial na boca - exibindo uma contração linear de 0,04 a 0,27\%, após 50 minutos; e de 0,36 a 0,82\%, após duas 
semanas de estocagem. Contudo, esta contração podia ser reduzida pelo uso de moldeiras perfuradas e, uma espessura de material de $4 \mathrm{~mm}$; sendo que o aumento desta levaria a uma maior instabilidade dimensional; 3) a força de tensão e a elasticidade da silicona era menor do que o thiokol e de manipulação mais facil, mas inferior aos hidrocolóides reversíveis e irreversíveis.

Para PHILLIPS $^{120}$, 1959, a precisão dos materiais de moldagem à base de borracha (polissulfetos e siliconas) comparam-se com a dos hidrocolóides reversíveis. A vantagem da siliconas é o fato de serem manipuladas com maior facilidade; entretanto, os polissulfetos possuem, atualmente, vida útil superior e são menos radicais no seu comportamento. A precisão de ambos os tipos, depende, segundo o autor, do uso de uma de espessura mínima de material; estar unida firmemente à moldeira, para que se tenha um bom molde; um tempo de trabalho mínimo de 8 minutos; o emprego da técnica da dupla mistura e de seringa sempre que possível e vazamento do molde deve ser o mais rápido quanto possível.

BRASS $^{32}$, em 1959, fez uma comparação entre os materiais para moldagem existentes, concluiu que; os hidrocolóides reversíveis e irreversíveis, dependendo do meio ambiente, estão sujeitos a alterações dimensionais e, sua metalização não é satisfatória; as siliconas possuem um tempo de armazenamento limitado, apesar da facilidade na sua manipulação, o que tem popularizado este material, também não são satisfatoriamente metalizadas; os modelos de gesso apresentam freqüentemente bolhas. O thiokol, uma borracha sintética, apresenta-se como um excelente material de moldagem, possuindo a maioria das propriedades desejadas, sendo sua elasticidade e fidelidade superiores aos seus predecessores; resultando em modelos mais precisos do que os outros materiais e sua fidelidade é excelente quando metalizado.

As técnicas de moldagem indireta envolvem vários tipos de materiais e são largamente empregadas na prática odontológica. Em 1960, AYERS et al. ${ }^{17}$, relataram 
que a precisão de reprodução está na dependência, do comportamento dimensional, dos materiais envolvidos e da compatibilidade do material de moldagem, frente ao empregado na confecção do modelo. Os autores avaliaram 10 materiais de moldagem (hidrocolóide reversível, alginato, polissulfeto e silicona) de 3 gessos (Vel-Mix, Duroc e Castone) bem como suas habilidades em reproduzir detalhes superficiais. Utilizaram um cilindro padrão de aço, com 3 escalas de 7 edentações, variando a largura e a profundidade, em micrometros. As moldagens e os gessos foram manipulados de acordo com os fabricantes; os moldes foram vazados 10 minutos, após a moldagem, e armazenados no máximo por 1 hora e no mínimo por 15 minutos, em um ambiente com umidade relativa do ar de 100\%. O mesmo experimento foi realizado por 2 laboratórios, na tentativa de evitar possíveis variações manipulativas. Concluíram que, as diferenças demonstradas, na habilidade de reprodução dos detalhes, dos vários materiais de moldagem, os polissulfetos, hidrocolóides reversíveis e siliconas, mostraram resultados excelentes; enquanto que os alginatos foram inferiores tanto pela sua conduta inerente, quanto na combinação deste com os 3 materiais de troquéis testados.

MILLER et al. ${ }^{109}, 1960$, estudaram as propriedades físicas de 14 materiais de moldagem à base de borracha sintética (10 polissulfetos e 4 siliconas), em relação: ao tempo de polimerização, na temperatura da cavidade oral; de trabalho e ao aumento da temperatura durante a polimerização. Para os autores, os materiais de moldagem odontológicos à base de borracha possuem propriedades físicas favoráveis, quando comparadas aos hidrocolóides reversíveis. Concluíram que: 1) na maioria das propriedades determinadas, entretanto, existem variações consideráveis entre as diferentes misturas dos materiais; 2) na temperatura da boca, o tempo de polimerização variou de 4 a 10 minutos; 4) no geral, as siliconas de condensação exibem menores deformações permanentes e maiores resistências do que os polissulfetos, quando testados após 10 minutos do início da espatulação. Todos os materiais testados foram compatíveis aos gessos. A maioria dos materiais apresentam depressões na sua 
superfície, poucas horas depois, embora o número e a magnitude destas variaram grandemente de um material para outro.

Durante os últimos três anos, tem aumentado consideravelmente as informações sobre as propriedades físicas dos materiais de moldagem à base de silicona e polissulfetos. Em 1961, McLEAN ${ }^{106}$ comparou a precisão relativa de reprodução das siliconas em relação ao polissulfeto. Os testes físicos foi conduzido por um período de um ano, onde a atenção particular recaiu sobre a vida útil dos materiais, durante este período de tempo. Os testes para ambos os tipos de materiais deram ênfase; a) à estabilidade dimensional (contração de polimerização e coeficiente térmico de expansão linear), b) à vida útil (consistência da pasta, testada mensalmente por um ano), c) ao tempo de polimerização, após armazenagem prolongada em várias temperaturas, d) à superfície da moldagem (borda da superfície, evolução do gás e porosidade superficial). $\mathrm{O}$ autor verificou ser a estabilidade dimensional influenciada pela contração de polimerização e pelo coeficiente de expansão térmica; sendo que a contração da silicona é influenciada pela variação da temperatura existente entre a boca e o meio ambiente. Para compensar esta variação, recomenda que o molde deve ser colocado em uma incubadora a $37^{\circ} \mathrm{C}$. Em se tratando da percentagem de deformação das mercaptanas, esta é dobro do das siliconas; sendo que a mercaptana permaneceu inalterada por um período de estocagem de um ano. Variações significantes não foram observadas no tempo de polimerização, quando submetido à temperaturas de $3,3 \pm 1^{\circ}$ $\mathrm{C}, 20 \pm 3^{\circ} \mathrm{C}$, e $32 \pm 1^{\circ} \mathrm{C}$, (observada a cada mês), pois, o tempo de trabalho permaneceu constante; concluiu ainda, que estes materiais não são satisfatórios; mas as mercaptanas, por apresentarem um tempo de trabalho maior do que as siliconas, são mais indicadas para moldagens múltiplas.

Uma grande variedade de materiais de moldagem à base de silicona tem sido fabricado nos últimos seis anos. A maioria destes produtos tem sofrido defeitos quanto à sua qualidade de manipulação ou de estocagem; tais fatos têm limitado seu 
uso. Propriedades indesejáveis destas siliconas incluem: pouco tempo de trabalho, curta vida útil, produção de gás durante a polimerização; perda de detalhes superfícies da moldagem; propriedades elásticas pobres e dificuldades na produção de corpos elétroformados. MILLER; MYERS ${ }^{110}$, em 1962, pesquisaram as propriedades físicas quanto ao tempo inicial e final de polimerização, à elasticidade, à consistência, à compatibilidade com os materiais para troquel, à vida útil e qualidades elétroformadoras. Os materiais de moldagem empregados foram; Elasticon, R\&R Silicona, Whip-Mix Silicona, Syring Elasticon, Jelcone, Impraline e Siligel. Para eliminar as variações na proporcionalidade dos materiais, foi usada uma seringa Luer para proporcionar o catalisador e a pasta base foi dosada de acordo com o comprimento. As dosagens foram feitas de acordo com as orientações dos fabricantes. Os autores concluíram que: 1) o tempo inicial de polimerização variou de 2 a 7 minutos; 2) o tempo final de polimerização variou de 4 a 11 minutos, na temperatura e umidade relativa ambiente; 3) os produtos com menor tempo de polimerização tiveram menor influência da temperatura ambiente do que os com maior tempo de polimerização; 4) as propriedades elásticas dos materiais foram satisfatórias, e a percentagem de distorção e deformação permanente foram dentro dos valores especificados para materiais de moldagem à base de borracha; 5) todos os materiais empregados no teste foram compatíveis com o gesso dental usado; 6) armazenagem a $60^{\circ} \mathrm{C}$, por uma semana, produziu alterações em um produto que foi similar àquela vista em outra amostra do mesmo produto, armazenado sob estufa por 3 minutos.

Segundo CUSTER et al. ${ }^{55}$, 1964, existem opiniões conflitantes quanto ao uso, à precisão e às alterações dimensionais dos materiais de moldagem à base de silicona. Os fabricantes têm ciência deste problema, razão pela qual as propriedades indesejáveis que estes materiais mostravam inicialmente terem sido sanadas. Os autores avaliaram a precisão e a estabilidade dimensional destes materiais e técnicas para seu uso. Preparos MOD e totais foram feitos em um pré-molar e em um molar, respectivamente, e, a partir destes foi feita uma fundição em prata para se confeccionar 
um modelo padrão, moldagens (Dou-Dent 500, Jelcone, Permlastic, Jeltrate, Alginato S. S. Withe ), foram feitas com moldeiras de estoque e individuais, sendo vazadas imediatamente, após 30 minutos, 1, 4 e 24 horas, das moldagens terem sido realizadas. A precisão e estabilidade dos materiais pesquisados mostraram serem altamente aceitáveis; porém, a manipulação e a técnica para o uso destes materiais afetaram definitivamente a precisão de reprodução. As alterações e propriedades desfavoráveis, existentes nos primeiros materiais disponíveis, não estão agora muito aparentes.

Uma técnica de moldagem foi apresentada por $\mathrm{CAREY}^{36}$ em 1966, o qual julga ser mais vantajosa à que emprega seringa para injetar o material de moldagem fluido ao redor do dente preparado. Este sugere que se use uma moldeira parcial carregada com o material denso, para a primeira moldagem, após a polimerização, o molde é removido e para evitar a pressão hidráulica produzida na reinserção do molde, para a segunda moldagem com o material fluido, deve-se fazer cortes em forma de V, na região cervical do primeiro molde, os quais servirão como meios de escoamento para o segundo material, evitando-se assim, a pressão e a conseqüente distorção do molde. O emprego desta técnica permite uma camada de material de moldagem de consistência fluida em torno de 2 à $3 \mathrm{~mm}$ de espessura. Alguns cuidados devem ser tomados no emprego dessa técnica; $1^{\circ}$ ) evitar a movimentação da moldeira até a completa polimerização do material, $2^{\circ}$ ) usar pouco material fluido no reembasamento, $3^{\circ}$ ) remoção das áreas retentivas (alívio) no primeiro molde, o que permitirá o assentamento correto no momento do reembasamento, e $4^{\circ}$ ) esperar a polimerização por completo do material fluido.

A deformação permanente em relação ao tempo de polimerização e um método para determinar a estabilidade dimensional dos elastomeros; polissulfeto, silicona e poliéter, foram analisados por CHONG; DOCKING ${ }^{41}$, em 1969. Estes concluíram que o tempo de polimerização específico para o uso clínico, particularmente, para o polissulfeto, não corresponde à realidade, propuzeram, por 
conseguinte, a manutenção da moldeira, por um tempo maior, na boca do paciente. Com relação à deformação permanete, a silicona e ao poliéter, são relativamente menores do que a do polissulfeto, enquanto a estabilidade dimensional deste e a do poliéter, mostraram menores alterações do que a silicona.

ASTIZ; LORENCKI ${ }^{15}$, em 1969, relataram que muitos são os trabalhos realizados com resturações de ouro, confeccionadas diretamente sobre um modelos e que se estes, não forem fiéis em reproduzirem os detalhes do preparo dental, poderão levar à uma desadaptação da restauração. $\mathrm{O}$ enceramento e a posterior fundição, podem estar adaptadas ao modelo, porém, o mesmo não ocorrerá na boca. Enfatizam ainda que todos os materiais, para a confecção modelos, sofrem alguma alteração dimensional, sendo preferivel o material que apresente a menor quantidade de alterações. Os autores mediram as alterações dimensionais de oito tipos de materiais para modelos, obtidos de moldes, de silicona de consistência pesada, de um troquel metálico. Concluíram que: a precisão de adaptação de uma fundição dental depende de diversos fatores conhecidos e desconhecidos, e que, a precisão de reprodução do modelo é um dos conhecidos. Seus resultados mostraram que gesso não adulterados são os mais precisos que outros materiais.

O resultados das pesquisas científicas dos materiais elastoméricos de moldagem, durante as duas últimas décadas, têm estimulado seu uso em grande escala, na prática dental. Com a introdução por Sears (1937), da técnica do hidrocolóide reversível, abriu-se caminho para uma nova era na odontologia. BASSETT et al. ${ }^{21}$, em 1969, analisando os procedimentos clínicos indiretos, compararam certos fatores manipulativos no uso de 3 tipos de materiais de moldagem: Surgident - hidrocolóide reversível, Elasticon - silicona e Permlastic - polissulfeto, relatando o grau de precisão que pode ser obtido. Foram feitos, para cada teste, 12 moldes e os respectivos modelos para cada tipo de material de moldagem, sendo que os moldes com silicona e polissulfeto, procuraram ser obtidos na temperatura da boca; enquanto que os moldes 
foram vazados, em grupo, após 10 minutos \pm 5 minutos, ao fim de 60 minutos e com 8 horas. Concluíram que: 1) o modelo mais preciso foi obtido no vazamento dentro de 15 minutos, quando observados os cuidados e princípios de vazamento; 2) os materiais mostraram contínua distorção, quando estocados por muito tempo; 3) silicona e polissulfeto mostraram maior precisão, quando do uso de moldeiras que permitiam uma espessura de material em torno de $3 \mathrm{~mm}$; 4) a distorção do polissulfeto e da silicona foram maiores do que a do hidrocolóide reversível, quando estocados por 60 minutos.

A técnica de moldagem de reembasamento corretiva, usada por alguns dentistas com um aparente sucesso clínico, consiste na remoção de todas as retenções e superfícies interproximais da primeira moldagem defeituosa, de tal modo, que a moldagem possa ser reassentada com facilidade. A moldagem é, neste caso, completada com um material de corpo leve e é reposicionada para a moldagem final. PODSHADLEY et al. ${ }^{123}$, em 1970, compararam duas técnicas: da dupla moldagem e a do reembasamento, utilizando mercaptana, em ambos os casos para determinar a precisão dos modelos de gesso obtidos. Foi utilizado um troquel de aço inox, como padrão, reaquecido à $36^{\circ} \mathrm{C}$., sendo as moldagens feitas de acordo com as orientações dos fabricantes. Foi usado um microscópio, para comparar os modelos de gesso ao padrão. Os resultados demonstraram que: os modelos produzidos por ambas as técnicas de moldagem foram, no geral, maiores do que o troquel-padrão; os modelos produzidos pela técnica de reembasamento foram ligeiramente menores do que aqueles produzidos pela técnica de não reembasamento. Os modelos produzidos pela técnica de reembasamento duplicaram mais precisamente o troquel-padrão.

STACKHOUSE JR. ${ }^{141}$, em 1970, realizou um estudo para avaliar a precisão dos elastômeros em relação às alterações dimensionais sofridas após a sua remoção da boca. Salientou ser clinicamente importante o inter-relacionamento gesso/material de moldagem. Para a parte experimental utilizou um modelo de aço com troquéis metálicos, empregando as seguintes técnicas de moldagem: 1) reembasamento (material 
pesado + leve); 2) moldeira perfurada; 3) dupla mistura simultânea. Avaliou ainda o efeito do retardo no vazamento, em 30 minutos, 1,30 horas e 2,30 horas, os troquéis de gesso(Vel-Mix), obtidos, foram analisados posteriormente em microscópio. Observou que houve a tendência dos troquéis tornarem-se menores e com diâmetro reduzido nos moldes obtidos com silicona, justificando que esse fato pode estar ligado à diminuição da temperatura do molde retirado da boca e/ou polimerização contínua do material com evaporação de elementos voláteis. Com relação à mercaptana, houve perda de uniformidade e tamanho dos troquéis de gesso obtidos, devido à característica de pequena recuperação elástica desse material. A técnica em que se empregou a moldeira perfurada, resultou em troquéis de gesso com comprimentos e diâmetros menores. Para todos os materiais, onde de tempo de vazamento foi retardado, obteve-se modelos menores em altura mas com diâmetros maiores. O vazamento sucessivo implicou em alterações dimensionais maiores dos troquéis de gesso, acima da especificação $\mathrm{n}^{0} 19$ da Associação Dentária Americana.

Os fabricantes de artigos odontológicos têm desenvolvido materiais elásticos de moldagem, com precisão aceitável no uso clínico. Em 1970, estudando o efeito da influência retenção das moldeiras sobre a distorção de 4 materiais elastomérico de moldagem (Hidrocolóide reversível, Hidrocolóide irreversível, Polissulfeto e Silicona), MITCHELL; DAMELE ${ }^{111}$ concluíram que: todos os materiais de moldagem mostraram-se clinicamente estáveis; as características das moldeiras têm influência sobre as distorções dos materiais de moldagem testados. As moldagens feitas em moldeiras perfuradas, apresentaram maior distorção do que as de retenção nas bordas, sendo que as distorções foram menores quando as retenções eram lubrificadas.

Em 1971, CALOMENI ${ }^{35}$, descreveu uma técnica simplificada de reembasamento, permitindo a obtenção de moldes precisos e nítidos para a confecção de prótese fixa e, consistia na confecção de uma moldeira individual em resina acrílica autopolimerizável, de um modelo obtido através de molde de alginato, sobre o qual era 
feito um alívio de 3 a 4mm. Após o acabamento da moldeira, um adesivo para borracha era aplicado em toda a sua superfície interna, e deixado secar por 10 minutos, para posterior carregamento da moldeira com material de moldagem massa ou regular, levando-se a seguir o conjunto à boca. Aguardava-se a polimerização do material e a moldeira era removida da boca e aliviava-se as áreas retentivas deste primeiro molde. Uma fina camada de material fluido era colocado sobre e ao redor do dente preparado, após o que, a moldeira era levada em posição com firmeza e mantida em posição sobre pressão constante para prevenção de movimentos, até a polimerização do material. Esta técnica, segundo o autor, reduzia consideravelmente a ocorrência de falhas ou defeitos no molde, conferindo-lhes bons detalhes.

Embora os dentista empreguem técnicas variadas, para fazer uma moldagem com mercaptana, a da dupla moldagem tem sido largamente utilizada. PODSHADLEY et al. ${ }^{124}$, 1971, estudaram a precisão dos troquéis de gesso, confeccionados através de moldagens com mercaptanas pela técnica do realinhamento, comparando-a à da dupla moldgem. A técnica do realinhamento (reembasamento) consistia em fazer uma moldagem preliminar, convenientemente aliviada para que fosse facilmente reposicionada na boca (às vezes, somente alívios nas áreas interproximais eram necessários ), quanto então esta moldagem era reembasada com material de consistência fluida e reposicionada na boca para a moldagem final. Foi construído um troquel-padrão em aço inox, que simulava o preparo de duas coroas intra e extra coronal. Dez troquéis de gesso foram produzidos, a partir do emprego de cada uma das técnicas de moldagem. Os materiais foram dosados e manipulados de acordo com as orientações dos fabricantes. Antes de se executar a moldagem, o troquel-padrão era pré aquecido à $98^{\circ} \mathrm{F}$. Depois de pronto, esta moldagem foi deixada em uma incubadora por 15 minutos à temperatura de $98^{\circ} \mathrm{F}$. Imediatamente, após ter sido retirados da incubadora, os modelos foram vazados, com gesso Silky-Rock e deixados para a presa, por 30 minutos, antes da sua separação do molde. Para as moldagens produzidas pela técnica do realinhamento, foram adicionadas ao troquel-padrão, placas de cera de 1-1,5 
$\mathrm{mm}$ de espessura para produzir um alívio, o qual permitia de 2 a $6 \mathrm{~mm}$ na espessura do material de moldagem. As dimensões horizontais de cada troquel foi medida em um microscópio de leitura micrométrica. Os resultados mostraram que os troquéis produzidos por ambas técnicas foram, no todo, maiores do que o troquel-padrão, mas o produzido pela técnica do reembasamento foi levemente mais preciso do que o da técnica da dupla moldgem.

Segundo ASGAR ${ }^{13}, 1971$, os vários tipos de materiais de moldagem, hoje usado na odontologia, foram desenvolvido no(s) último(s) século(s). Cera, gesso, molde composto, pasta de óxido de zinco e eugenol, hidrocolóide reversível, hidrocolóide irreversível, polissulfeto, e silicona são alguns dos materiais empregados atualmente para a confecção de moldagem, de várias áreas do arco dental, para diferentes propósitos. Dentre estes materiais, o hidrocolóide reversível, o hidrocolóide irreversível, o polissulfeto e as silicona são capazes de exibirem comportamento elástico; razão pela qual tratam-se dos materiais mais usados extensivamente na odontologia restauradora.

A precisão dimensional dos materiais usados na fabricação de peças fixas ou removíveis representa, tanto para o dentista como para o cientista de materiais dentários, um dos maiores desafios. $\mathrm{BROWN}^{33}$, 1973, analisou as origens das imprecisões que podem resultar do uso de materiais elastoméricos de moldagem, tais como: efeitos térmicos, absorção de água durante a moldagem, efeitos da recuperação elástica, polimerização continuada, perdas de constituintes voláteis, absorção de água durante a estocagem, expansão de presa dos gessos e expansão da superfície de moldagem. Foram feitos experimentos com hidrocolóide e grupos de elastômeros. A comparação realizada entre as diferenças dimensionais de modelos de gesso vazados em intervalos de uma hora e uma semana, após a moldagem de troquéis-padrão de metais, com e sem retenção - e os materiais, acima citados, de ambos os grupos, possibilitou que se analisasse, não só a precisão dimensional, mas a estabilidade dos 
mateiras. $\mathrm{O}$ autor concluiu que: a) o polissulfeto e o poliéter eram menos afetados pela força da remoção de áreas retentivas; b) durante a estocagem, os polissulfetos eram menos susceptíveis para absorção e perda do solvente, já o poliéter necessitava ser conservado em ambiente seco para manter sua precisão; c) as siliconas e o hidrocolóides não mantêm sua precisão durante longas períodos de estocagem.

A deformação permanente de 14 materiais de moldagem elastoméricos em uso na Grécia, foi estudado por KALOYANNIDES ${ }^{84}$, em 1973. Os resultados obtidos foram comparados a uma amostra de borracha, de vulcanização conhecida. A avaliação foi feita com 10 minutos, 24 e 48 horas, após a manipulação dos materiais. O autor, concluiu que as siliconas e os poliéteres mostraram menores deformações permanentes do que as mercaptanas nas avaliações de 10 minutos, após a estocagem.

A precisão dos materiais de moldagem podem ser afetadas por vários fatores, os quais devem receber atenção especial. Entre estes estão: o tipo de material empregado, a espessura do material de moldagem entre o dente e a moldeira, o tipo de adesão entre o material e a moldeira e o tempo de vazamento do molde. Outros que devem ser levados em consideração, por terem influência na precisão da estabilidade da moldagem, são; a viscosidade do material de moldagem e o tempo em que este material permanece em contato com os tecidos bucais. Se a viscosidade do material é muito baixa, este escoará para fora da moldeira ou não entrará em íntimo contato com a região a ser moldada; por outro lado, se tem uma viscosidade muito alta, deformações elásticas podem ser induzidas, causando distorções ou moldes imprecisos. REISBICK ${ }^{127}$, em 1973, estudou a alteração dimensional de 3 tipos de materiais de moldagem, (silicona, polissulfetos e o hidrocolóide reversível) tendo usado materiais de baixa e de alta viscosidade, para cada tipo de material. Concluiu que: a) a estabilidade e a fidelidade, produzidas pelos materiais de alta e baixa viscosidade, mostraram o mesmo grau de distorção para todos tipos utilizados; b). a estabilidade, após uma hora de estocagem, mostrou que, os elastômeros são mais estáveis do que os hidrocolóides; c) de acordo 
com os valores calculados, da viscosidade, demonstrou que, a rápida velocidade de polimerização da silicona e a rápida velocidade de geleificação do hidrocolóide, podem diminuir a estabilidade e a precisão, devida à liberação de deformação latente.

Estudando as propriedades dos materiais de moldagem, COMBE; GRANT $^{47}$, em 1973, afirmaram que estes materiais deveriam ter certas propriedades, para o seu emprego na odontologia moderna. A precisão e estabilidade dimensional são duas características importantes, citadas, visto que as restauração ou aparelhos, fabricados no laboratório dental, não podem ser mais precisos do que a moldagem usada na sua produção. São importantes ainda, a vida útil de armazenamento do material, o tempo de polimerização e a aceitação pelo paciente, isto é, o material não pode ser tóxico ou irritante, de sabor e odor agradável. Os autores ressaltam ainda que as imprecisões dimensionais são induzidas, ou na manipulação ou por técnica e materiais de baixa qualidade, nos seguintes estágios: a) na inserção do material dentro da boca, este deve ser capaz de deformação plástica; b) durante a polimerização, esta não deve ser acompanhada de alterações dimensionais; todavia, na prática, isto não ocorre e, em se tratando de reações, envolvendo cristalização (presa do gesso), são usualmente acompanhadas de expansão; c) no deslocamento da moldagem, durante sua remoção da boca, deve haver adequada adesão do material de moldagem à moldeira; d) memória elástica deste; e) antes da modelagem do modelo ou molde, nenhuma alteração dimensional deveria ocorrer entre a remoção do molde da boca até o vazamento; f) os materiais de moldagem deveriam ser compatíveis com os materiais do modelo ou do troquel. Concluem que a seleção dos materiais deveria ser indicada pelas condições clínicas e pelas preferências individuais.

Para COLLARD et al. ${ }^{46}, 1973$, a precisão dos materiais odontológicos de moldagem são essenciais. Estes materiais são freqüentemente empregados para se obter uma reprodução negativa dos tecidos orais e estão sujeitos aos stress, quando da sua remoção da boca. Retenções, ângulos e espaços interproximais influenciam na 
deformação elástica destes materiais e fogem ao controle do dentista. Por outro lado, certas passos podem ser controlados: desenho da moldeira, quantidade do material de moldagem e direção da remoção da moldagem da boca. Os autores buscaram estudar se o efeito do desenho da moldeira, a espessura do material de moldagem, e o grau de retenção, produziria stress no material, quando da remoção do molde. Concluíram que: 1) para retenções que variavam de 0 a $10 \%$ com 6 a 9 mm no volume do material de moldagem, o stress desenvolvido na mercaptana foi que igual tanto para moldeira flexível quanto para a moldeira rígida, 2) Para graus de retenções acima de 10\%, uma combinação de moldeira flexível e a espessura do material tornou-se, progressivamente, mais importante para a diminuição dos stress durante a remoção do molde, e que, devem ser melhor analisados o aumento no grau de retenção acima de $10 \%$ e as diferenças entre as configurações da moldeira e volume.

Ao comentar sobre um novo material de moldagem, o poliéter, BAROLET; DESAUTELS ${ }^{20}$, em 1974, afirmam que este é limpo, inodoro, tem um gosto agradável, de fácil manipulação, mas que o seu tempo de trabalho é muito curto; é preciso e razoavelmente rígido, podendo apresentar alguma dificuldade para sua remoção da boca. Devido ao seu alto coeficiente de expansão térmica e pela sua grande afinidade com absorção de água., pode apresentar imprecisões. O uso de solventes para diminuir sua viscosidade, diminui a sua rigidez e sua estabilidade dimensional.

Várias pesquisas sobre as propriedades e características dos materiais de moldagem tem sido realizadas. Inúmeros relatos têm se preocupado particularmente com a estabilidade dimensional e precisão destes materiais. Enquanto alguns dos materiais mais populares têm sido extensivamente estudados, outros, disponíveis no mercado, não recebem a atenção adequada. HENRY; HARNIST ${ }^{76}$, em 1974, pesquisaram 14 materiais de moldagem para compararem a estabilidade dimensional linear e sua respectiva precisão. Moldeiras de resina foram padronizadas e receberam stops. Para promover espessura uniformes, nos materiais, foram utilizadas as técnicas 
de moldagem de simples e de dupla mistura. e, neste caso, os materiais foram manipulados de acordo com as instruções dos fabricantes. Os moldes foram vazados com gesso, na proporção de pó/água de 100/24, e manipulados a vácuo por 30 segundos; os modelos foram deixados descansar por 24 horas, antes da separação, e medidos após 7 dias. Os modelos obtidos de diferentes moldagens, demonstraram mudanças dimensionais durante o envelhecimento. Já as moldagens de silicona, correspondentes, apresentaram modelos de alteração dimensional horizontal negativa enquanto que as moldagens de dupla-mistura de polissulfetos e siliconas produziram modelos de alterações dimensionais horizontal positiva. Ressaltaram, ainda, que as moldagem de mistura simples de poliéter resultaram em modelos de alteração dimensional horizontal com um pequeno aumento. A comparação entre os materiais à base de silicona e à base de poliéter demonstraram, menores mudanças dimensionais do que os outros materiais. Os melhores resultados foram conseguidos quando os moldes foram vazados um tempo menor, após a moldagem.

As siliconas, os polissulfetos e os poliéteres, devidos às suas qualidade borrachóides são usualmente chamados de materiais elásticos. Tais materiais são capazes de reprodução precisas e são clinicamente populares. Em 1974, GOLDBERG $^{69}$, pesquisou as propriedades visco elásticas de 9 siliconas, um polissulfeto, e um poliéter, usando para tanto o teste de deslocamento, onde a força é medida em relação ao tempo sobre stress constante. Concluiu que estes materiais demonstram comportamentos visco elásticos lineares, durante a deformação, sendo que a deformação permanente nestes materiais resulta tanto da falta de recuperação do componente elástico de deformação quanto do fluxo de viscosidade. O poliéter e uma marca de silicona se aproximaram mais do comportamento elástico ideal. Esta característica é descrita como uma mudança dimensional mínima, devido ao stress encontrado durante a manipulação, a separação e a estocagem do molde. As siliconas, em geral, exibiram menos deformação elásticas do que o polissulfeto. 
Os elastômeros são polímeros que exibem grande e reversível extensibilidade à temperatura ambiente; assim, podem ser esticados, no mínimo de $100 \%$, que rapidamente retornam às suas dimensões originais, logo que a carga é retirada. As características estruturais dos elastômeros, aqui superficialmente discutidas, fazem prever que a remoção do molde de superfície retentiva possa promover contração, devido à liberação de tensões induzidas. E, qualquer que seja a causa da contração, sempre a distorção do molde ocorrerá. SANSIVIERO et al. ${ }^{130}$, em 1974, estudando a reprodução de pormenores mais delicados, verificaram a precisão dimensional dos modelos de trabalho, obtidos através de três marcas comerciais de silicona: Optosil/Xantopren, Citricon e Silicomold e de três marcas comerciais de gesso pedra: Vel-Mix, Silky-Rock, Indic-Die-Stone. Foram feitas moldagens de troquéis metálicos, à temperatura de $37^{\circ} \mathrm{C}$ para se avaliar as diferenças que ocorriam entre os modelos, obtidos por meio de medidas efetuadas em microscópio comparador, confrontando-as com a dos troquéis padrões. De acordo com os materiais utilizados e dentro das condições experimentais observadas, os autores deduziram que: a) os modelos de trabalho não reproduzem, satisfatoriamente, os pormenores mais delicados dos preparos cavitários; b) a precisão dimensional dos modelos de trabalho não se situa dentro dos limites de tolerância de $\pm 0,2 \%$.

O elevado grau de contração é a maior desvantagem das siliconas, como material de moldagem. Para superar esta desvantagem, uma técnica de moldagem única com preenchimento de pouco material de densidade regular tem sido desenvolvida. Entretanto, o controle da contração é limitado, pois a necessidade de utilização de muito material é dificultada devido à alta densidade do mesmo para a utilização da seringa. Em 1974, FUSAYAMA et al. ${ }^{67}$, desenvolveram uma nova técnica chamada de moldagem única laminada. Segundo esta técnica, os material fluido e denso são manipulados ao mesmo tempo, sendo o material fluido "laminado", em uma fina camada, por sobre a superfície do denso, que carregou a moldeira, sendo imediatamente levado à boca. A proposta desta laminação é evitar o contato do material denso com o 
preparo, por tornar áspera a superfície do gesso. A densidade do material pesado também orienta o fluido dentro do sulco gengival e dos detalhes do preparo sem o uso da seringa, ainda que esta seja, algumas vezes, empregada nos preparos intracoronários. Neste estudo, os autores buscaram avaliar a precisão dos modelos de gesso obtidos por esta técnica que é comparada a outras três: 1) técnica da mistura única; 2) técnica da dupla mistura sem alívio e 3) técnica da dupla mistura com alívio. Concluíram que a técnica da moldagem única laminada, clinicamente a mais simples, foi capaz de produzir modelos de gesso com adequada precisão e reprodutibilidade superficial suficiente.

BELL; FRAUNHOFER $^{22}$, em 1975, fizeram um revisão de literatura a respeito da correta utilização dos materiais de moldagem elastoméricos, a fim de se obter a maior precisão nas moldagens. Esta revisão possibilitou-lhes estabelecer as seguintes recomendações: 1) acrescer, em 50\%, o tempo de polimerização estipulado pelo fabricante; 2) deve-se preferir, sempre que possível empregar moldeiras individuais às de estoques, pois a moldeira deve permitir uma espessura uniforme de material, cuja espessura desejável é de 2-4 mm, e as moldeiras individuais deveriam ser rígidas; 3) o molde deveria ser deixado em repouso por 30 minutos, para permitir a recuperação elástica antes do vazamento. Tal observação é particularmente importante para as siliconas, todavia, se o atraso é inevitável, o uso do poliéter será mais estável sobre longos períodos, quando estocado sob umidade; 4) há poucas diferenças entre a técnica de dupla mistura e a de reembasamento; 5) o segundo vazamento é sempre mais pobre do que o primeiro, sendo que as margens das coroas deveriam ser definidas no primeiro vazamento; 6) a umidade ou contaminação do material acelera o tempo de presa; 7) a umidade ambiental não afeta o tempo de presa do material e é um importante fator na precisão dos modelos de gesso, principalmente se a moldagem foi feita um certo tempo antes do vazamento; 8) em condições de alta umidade o material de eleição deveria ser do grupo polissulfeto, cuja polimerização é dirigida por dióxidos; 9) moldagens com poliéteres nunca deveriam ser estocadas em ambientes de alta 
umidade; 10) estocagem de siliconas, em condições úmidas, parecem prevenir a perda de seus constituintes voláteis, e a contração de polimerização é compensada pela absorção de água. Estes materiais não devem ser armazenados em lugares muito úmidos ou secos. Os cuidados com a manipulação destes materiais são tão ou mais importantes do que o material ou a técnica em si.

STACKHOUSE JR. ${ }^{142}$, em 1975, citou os três tipos básicos de testes para avaliação dos materiais de moldagem: 1-testes lineares e geralmente unidimensionais que analisam o material em si; 2- testes que avaliam modelos a partir dos materiais de moldagem; 3- métodos onde o desempenho do material de moldagem é avaliado pela adaptação de coroas padrões em troquéis de gesso obtidos de troquéis padrões. O autor avaliou, entre as diferentes condições estabelecidas, a adaptação de restaurações fundidas padrões (totais e parciais) em modelos de gesso Vel-Mix que foram obtidos a partir da moldagem, com diferentes elastômeros, de dentes naturais preparados, em comparação à adaptação de um anel de aço sobre troquéis de gesso obtidos de um troquel de aço inoxidável de forma tronco-cônica. Os testes laboratoriais, consistindo de uma combinação de preparos em dentes naturais/fundições padrões e de troquel metálico padrão /anel metálico, foram efetivos para demonstrar o grau de variação e de imprecisão dos materiais de moldagem.

MANSFIELD; WILSON $^{96}$, em 1975, estudando a estabilidade dimensional de 3 tipos de materiais elastoméricos, para moldagem, descreveram uma técnica, onde as amostras eram submetidas às mudanças de temperatura, que comummente, ocorrem na boca. Concluíram que nos três primeiros minutos acontece a contração térmica ,e a seguir, a de polimerização, sendo que a média geral de contração, após 6 horas, foi de $1,2 \%$ para os polissulfetos; $1,5 \%$ para as siliconas e de $1 \%$, para o poliéter.

As propriedades físicas dos materiais de moldagem - polissulfetos (Tipo I) e siliconas (Tipo II) - têm sido intensamente investigados. Sua precisão tanto quanto sua 
estabilidade, para o registro de detalhes superficiais, são comparáveis, Os polissulfetos possuem uma maior vida útil e uma maior estabilidade para vazamentos tardios do que as siliconas. Os polissulfetos são os melhores fornecedores de modelos precisos, devido à sua estabilidade dimensional superior. As siliconas são de mais fácil manipulação do que os polissulfetos, propiciando a produção de uma mistura mais limpa. A polimerização também é mais rápida nas siliconas, beneficiando a moldagem, pois o molde pode ser mais cedo removido. O menor tempo de vida útil e a produção de gaz hidrogenados durante a polimerização, nas primeiras siliconas, tem sido corrigidos. A desvantagem de ambos os elastômeros é o fato de que a espessura de material de moldagem, entre a moldeira e o dente, tem de ser cuidadosamente controlada. Os estudos indicam que esta espessura deve ser de 2 a 4 mm. Em 1975, REISBICK; MATYAS $^{128}$ avaliaram a precisão dos modelos de moldagens, empregando os novos sistemas de siliconas, usando em seus estudos comparativos elastômeros do Tipo I e Tipo II. Moldagens de um troquel metálico, representando uma prótese fixa com dois pilares, foi confeccionadas em metal, no qual se ajustava perfeitamente um gabarito. Tais moldagens feitas com o uso de moldeiras de estoque e moldeiras individuais; sendo que as moldeiras individuais forneciam $2 \mathrm{~mm}$ na espessura de material de moldagem, enquanto as de estoque compreendiam um caixa metálica que se assentava na base do troquel. Antes das moldagens, adesivos eram aplicados nas moldeiras. Foram nove os elastômeros usados no trabalho: Optosil/Xantopren, Citricon, Coltokit, Coltex, Coltex-S, Xantopren, Citricon wash, COE-flex e Omniflex. Os moldes foram vazados, imediatamente após sua remoção com gesso Vel-Mix, sendo todos os modelos removidos após decorrido 1 hora do vazamento e deixados para secar por 7 dias. $\mathrm{O}$ gabarito foi posicionado sobre cada modelo, com uma força de uma libra; e a distância do topo do pilar até a base superior do gabarito foi medida, empregando uma média aritmética, derivada de três medidas, foi determinada para cada pilar. Repetidas medidas produziram um padrão de erro de 0,006mm. Os autores concluíram: a) que os materiais 1, 2 e 5 apresentaram ser mais favoráveis; b) o sistema Optosil/Xantopren forneceu boa precisão, tanto quanto baixa variabilidade; todavia, este material tende a 
separar as camadas, quando de sua remoção rápida de áreas retentivas; c) o Citricon mostrou ser um produto de fácil manuseio e forneceu uma mistura uniforme e consistente, tanto quanto o tempo de trabalho; d) o Coltene foi o menos preciso e mostrou outras propriedades inaceitáveis; e) alguns modelos apresentavam superfícies com grande porosidades, características de produção de gazes durante a polimerização.

Para GUIDI et al. ${ }^{71}$, 1976, o uso de elastômeros à base de silicona ou de polissulfeto, na clínica odontológica, são cada vez mais freqüentes. Os autores compararam entre si modelos obtidos a partir de moldes de elastômeros de silicona ou polissulfeto, em moldagem, com anel de cobre, dupla (fração com a consistência de massa + porção fluida) ou simples (porção fluida), porém sempre unitária, representada por um preparo padrão para coroa total e variando-se a espessura do material. As moldagens foram feitas de troquéis padrão de aço, empregando-se várias marcas de elastômeros, quer à base de borracha quer à base de silicona. Os materiais foram dosados e manipulados segundo as orientações técnicas dos fabricantes. Os resultados obtidos demonstraram que o fator marca foi altamente significante, o material ColtexColtoflax foi o que melhor se comportou tanto no estudo individual como nas interações. O fator tipo foi altamente significante, a moldagem dupla apresentou melhores resultados do que a simples em todos os casos, com exceção dos materiais Permlastic e Coltex-Coltoflax que apresentaram resultados estatisticamente iguais. $\mathrm{O}$ fator tamanho foi estatisticamente significante, o anel grande foi melhor do que o pequeno apenas na marca Silicomold.

Observações clínicas indicaram que certos materiais de moldagem podem produzir modelos que contenham um maior número de bolhas de ar do que outros materiais de moldagem, que tenham sido vazados com o mesmo gesso para modelo. LORREN et al. ${ }^{95}$, em 1976, realizaram um experimento para determinar se um antecipado ângulo de contato do gesso com o material de moldagem se aproximava ou se era de 90 graus, pois isto é um fator contribuinte para a formação de bolhas de ar, 
durante o vazamento do molde. Como material de moldagem foram empregados, para este experimento, siliconas, poliéter, polissulfeto e hidrocolóide. Os gessos para modelo, seguiam a Especificação $N^{\circ} 25$ da A.D.A., Tipo IV, de alta dureza. Cada material de moldagem foi formado por uma camada de $8 \mathrm{~cm}$ de diâmetro e $3 \mathrm{~cm}$ de espessura. O material foi deixado para polimerizar sobre duas placas de vidro lisas. Um dispersador de "teflon" volumétrico foi usado para dispersar $2 \mathrm{ml}$ de gesso sobre a superfície dos moldes. Três corpos de prova da mesma mistura de gesso foi feito para cada moldagem. A proporção pó/líquido do gesso foi dosada de acordo com a orientação do fabricante. O gesso era manipulado a vácuo por 20 segundos, e dispersado após 1 minuto, contados a partir do início da mistura e sobre baixa vibração, por 2 segundos, sendo que este tempo e esta freqüência eram os mesmos para todos os corpos de prova. Estes eram deixados por uma hora para a presa final, após o qual eram sulcados com um disco abrasivo, e posteriormente, quebrados nesta região, a seguir os ângulos de contato do meio e fim eram medidos, fornecendo seis medidas para cada corpo de prova. Cada corte foi colocado em um prendedor, e posicionados em um microscópio, e fotografados. Os ângulos de contato foram marcados e medidos com um compasso nestas fotografias. Moldagens foram feitas a partir de um modelo, para demonstrar a possível correlação entre as diferenças observadas nos ângulos de contato e o número de bolhas de ar, no modelo de gesso. Este modelo continha nove preparos para onlays. Três moldagens de cada um dos três materiais foram feitas e vazadas, por um dos autores, de maneira similar ao usado para os ângulos de contato. Após a separação, para cada modelo, foram contadas todas as bolhas na superfície dos dentes preparados. Este estudo evidenciou a existência de diferenças nos ângulos de contato dos corpos de prova do gesso, quando advindos de diferentes materiais de moldagem. Os materiais à base de silicona produziram corpos de prova com maiores ângulos de contato e também com maior número de bolhas de ar. Os ângulos produzidos pelos polissulfetos foram intermediários, em relação aos observados em siliconas e poliéter. Os poliéteres foram os elastômeros que produziram menores ângulos de contato e um menor número de bolhas. Os hidrocolóides apresentaram os menores ângulos de 
contato de todos os materiais. Destas observações, concluíram que, devido às características não "umedecedoras" entre o gesso pedra e os materiais de moldagem à base de silicona, existiu uma maior probabilidade de ocorrência de bolhas de ar, em modelos produzidos nestes materiais, em relação aos modelos provenientes de polissulfetos e de poliéteres.

BELL et al. ${ }^{23}$, em 1976, analisaram o efeito de três condições de umidade relativa ambiental sobre as mudanças dimensionais dos diversos materiais, selecionados para moldagem, a saber : Impregum F (poliéter), Xantopren azul (silicona), Optosil massa (silicona), Unilastic (polissulfeto) e Mim (polissulfeto orgânico). O pesquisa foi dividido em 3 partes: 1) um estudo dos efeitos da umidade ambiental, para verificar alterações dimensionais de materiais que não estavam contidos em moldeiras ou similares; 2) um estudo para determinar se os constituintes dos materiais elastoméricos foram perdidos na atmosfera ou se a umidade da atmosfera foi absolvida pelo material; 3) um estudo dos efeitos da umidade relativa do ambiente, em moldagens feitas com materiais elastoméricos. Os autores verificaram alterações dimensionais em todos os materiais testados, devido à vários fatores: 1) o módulo de elasticidade ou de inflexibilidade afeta a quantidade de alterações dimensionais; 2) a perda dos constituintes voláteis do material de moldagem pode compensar a absorção da umidade atmosférica; 3) talvez o mais importante seja que o material pode continuar sua polimerização, depois de "clinicamente" polimerizado, podendo isto causar contração. Em condições restritas, a contração dos materiais resultará em um aumento do molde; mas, com o uso de adesivos, ocorrerá uma adesão firme do material à moldeira. Consequentemente, a eficiência do adesivo é um fator observado na quantidade de contração dos materiais, contidos em moldeiras ou similares. Em relação às condições ideais de estocagem, para se obter o melhor resultado dos materiais testados, são recomendados os seguintes métodos para cada material: a) Impregum F e Impregum F plus (com solvente), devem ser estocados sobre condições de baixa ou média umidade, todavia, estocagem prolongadas sobre condições de alta umidade deveriam ser evitadas; 
b) obtêm-se resultados mais precisos com Unilastic, quando o material é estocado em ambientes de alta umidade relativa, sendo o menos impreciso nestas condições; contudo, para períodos curtos de estocagem, ambientes com alta umidade relativa é indicado; c) para o sistema Optosil/Xantopren, condições de baixa umidade devem ser evitadas, apesar de que vários corpos de provas deste material produzirem uma grande mudança, quando estocados sobre alta umidade, mas esta expansão é compensada pelo coeficiente de expansão do gesso usado.

Em uma revisão da especificação $\mathrm{N}^{0} 19$, sobre materiais odontológicos de moldagem elastoméricos não aquoso, realizada em 1977 pela AMERICAN DENTAL ASSOCIATION $^{3}$, os materiais de moldagem são classificados como Tipo I, II e III, de acordo com seus comportamentos em relação as suas propriedades elásticas e alterações dimensionais, após a polimerização. Cada tipo ainda é classificado pela sua aparente viscosidade e uso. Esta especificação para os elastômeros é baseada em polissulfetos, polivinilsiloxanos, poliéteres, e outros materiais não aquosos, capazes de reagirem e formarem uma borracha, podendo serem empregados para moldagens. O tempo de mistura é aquele requerido para se fazer uma coloração uniforme e homogênea dos componentes. O tempo de trabalho é contado a partir do início da mistura, até que a aparente viscosidade aumente à níveis definidos para o procedimento padrão. O tempo de polimerização é o tempo transitório, medido desde o início da mistura, quando as propriedades plásticas permitem fazer moldagens, até o momento em que estas propriedades sejam perdidas e as propriedades elásticas do material permitam que este seja removido das áreas retentivas. Em relação à sua compatibilidade com os gesso, o material deverá promover uma superfície lisa, livre de buracos grosseiros e permitir a separação do modelo de gesso. O fabricante determinará o tempo de espera para o vazamento do gesso, se este for maior do que 10 minutos. No final do parágrafo, são descritas notas que tratam de alguns aspectos que não fazem parte das normas, como por ex.; liberação de gazes, que ocorrem em certas formulações, causando superfícies de gesso porosas; a precisão das siliconas de alta precisão (melhoradas), que 
apresentam, como resultados, o desprendimentos de gás, durante a sua reação de polimerização.

Em 1977, CRAIG $^{50}$, comparando as propriedades físicas e mecânicas de materiais de moldagem, à base de borracha (polissulfeto, silicona de condensação, silicona de adição e poliéter) buscou interpretar os seus valores, em termos de aplicações clínicas, e concluiu que: 1) os polissulfetos têm, no geral, um longo tempo de trabalho; uma deformação permanente, um escoamento e uma flexibilidade muito alta e uma baixa alteração dimensional, na polimerização, com propriedades viscosas significantes, além de não serem idealmente elásticos como os outros materiais elastoméricos; 2) as siliconas, polimerizadas por reação de condensação, têm propriedades elásticas superiores, quando comparadas aos polissulfetos; todavia, apresentam um tempo de trabalho pequeno, uma baixa flexibilidade, e alterações dimensionais, significantemente altas, durante polimerização; 3) as siliconas, polimerizadas por reação de adição, têm uma melhor propriedade elástica e baixas alterações dimensionais na polimerização, do que alguns dos materiais de moldagem elastoméricos, contudo, têm um tempo de trabalho moderadamente pequeno, e razoavelmente difícil de se remover da boca; 4) o poliéter tem um curto tempo de trabalho e uma baixa alteração dimensional de polimerização, mas é de difícil remoção da boca, podendo o tempo de trabalho e a flexibilidade serem aumentadas pelo uso do solvente sem sacrificar as qualidade elásticas e das alterações dimensionais.

As classificações dos elastômeros podem ser estabelecidas de acordo com sua composição química, ou segundo COMBE; MOSER ${ }^{48}$, 1978, de acordo com o uso clínico pretendido, observando que diferentes aplicações requerem diferentes variações de viscosidades. Os quatros tipos básicos de materiais são: 1) Material massa (pesado),que funcionam como uma moldeira individual (moldagem preliminar); 2) materiais para moldeiras, estes, relativamente viscosos, são usados para vedamento periférico em moldeiras individuais especiais; 3) materiais de viscosidade regular, 
menos viscosos do que os indicados acima e usados em vários propósitos nos trabalhos de moldagens; 4) materiais fluidos (de baixa viscosidade), que fornecem moldes detalhados, usados em conjunto com os de viscosidade densa.

VALLE $^{148}$, em 1978, avaliou o desajuste cervical de coroas metálicas fundidas com liga áurea, confeccionadas a partir de moldes obtidos de três elastômeros, empregando a técnica do casquete e da moldeira individual acrílica que proporcionavam, respectivamente, 0,5 e $3 \mathrm{~mm}$ de espessura para os diferentes materiais de moldagem. Dois troquéis metálicos, um esquemático e outro que simulava um preparo clínico, foram moldados com uma mercaptana (Unilastic), uma silicona de condensação e um poliéter (Impregum) e vazados com gesso especial, obtendo a seguir o padrão de cera e a fundição de coroas totais. O desajuste cervical no troquel padrão mostrou, para as peças obtidas pela técnica do casquete, uma menor discrepância do que as obtidas com moldeiras individuais, independente do material utilizado. Além disto, observou diferença de comportamento entre os elastômeros quando do uso de moldeiras individuais, o que também aconteceu quando da moldagem com casquetes. Constatou, ainda, a influência do tipo de troquel metálico, sendo que o troquel esquemático, que apresentava maior área superficial e menor inclinação de paredes, originou coroas com maiores desajustes cervicais $(116 \mu \mathrm{m})$ que o troquel clínico $(56 \mu \mathrm{m})$, quando da moldagem com casquetes.

HARCOURT $^{75}$, em 1978, estudando materiais de moldagem, especificamente a pasta ZOE, Alginato, polissulfetos, poliéteres e siliconas, concluiu que para estes materiais: 1) não são recomendado tempo de vazamento, por um período superior a 60 minutos; 2) deveriam ser usadas moldeiras individuais rígidas, pois o uso das mesmas diminuiriam as alterações dimensionais, associadas à espessura do material, além de propiciar uma economia de material; 3) as moldeiras deveriam ter uma boa retenção, quer por furos ou pelo uso de adesivos. 
Com a finalidade de desenvolver um método, capaz de medir as propriedades físicas e mecânicas, durante a polimerização, e para determinar as características precisas de polimerização dos materiais de moldagem elastoméricos, INOUE; WILSON ${ }^{79}$, em 1978, utilizaram um galvanômetro de oscilação, que foi modificado por ele, mas desenvolvido por BOVIS et al. Os materiais usados para este experimento foram uma silicona (Flexicon), poliéter (Impregum) e um polissulfeto (Surflex): todos foram manipulados por 40 segundos., de acordo com as recomendações dos fabricantes, e a uma temperatura de $3 \pm 0,5^{\circ} \mathrm{C}$, quando então era imediatamente transferidos para o instrumento, em uma cabina de ar a $32 \pm 0,5^{\circ} \mathrm{C}$. e deixados polimerizar. O tempo de polimerização dos materiais foi de 5 minutos, para o Impregum; 6 minutos, para o Flexicon e de 9 minutos, para o Surflex.

Em 1978 - pesquisando o efeito da relação base/catalisador, o tempo e a temperatura sobre o módulo de cizalhamento de alguns materiais de moldagem elastoméricos (poliéter, polissulfeto e silicona), INOUE; WILSON ${ }^{80}$ concluíram que os tempos de polimerização do poliéter e das siliconas são menores do que o do polissulfeto; entretanto, a polimerização diminui com o aumento da quantidade de catalisador (ativador), enquanto que o valor do módulo diminui consideravelmente. Salientaram ser preferível, no emprego clínico destes materiais, que o controle do tempo de trabalho e de polimerização seja feito através da mudança na temperatura de manipulação do material de moldagem, e não na relação dos componentes base/catalisador.

São três os tipos de materiais de moldagem geralmente empregados, os polissulfetos, as siliconas e os poliéteres. Tanto que cada material possui suas vantagens e desvantagens, sua seleção depende freqüentemente da preferência pessoal do profissional. Os poliéteres absolvem água, podendo com isto, sofrer alterações dimensionais, sendo ainda relatados alguns casos de alergia. Os polissulfetos possuem odor e gosto desagradável e, tempo de polimerização longo, sendo descartados por 
alguns profissionais devido à estes desvantagens. As siliconas após a sua remoção da boca é inferior aos outros materiais citados, devido a liberação de subprodutos alcoólicos, na reação de condensação, causando uma contração contínua deste material. A despeito de algumas desvantagens dos elastômeros, alguns não podem ser aceitos como materiais de moldagem, podendo não ser empregados em algumas das situações clínicas. Em 1978, McCABE; WILSON ${ }^{102}$, realizaram uma avaliação das propriedades físicas de siliconas, polimerizadas por adição, comparando-as com os polissulfetos e poliéteres. Das propriedades analisadas, tais como; características de polimerização, tensão no assentamento, estabilidade dimensional, e tempo de trabalho, os autores concluíram que a maior vantagem das siliconas de polimerização, por adição, está na sua estabilidade dimensional, pela não formação de subprodutos durante a sua polimerização. Quando comparadas com as siliconas, de condensação, apresentam ainda maior estabilidade dimensional e tempo de trabalho, sendo sua maior desvantagem, a sua baixa resistência ao estiramento em relação as outras siliconas ou polissulfetos, sendo clinicamente este fator detectado como distorção.

INOUE; WILSON ${ }^{81}$, em 1978, desenvolveram um método para avaliar a recuperação elástica de polimerização dos materiais de moldagem elastoméricos. Os autores, através dos resultados obtidos por este método, de mensuração, concluíram que os polissulfetos mostraram uma maior demora na recuperação elástica do que os poliéteres e as siliconas, sendo essa recuperação é menor nos polissulfetos, deteriorando-se com a duração da pressão, confirmando assim, a necessidade da remoção rápida do molde da boca. A partir desses resultados pode-se concluir que o poliéter e a silicona podem ser usados em situações mais exigentes quando comparados com os polissulfetos.

GULLETT; PODSHADLEY ${ }^{73}$, em 1979, realizaram um estudo para analisar o custo, em função do tempo e material, para reembasamento de moldes obtidos com mercaptana em comparação à necessidade de uma nova moldagem. As moldagens 
foram realizadas a partir de um manequim, utilizando o seu arco inferior. Moldeiras individuais de resina acrílica foram confeccionadas para estabelecer um espaço uniforme de 2 milímetros para o material de moldagem. Cada uma das cinco moldagens foi aliviada internamente, com ponta montada para resina acrílica, e pesada após o alívio e o reembasamento do molde. O tempo requerido para este procedimento foi igualmente determinado, assim como para se refazerem as moldagens. Os resultados mostraram uma grande diferença na quantidade de material utilizado para as duas técnicas, sendo requeridos somente $38 \%$ de material para o reembasamento total do molde, ou seja, 35,8 gramas foram utilizados para se refazer a moldagem e 13,6 gramas para o reembasamento, o que resulta em ganho de custo e preservação de qualidade. Com relação ao tempo, observaram que para a técnica do reembasamento aproximadamente $46 \%$ do tempo requerido para se refazer uma nova moldagem foram necessários.

Para se ter um assentamento correto da fundição, os passos desde a moldagem à fundição devem ser precisos, e segundo, EAMES et al. ${ }^{60}$, 1979, estão envolvidos 5 passos nestes procedimentos; moldagem, modelo, enceramento, inclusão e fundição a ouro. O material de moldagem é usado na primeira fase, e alguma imprecisão acarretará em insucesso. Alguns fatores são importantes na escolha do material de moldagem, pelo dentista, tais como; precisão, estabilidade dimensional, tempo de trabalho, tempo estocagem, capacidade de metalização, e sabor. Com esta finalidade, os autores analisaram 34 materiais de moldagem, de 13 fabricantes, para examinarem a precisão e a estabilidade dimensional. Os materiais foram testados de acordo com as especificações $\mathrm{N}^{\mathrm{o}} 19$, da A.D.A, incluindo, um troquel-padrão metálico. A porcentagem da alteração linear negativa foi medida com 30 minutos e 24 horas. Quando o sistema massa foi usado, uma pequena quantidade de fluido foi empregado, para melhorar os detalhes superficiais. Os autores também fizeram moldagens de um troquel metálico, que simulava um preparo, para coroa total. As moldeiras foram fabricadas, permitindo um espaço para o material de moldagem de 2 e $4 \mathrm{~mm}$. Os 
materiais foram dosados e manipulados de acordo com as normas dos fabricantes, sendo deixados polimerizarem em uma bacia com água, à $32 \pm 2^{\circ} \mathrm{C}$, por 3 minutos, acima do tempo recomendado. O vazamento, foi feito a vácuo, com 30 minutos e 24 horas, após a separação do molde. A precisão dos modelos de gesso foi analisada com o uso de um anel metálico, que foi construído sobre o troquel-padrão e, este assentado sobre os modelos de gesso sobre pressão de $250 \mathrm{~g}$, os autores concluíram que o vazamento deve ser o mais imediato possível. Quando vazados imediatamente, alguns dos materiais avaliados, exibiram características similares de estabilidade e, que o dentista deveria basear sua escolha, em outras considerações. Nas situações, que permitem um vazamento imediato do molde, somente os materiais mais estáveis, deveriam ser selecionados.

Um problema, que se apresenta, no emprego das siliconas e polissulfetos como materiais de moldagem, é que devido à sua baixa energia superficial, os torna de difícil compatibilidade com os gessos. Este pobre umedecimento, levam à inclusão de ar na superfície dos modelos e troquéis. NORLING; REISBICK ${ }^{112}$, 1979, pesquisaram se a incorporação de sulfatos não-iônicos nas siliconas e polissulfetos poderiam aumentar seu umedecimento com os gessos fluidos. A intenção era de atingir o grau de umedecimento dos poliéteres. Para tanto, porções iguais de Permlastic, Elasticon, Xantopren, Impregum F foram empregadas segundo as proporção recomendadas pelos fabricantes. Em seguida, no grupo experimental, foram acrescido no material base, sulfactantes não-iônicos, antes da mistura, tanto nos polissulfetos, como nas siliconas. O aumento no ângulo de contato, entre o gesso e o material de moldagem, foram medidos com o auxílio de um microscópio. Os autores concluíram que a mudança do sulfactante mais efetivo, é crítico e difere, não somente entre os tipos de elastômeros, mas também entre as misturas de um mesmo material. $\mathrm{O}$ efeito benéfico, de um ótimo sulfactante, não é reduzido pelo enxaguamento do molde, antes do vazamento. Enquanto o tempo de trabalho das siliconas é aumentado pela adição do sulfactante, o 
do polissulfeto não sofre alterações, mas a precisão dimensional e a deformação permanente são afetadas em ambos os materiais.

MARCINAK et al. $^{98}$, em 1980, avaliaram 4 classes de materiais elastoméricos de moldagem ( polissulfeto, poliéter, silicona e agar-agar), com a finalidade de verificar a estabilidade dimensional, em função do tempo de estocagem, antes do vazamento do molde. Para aproximar o experimento das condições clínicas, utilizaram 2 incisivos centrais, montados em um bloco de resina acrílica, simulando a posição natural dos dentes na boca, aplicaram uma camada de $3 \mathrm{~mm}$ de cera sobre os dentes, e moldagens foram feitas com moldeiras individuais, confeccionadas, de modo a permitir uma espessura de material, de acordo com o alívio . As moldagens foram então realizadas e, deixadas polimerizarem em temperatura de $37^{\circ} \mathrm{C}$, com umidade relativa do ambiente de $100 \%$, os vazamentos foram executados com 5 minutos, 30 minutos, 1 hora, 2 horas, 8 horas e 24 horas. Os polissulfetos vazados com 24 horas, produziram troquéis consistentemente maiores; as siliconas, troquéis menores, em função do tempo. Os poliéteres produziram modelos menores, quando vazados antes de 8 horas e, maiores, quando vazados com 8 horas e 24 horas; o hidrocolóide reversível, permaneceu preciso nos primeiros 30 minutos, exibindo rápida diminuição do tamanho dos modelos, após esse período.

Os materiais de moldagem conhecidos como elastômeros, têm certas vantagens sobre os hidrocolóides reversíveis, razão por estar havendo um aumento no seu emprego, em certas situações clínicas. No geral, tratam-se de materiais que possuem melhor estabilidade dimensional e uma maior resistência ao rasgamento. McCABE; STORER ${ }^{103}$, em 1980, avaliaram as propriedades dos elastômeros dentro de 4 categorias: 1) características de polimerização, na qual os autores analisaram o tempo de trabalho $\left(23^{\circ} \mathrm{C}\right)$ e de polimerização $\left(32^{\circ} \mathrm{C}\right)$ através do uso de um "reômetro"; 2$)$ alterações dimensionais, pela analise do coeficiente de expansão térmica, contração de polimerização e perda de peso; 3) propriedades mecânicas, no qual fizeram teste de 
compressão e resistência ao rasgamento e 4) a habilidade do material em registrar retenções. Os materiais empregados para este estudo, foram, as siliconas de condensação, e as siliconas de adição, os poliéteres e os polissulfetos. Os resultados indicaram que: $1^{\circ}$ ) nenhum material é ideal para todas as aplicações clínicas; mas uma cuidadosa seleção pode resultar em moldagens satisfatórias, para algumas situações; $2^{\circ}$ ) as siliconas possuem boa elasticidade, mas sofrem alterações dimensionais significativas; $3^{\circ}$ ) as siliconas de adição, têm melhores estabilidade dimensional, mas são pobres em resistência ao rasgamento; $4^{\circ}$ ) os polissulfetos são resistentes, mas são visco-elásticos; $5^{\circ}$ ) os poliéteres possuem as várias propriedades balanceadas, mas são rígidos após a polimerização; $6^{\circ}$ ) as propriedades dos materiais das moldeiras e a espessura do material são parte importante na precisão da moldagem.

CIESCO et al. ${ }^{44}$, 1981, compararam a estabilidade dimensional e a precisão de alguns materiais de moldagens à base de borracha em diversos intervalos de tempo. Empregaram neste trabalho dois polissulfetos, duas siliconas (uma de polimerização por condensação e outra por adição), todos estes materiais possuíam consistência fluida e um poliéter que só é encontrado na consistência média. Duas técnicas de moldagem foram analisadas; uma que consistia no uso de uma moldeira individual e de um adesivo; e a segunda pelo emprego de moldeira de estoque. Os autores concluíram que, todos os materiais, cujos moldes foram vazados imediatamente e que foram confeccionados com o auxilio de uma moldeira em resina acrílica autopolimerizável e adesivo, apresentaram resultados superiores quando comparados àqueles com moldeiras de estoque, e que a silicona de adição apresentou melhores resultados do que o polissulfeto e silicona de polimerização por condensação.

BORGES FILHO ${ }^{29}$, em 1981, avaliou o desajuste cervical de coroas totais de ligas áureas em troquel de aço padrão, que foi previamente moldado com mercaptana e silicona pela técnica do casquete, proporcionando uma espessura de $0,5 \mathrm{~mm}$ para os referidos materiais. A alteração dimensional e a fidelidade na reprodução de detalhes 
dos elastômeros e do gesso tipo IV Vel-Mix foram também analisadas. Os moldes obtidos com os dois materiais de moldagem foram vazados com gesso tipo IV e os padrões de cera foram confeccionados a partir destes troquéis. Verificou um desajuste cervical médio de $35 \mu \mathrm{m}$, sem diferença estatisticamente significante entre os dois materiais, provavelmente devido à pequena espessura do material de moldagem, que fez com que as diferenças inerentes aos próprios materiais não se manifestassem, destacando que a técnica de moldagem seria mais importante que o material em si. A contração do material elastomérico em direção às paredes do casquete de resina, mais do que a expansão do gesso, estabelece troquéis maiores e coroas com maior facilidade de adaptação, menor desajuste cervical e menor retenção friccional. Concluiu que o desajuste cervical pode ser considerado clinicamente satisfatório, sendo o resultado mais de uma propriedade indesejada do elastômero (contração) do que propriamente de uma boa característica.

FARAH et al. ${ }^{64}$, em 1981, fizeram uma revisão da propriedade dos materiais de moldagem elastomérico, afirmando que; em anos recentes, materiais de moldagem têm sido desenvolvidos a partir dos polímeros líquidos; estes quando misturados com "catalisadores", são convertidos em elastômeros. Estes elastômeros deveriam ter precisão dimensional e estabilidade; eles ainda deveriam ter um tempo de polimerização razoavelmente curto e adequada vida útil, serem de fácil manipulação e bem aceitos pelos pacientes. Atualmente, três tipos de materiais elastoméricos são empregados na odontologia: os polissulfetos, os poliéteres e as siliconas. Os autores fazem recomendações sobre a seleção e manipulação dos materiais de moldagem elastoméricos. Tais recomendações compreendem: a mistura, de todos os materiais, vigorosamente até se obter uma massa homogênea e livre de bolhas; o uso de moldeiras individuais, que são melhores do que as de estoque; o respeito pelo tempo de polimerização, sugerido pelo fabricante; após a remoção da moldagem da cavidade oral, deixa-la descansar por 15 minutos, para permitir a recuperação elástica; o emprego 
de adesivos para polissulfetos não são indicados para poliéter e siliconas e, portanto não deveriam ser empregados.

BROWN $^{34}$, em 1981, avaliou os fatores que podem influenciar a precisão e a estabilidade dos materiais elastoméricos de moldagem, ressaltando que há dois aspectos ligados à estabilidade dimensional que estão relacionados ao operador; o material selecionado e a técnica empregada. Seu estudo concluiu que: $1^{\circ}$ ) os elastômeros são os materiais de moldagem mais estáveis e resistentes; $2^{\circ}$ ) todos apresentam contração, quando removidos da boca e colocados à temperatura ambiente; $3^{\circ}$ ) os polissulfetos apresentaram uma maior contração, devido a fatores controláveis e não controláveis, assim, restaurações simples, feitas em modelos de gesso, obtidos de moldagem com polissulfetos, fornecem espaço adequado para a camada de cimento; $4^{\circ}$ ) os poliéteres mostraram uma maior contração, devido às alterações térmicas, podendo esta ser compensada pelo armazenamento dos moldes em ambientes úmido; $5^{\circ}$ ) a siliconas do tipo I (polimerizadas por reação de condensação) apresentam uma pequena contração na estocagem, sendo esta propriedade vantajosa, quando se emprega material de consistência única ou quando da combinação "massa/fluido", contudo; a técnica da dupla moldagem com alívio apresenta contração excessiva, quando estocada por muito tempo; $6^{\circ}$ ) silicona tipo II (polimerizadas por reação de adição) são surpreendentemente estáveis na estocagem, permitindo o uso da técnicas de dupla mistura com alívio, na utilização de pasta de alta e baixa densidade.

LACY et al. ${ }^{87}, 1981$, estudando as diferenças ou similaridades, pela comparação de modelos, obtidos por 8 sucessivos vazamento (imediatamente após a polimerização, 30 minutos , 1 h, 2 hs, 4 hs, 24 hs, 48 hs e 96 hs depois do primeiro vazamento), estocando as moldagens à $21^{\circ} \mathrm{C}$. e umidade relativa de $50 \%$ - verificar a estabilidade dimensional de quatro classes de materiais de moldagem.. Concluíram que: $1^{\circ}$ ) embora a silicona polimerizada por condensação possa receber múltiplos vazamentos de uma mesma moldagem, elas produzem mudanças dimensionais por 
sucessivos vazamentos; $2^{\circ}$ ) o sistema massa/fluido exibiram diferenças entre as diferentes misturas, pois alguns produtos produziram uma série de modelos de diâmetro maior com 4 dias, enquanto outros produziram uma série de troquéis diminuídos, com sucessivos vazamentos; $3^{\circ}$ ) moldagem com silicona de baixa densidade e com moldeira de resina acrílica, utilizando adesivo, produziram modelos com maior diâmetro com os sucessivos vazamentos; $4^{\circ}$ ) o sistema massa/fluido, no geral, mostrou uma maior excentricidade dos modelos do que o sistema de baixa densidade com moldeiras individuais e adesivos, mas com algumas exceções significativas nas misturas; $5^{\circ}$ ) não existiu diferenças entre as técnica de moldagem única ou de dupla mistura, no sistema de silicona de polimerização por condensação; $6^{\circ}$ ) para uma máxima precisão, as siliconas polimerizadas por condensação deveriam ser vazadas o mais rápido possível.

Ainda em 1981, LACY et al. ${ }^{88}$, fez uma comparação quantitativa quanto à precisão e à estabilidade dimensional de produtos, representativos em cada classe de material de moldagem, para verificar o índice e a magnitude da mudança no tamanho dos modelos obtidos de vazamentos seqüenciais, sobre um período de 4 dias. Nos materiais utilizados incluíram um poliéter, 4 polissulfetos, e 4 siliconas (polimerizadas por reação de adição), e conluiaram que: $1^{\circ}$ ) os polivinilsiloxanos (siliconas de polimerizadas por reação de adição) são os elastômeros mais estáveis dos avaliados ; $2^{\circ}$ ) a precisão e a consistência são melhores mantidos pelo uso de moldeiras individuais e de adesivos para retenção das polivinilsiloxano; $3^{\circ}$ ) os polissulfetos, unidos às moldeiras individuais, apresentaram um aumento progressivo no diâmetro do modelo com o tempo. Os modelos produzidos pelos polissulfetos, com 4 dias, não são mais nem menos precisos do que os com silicona de condensação; $4^{\circ}$ ) o poliéter possui estabilidade intermediária entre o polissulfeto ou siliconas de condensação e o polivinilsiloxano, quando a técnica de moldagem envolve adesivo e moldeira individual; $5^{\circ}$ ) o sistema massa/fluido do polivinilsiloxano pode revelar uma perda de precisão, nos modelos obtidos por vazamentos múltiplos, após 2 e 4 dias; $6^{\circ}$ ) parece 
não haver diferenças pronunciadas entre as técnicas de simples e de dupla mistura, para os polissulfetos, quando se utiliza, para ambos, moldeira individual de acrílico.

Em 1981, AUGSBURGER et al. ${ }^{16}$ estudaram a precisão de vários materiais de moldagem (hidrocolóide reversível - Rubberloid; uma silicona de condensação Citricon, e uma silicona de adição - President) bem como a sua compatibilidade com o gesso (Vel-Mix), misturado com água de torneira ou com um endurecedor de gesso (Stalite). A precisão do modelo depende de vários fatores adicionais, tais como: o assentamento da moldeira nos tecidos, compatibilidade do material com o gesso para modelo, e a estabilidade dimensional do moldagem. Concluíram que: $1^{\mathrm{o}}$ ) President foi ligeiramente mais preciso do que Rubberloid. A diferença entre Citricon e President e entre Citricon e Rubberloid não foram estatisticamente significantes; $2^{\circ}$ ) a moldeira com adesivo para hidrocolóide melhora a precisão da moldagem, $3^{\circ}$ ) a discrepância dos modelos, produzidos a partir de todos os materiais testados, foi aumentado quando, dependendo do uso do endurecedor de gesso, na mistura para se confeccionar os modelos.

ARIKAWA et al. ${ }^{12}, 1982$, testando um instrumento que determinasse o tempo de trabalho e polimerização de materiais de moldagem, analisaram 4 polissulfetos, 8 siliconas e 1 poliéter. Os materiais foram dosados e manipulados de acordo com as recomendações dos fabricantes à temperatura ambiente de $23 \pm 0,5^{\circ} \mathrm{C} \mathrm{e}$ a polimerização à $23 \pm 0,5^{\circ} \mathrm{C}$ ou $32 \pm 0,5^{\circ} \mathrm{C}$. O poliéter e as siliconas obtiveram valores máximos de recuperação elástica em 5-6 minutos, os polissulfetos, sua recuperação elástica máxima ocorreu aos 13 minutos após a mistura. Frente a esses resultados, segundo os autores, as siliconas e o poliéter podem ser usados em situações em situações que requerem maior exigências, quando comparados com os polissulfetos.

A alteração dimensional, sobre quatro condições de seis materiais de moldagem, foi estudada em 1982, por JÖRGENSEN ${ }^{83}$. Os materiais usados foram: 
Exaflex, Permagum, President, Reflect, Reprosil e Xantogum. Os registros do coeficiente de expansão e contração térmica foi inicialmente feito com o uso de dilatometro de mercúrio. Porém, devido à geração de gazes, pelas espécimes testadas, este método teve de ser abandonado, substituindo-o por um Mikrokator, com unidade de carga de 0,5 g e uma precisão de leitura de 0,1 $\mu \mathrm{m}$ foi usada, para registrar a expansão e contração térmica linear dos materiais. Os produtos foram manipulados de acordo com as normas dos fabricantes; as espécimes foram produzidas em um molde cilíndrico, com $5 \mathrm{~mm}$ de diâmetro e $10 \mathrm{~mm}$ de altura, com superfícies planas e paralelas. Os corpos de prova foram deixados descansar por 15 minutos, para a polimerização, na temperatura ambiente e, após, estocados por um mínimo de 12 horas, a $37^{\circ} \mathrm{C}$, antes das mensurações. Moldagem de três troquéis de aço inoxidável truncados, foram realizadas, empregando-se moldeiras em aço, retangulares e perfuradas. $\mathrm{O}$ dispositivo de moldagem era pré-aquecido em uma panela com água, à $37^{\circ} \mathrm{C}$ : temperatura esta mantida por um termostato. As moldagens foram feitas nas temperaturas de $22^{\circ} \mathrm{C} ; 37^{\circ} \mathrm{C} ; 37^{\circ} \mathrm{C}$ com resfriamento para $22^{\circ} \mathrm{C}$ e desta com reaquecimento para $37^{\circ} \mathrm{C}$. Os moldes foram vazados com gesso Vel-Mix adicionandose bórax, para reduzir a expansão de presa. $\mathrm{O}$ autor concluiu que, pelo emprego de gesso, para troquéis com efeito de expansão de presa mínimo, e pelo uso da técnica do reaquecimento, na moldagem de siliconas de adição estáveis estudadas e que é possível se conseguir modelos com desviação mínima do tamanho do dente preparado.

MARCINAK; DRAUGHN ${ }^{99}$, em 1982, investigaram a estabilidade dimensional de várias siliconas polimerizadas por reação de adição. Utilizaram um modelo mestre, com dois incisivos centrais superiores, os quais tinham sido montados em um bloco de resina acrílica e armazenados em água, no interior de uma estufa, a $37^{\circ}$ C, com umidade relativa de 100\%. Moldeiras individuais foram confeccionadas, permitindo uma espessura do material de moldagem de $3 \mathrm{~mm}$ e foi aplicado adesivo às moldeiras, de acordo com as orientações dos fabricantes. As moldagens foram feitas e os, modelos confeccionados com gesso (Vel-Mix), enquanto os vazamentos foram 
realizados após 10 minutos, 30 minutos, 2, 4, 8, 48, 98 e 168 horas. Tais modelos foram medidos e comparados ao modelo mestre, para determinar as mudanças lineares. Os autores concluíram que: $1^{\circ}$ ) o President produziu modelos maiores que o modelo mestre; contudo apresentou um desvio, ainda que de $0,1 \%$, em relação ao modelo mestre; $2^{\circ}$ ) o Permagum (massa/leve) foi o mais instável, produzindo modelos maiores que o padrão, isto é acima de $0,3 \% ; 3^{\circ}$ ) Três materiais produziram, ao acaso modelos maiores ou menores, diferindo do modelo mestre por somente $0,08 \%$, para os menores; e de $0,07 \%$, para os maiores; $4^{\circ}$ ) Nenhum modelo, consistente de aumento ou de diminuição no tamanho, ocorreu com o tempo. Modelos produzidos com 168 horas foram tão precisos quanto aqueles produzidos em 10 minutos. Salientaram que, embora não haja subprodutos decorrente da polimerização destes materiais, a alteração dimensional depende da contração térmica que ocorre com o material, quando este sai da temperatura bucal $\left(37^{\circ} \mathrm{C}\right)$ para a temperatura ambiente.

Ao realizarem um estudo das alterações dimensionais nas áreas oclusais de dentes preparados, $\mathrm{ABBADE}^{1}$ et al., em 1983, usando duas técnicas de moldagem, sendo uma com alívio e a outra pela dupla mistura, empregando para tanto uma silicona de condensação (optosil/xantopren) concluíram que quando se utiliza o alívio a moldagem é mais precisa.

Em uma avaliação dos materiais de moldagem elastoméricos, GULKER ${ }^{72}$, 1983, apresentou uma série de requisitos para obtenção de uma boa moldagem, que incluía: a saúde dos tecidos e uma completa visão do término cervical; as moldeiras estáveis, firmes e apropriadas; a precisão dos materiais de moldagem e os materiais dos troquéis duráveis e precisos. Sugeriu o uso de afastamento gengival, com fios retratores sem epinefrina e o emprego de moldeiras individuais, com alívios de 2 a $4 \mathrm{~mm}$, para o material de moldagem. Destacou, como elastômeros de sua preferência, as siliconas de adição (polivinilsiloxanos) e os poliéteres, por apresentaram uma boa estabilidade dimensional. Alertou a respeito do uso das siliconas de adição, com a eliminação de 
gazes de hidrogênio, pois estes materiais não devem ser vazados imediatamente, e sim após ter decorrido a primeira hora. Deste modo poder-se-ia evitar o aparecimento de bolhas, na superfície do modelo de gesso.

Os valores de contração de polimerização dos materiais elastoméricos de moldagem, conforme o estabelecido pelos fabricantes, são normalmente obtidos pelo método descrito como o especificado pela norma de $\mathrm{N}^{\mathrm{o}} 19$ da A.D.A., ou por métodos de mensuração não específicos e não padronizados. Fatores como: resistência, fricção entre os materiais testados e a placa de suporte, o tempo completo de polimerização após a mistura, podem ter influências significativas sobre o resultado final. Os dados publicados freqüentemente não computam estes procedimentos. OHSAWA; JÖRGENSEN $^{113}$, em 1983, apresentaram um estudo para determinar a contração de polimerização, de seis marcas comerciais de siliconas de adição: Exaflex, Permagum, President, Reflect, Reprosil e Xantogum . A contração linear livre, foi determinada pelo método de banho em mercúrio e modificada por JÖRGENSEN, em um período de 24 hs, na temperatura ambiente de $22 \pm 2^{\circ} \mathrm{C}$. Os materiais foram dosados e manipulados, de acordo com as orientações dos fabricantes, sendo que o tempo de manipulação foi de 30 segundos. De acordo com os resultados obtidos, os materiais estudados podem ser classificados em dois grupos; $1^{\circ}$ ) aqueles que apresentam contração máxima de $0,08 \%$, 15 minutos, após a mistura e de $0,03 \%$ no período subsequente até 24 horas (Permagum, President, Reflect e Reprosil); $2^{\circ}$ ) materiais com contração acima de 0,08\%, 15 minutos, após a mistura e acima de 0,03\%, no período posterior (Exaflex e Xantogum). O efeito da contração de polimerização, em condições clínicas, não apresentam possibilidades de serem verificados. Durante a polimerização, na boca, a pressão que ocorre no material pela moldeira e pelos tecidos, faz com que os excessos escoam para as margens das moldeiras, havendo, portanto, uma redução na contração efetiva do material na boca. 
$\mathrm{O}$ rasgamento nas margens do preparo dos materiais de moldagem - onde o material freqüentemente tem menor volume ou encontra uma retenção mecânica consiste em um problema para o dentista. Como propriedade física, a força de rasgamento dos materiais de moldagem merece consideração. Os polivinilsiloxanos recentemente introduzidos, apresentaram uma melhora geral nas propriedades físicas sobre as siliconas de condensação. As siliconas de adição (polivinilsiloxanos), demonstram melhores estabilidades dimensionais e deformações permanentes que superam àquelas apresentadas pelas siliconas de condensação, possuindo também uma menor porcentagem no valor de escoamento do que alguns materiais de moldagem à base de borracha. Esta nova geração de siliconas perderam a flexibilidade, e são por isso, mais difíceis de serem removidas da boca. Os Poliéteres são sempre mais rígidos, apresentando um maior grau de dificuldade. A perda da flexibilidade pode contribuir para o rasgamento do material, quando da sua remoção de áreas retentivas. SNEED et al. $^{138}$, 1983, examinaram a força ao rasgamento apresentada por certos polissulfetos, por siliconas convencionais, por um poliéter e, em particular, pelos recentemente introduzidos polivinilsiloxanos. Foram empregados dez materiais de moldagem: Permlastic R, Permlastic L, Healthco R, Heltthco L, Reflex, Reprosil, Zylox, Impregum, Impregum F com modificador de corpo, e Optosil/Xantopren). Os produtos foram manipulados, segundo as orientações dos fabricantes, na temperatura ambiente de $25^{\circ} \mathrm{C}$. Uma lâmina de alumínio serviu como molde. Um spray de silicona foi usado na lâmina de alumínio como um agente isolante. Imediatamente, após a amostra estar posicionada no molde, o conjunto era colocado em uma incubadora a $37^{\circ} \mathrm{C}$, para simular a temperatura da boca. A seguir, os espécimes eram deixados para polimerizarem pelo tempo recomendado pelos fabricantes, separados e a seguir levados a uma máquina hidráulica de teste. Dos resultados deste estudo, concluíram que; os polissulfetos foram mais resistentes, seguido do Reflect, abaixo dos polissulfetos, mas acima dos outros materiais testados. Afirmaram ainda, que quando o dentista, necessitar de um material resistente, para um procedimento clínico específico onde, a espessura 
do material, será fina e/ou em uma área de stress, deveria empregar ou o polissulfeto ou um mistura simples de polivinilsiloxano.

Observações empíricas tem indicado que modelos resultantes de siliconas polimerizadas por adição (polivinilsiloxanos) apresentam freqüentemente porosidades superficiais. Para eliminar estes problemas, os clínicos, adiam o vazamento do molde por várias horas. Existe ainda uma carência de informações sobre exatamente a que horas deve-se vazar o molde. Devido estas evidências, ASGHARNIA; et al. ${ }^{14}$, em 1983, estudaram as siliconas Reprosil e Reflect, obtendo moldes de um modelo padrão. Os moldes foram vazados nos seguintes intervalos de tempo; 0, 15 e 30 minutos, 1, 2, 4, 6, 8, 12 e 24 horas, após a sua confecção sendo obtidos 5 amostras de cada material. Os modelos foram observados em microscopia ótica, com um aumento de 10x. O número de poros e as diferentes localizações nas cúspides do $2^{\underline{0}}$ molar, foram contados e registrados em cada um dos 5 modelos. Concluíram que; $1^{\circ}$ ) os dois materiais mostraram a mesma tendência em exibir poros; $2^{\circ}$ ) a menor e a maior quantidade de poros foram encontradas após 15 minutos e 1 hora para o Reprosil e no vazamento imediato e 30 minutos para o Reflect respectivamente; $3^{\circ}$ ) o número de poros decresceu gradualmente após 1 hora e quase nenhum foi identificado após as 24 horas. Desta observação foi ainda possível identificar que um mínimo de porosidade foi obtido quando o vazamento se deu nos primeiros 15 minutos ou 24 horas após a moldagem. Um período de espera longo, para o vazamento do molde, pode entretanto causar alterações irreversíveis no molde.

FINGER; OHSAWA ${ }^{66}, 1983$, analisaram as propriedades reológicas de três marcas de siliconas de polimerização por reação de adição: Exaflex, President e Xantogum, durante a polimerização e, avaliaram o relacionamento das propriedade reológicas encontradas, com a efetiva contração de polimerização destes materiais. Destes estudo concluíram que; $1^{\circ}$ ) a contração de polimerização livre, das siliconas estudadas e a precisão dos modelos gesso, produzidos por estas siliconas, 
imediatamente após 24 horas, não apresentaram correlação; $2^{\circ}$ ) o desvio no diâmetro da base dos modelos de gesso foi, no máximo, de $10 \mu \mathrm{m}$, quando se realizou vazamento imediato ou 10 minutos após a remoção da moldagem; entretanto, quando a moldagem foi armazenada por 24 horas, o desvio foi de $27 \mu \mathrm{m}$, para o Exaflex; de $7 \mu \mathrm{m}$ para o President e de $11 \mu \mathrm{m}$ para o Xantogum; $3^{\circ}$ ) o material President foi o mais preciso, registrando pequena contração, durante a polimerização e armazenamento.

A estabilidade dimensional é uma propriedade física desejável nos materiais de moldagem usados na odontologia, os dentistas, são freqüentemente impedidos de vazarem os moldes imediatamente após o ato de moldagem, necessitando de um período de tempo para sua execução, sem que haja alteração em sua fidelidade. CLANCY et al. ${ }^{45}$, em 1983, estudaram e compararam a estabilidade dimensional de três materiais de moldagem; um poliéter (Polygel), uma silicona de polimerização por adição (Reprosil/regular) e, uma por condensação(Denture elasticom/regular), com o vazamento sendo executado em oito períodos de tempo: imediatamente, após 4, 24 e 48 horas e 1, 2, 3 e 4 semanas. Concluíram que o Reprosil e o Polygel possuem um comportamento similar com o passar do tempo, existindo uma pequena alteração dimensional após 4 semanas; o Denture elasticom é significativamente menos estável que os outros demais materiais, quando o tempo para o vazamento é maior, podendo ocorrer distorções significantes em 4 horas; todos os três materiais mostraram mais precisão quando vazados imediatamente após a obtenção do molde; o molde obtido com o Reprosil é o que melhor reproduz detalhes superficiais e o Denture elasticom perde em muito na reprodução de detalhes, quando o vazamento ocorre após 24 horas. Quando o este não pode ser executado imediatamente após a obtenção do molde, o material de eleição deve ser o Reprosil.

CHEVITARESE; SCELZA; AMARANTE ${ }^{40}$, em 1983, destacaram alguns aspectos relacionados às técnicas de moldagem, visando a obtenção de resultados satisfatórios. A técnica complementar ou de reembasamento sem alívio, quando se 
utiliza silicona, apresenta um grande inconveniente por não prover um espaço para o material de moldagem propriamente dito, isto é, a silicona leve. Este aspecto cria dificuldade crescente ao fluxo desta, a partir da face oclusal, onde a silicona é mais abundante, dificuldade esta que é aumentada,também, pela crescente viscosidade desse material em função de sua polimerização. Em consequiência, a força com que se comprime a moldeira pode desenvolver deformação, principalmente ao nível da face oclusal do primeiro molde, que será maior ou menor, dependendo da força externa aplicada. Após a remoção da moldeira, a silicona densa tende a voltar à posição original, levando consigo a silicona leve, promovendo deformação. Salientam que, evidentemente, um modelo obtido desta forma poderá não reproduzir a contento a superfície moldada, sob o ponto de vista clínico. Quando o dente apresenta estrangulamento ou retenção abaixo da terminação cervical, ocorre uma acentuada deformação da projeção da silicona nesta região, por compressão, principalmente, pelo impedimento da moldeira atingir a posição inicial, sendo que o material leve estará ausente, junto à região cervical e acumulado na região oclusal. Removido o molde, ocorrerá o relaxamento das tensões introduzidas durante a segunda moldagem, com consequiente deformação. Para contornar esse problema os autores descrevem que o alívio da silicona densa, com remoção de cerca de 1 a 2 milímetros do material, permite o escoamento do material leve e, em conseqüência, a obtenção de um molde praticamente sem tensões.

Segundo KEMPLER et al. ${ }^{85}$, 1983, os materiais de moldagem, à base de silicona, têm sido empregada extensivamente, nas duas últimas décadas, pelos dentistas. Com a introdução no mercado das siliconas de polimerização por adição, estas se tornaram de grande aceitação para o clínico. Fatores relacionados com a manipução, tais como: facilidade de mistura, tempo de trabalho e de polimerização e o modelo resultante são de importância primordial. Nesta pesquisa, três siliconas de condensação e uma de adição foram comparadas por cinco professores clínicos, em suas propriedades de manipulação e manuseamento e, a compatibilidade dos materiais 
de moldagem com os gessos para troquel, também foram testados. Executaram moldagens de um troquel de metal, com os materiais sendo dosados e manipulados de acordo com as orientações dos fabricantes. Empregaram moldeiras de estoque metálicas, perfuradas, juntamente com o adesivo indicado pelos fabricantes. Todas as moldagens foram realizadas pela técnica de dupla moldagem, sendo vazadas, imediatamente, três minutos e duas horas, após a separação do molde do troquel. As leituras dos modelos foram feitas em micrometros, em um microscópio. Concluíram que o sistema "pasta-pasta" é o preferido, ressaltando que a coloração diferente, dos materiais, permite uma melhor visualização, depois do reembasamento. Relataram que, para as siliconas de condensação, os moldes deveriam ser vazados nos primeiros minutos e que as siliconas de adição podem ser armazenadas, para posterior vazamento, pois apresentam maior estabilidade dimensional.

Materiais de moldagem à base de borracha são altamente precisos e largamente empregados, na confecção de modelos para próteses parciais fixas. Estes materiais são mais estáveis, quando sua espessura for de 2 a 4 mm, conseguida com o uso de moldeiras individuais de resina acrílica. Porém estes materiais podem distorcerse, durante a polimerização, e mais, a dependência do aumento da temperatura e de outras propriedades elásticas, comparadas à moldeira de metal, pode pôr em risco as boas qualidades dos materiais de moldagem. Finalmente, a construção de moldeiras individuais consomem custo e tempo, sendo uma alternativa, o uso de moldeiras de estoque. Devido às poucas informações existentes, no que diz respeito a estes métodos, VALDERHAUG; FLÖYSTRAND ${ }^{149}$, em 1984, avaliaram e compararam a estabilidade dimensional das moldagens realizadas com moldeiras de estoque metálicas e as com moldeiras individuais, de resina acrílica. Dois modelos metálicos superiores foram produzidos: os dentes em aço inoxidável, tinham uma expulsividade de $10^{\circ}$, para a oclusal, sendo o modelo "A", com retenções similares à dentição normal e o "B", cujos dentes não possuíam retenções. Os modelos foram fixados em aparelhos que posicionavam as moldeiras em uma única posição. Moldagens foram feitas, usando 
moldeiras de estoque (Martin $\mathrm{n}^{\mathrm{\rho}}$ 3) e individuais de resina acrílica ( permitindo uma espessura de 2 a $4 \mathrm{~mm}$ de material de moldagem ), com Impregum $\mathrm{F}$ e Xantopren. Todos os materiais foram manipulados de acordo com as recomendações dos fabricantes. A parte experimental consistia de: 1) dois tipos de moldeiras; 2) dois tipos de materiais de moldagem; 3) duas situações clínicas. As moldagens foram executadas e medidas imediatamente, ou estocadas por 1 e 24 horas, em temperaturas de $21^{\circ} \mathrm{C}$ e $50 \%$ de umidade relativa. Pelos resultados obtidos, concluíram que; uma das objeções ao método usado foi de que todas as medidas se restringiram ao plano horizontal e nenhuma informação foi obtida, no que diz respeito à estabilidade tridimensional nas moldagens testadas. A estabilidade dimensional, neste estudo, é resultado não somente do material de moldagem em si, mas também devido aos agentes adesivos às $\mathrm{e}$ moldeiras não perfuradas, com limitadas propriedades elásticas. A estabilidade dimensional linear das moldagens, com moldeiras de estoque, não foram inferiores às moldagens com moldeiras individuais, em acrílico.

BOMBERG; HATCH ${ }^{25}$, em 1984, avaliaram a aceitabilidade de moldes, levementes defeituosos, obtidos através de uma técnica corretiva. Para tanto empregaram 2 poliéteres (Impregum F e Poligel) e 3 siliconas polimerizadas por adição (Reprosil, President e Permagum). As discrepâncias marginais existentes, pela adaptação das fundições sobre os modelos obtidos do primeiro molde, foram comparadas com as existentes sobre os obtidos, destes mesmos moldes, após a moldagem corretiva. Com o intuito de evitar a pressão, exercida pela correção do molde defeituoso, os autores, fizeram perfurações, para facilitar o escoamento do excesso de material. Os resultados obtidos contra-indicaram o uso de material de moldagem corretivo e a necessidade de se refazer a moldagem. Todos os materiais testados levaram a um desajuste três vezses maiores para o modelo corrigido.

Em recentes publicações, pesquisas revelaram que mais de um terço de todos os materiais elastoméricos de moldagem, são vazados 1 hora ou mais após sua 
confecção. Com a introdução dos polivinilsiloxanos, que possuem reação de polimerização por meio de adição, a Odontologia passou a ter um material com melhor estabilidade dimensional. Esta é atribuída à ausência de produtos com reação voláteis como a água e o álcool, que são normalmente produzidos pelos polissulfetos e siliconas de condensação, durante a polimerização. E mais, o odor, gosto e a cor são mais aceitáveis pelos pacientes. WILLIANS et al. ${ }^{152}$, 1984, compararam a estabilidade dimensional de vários polivinilsiloxanos com polissulfetos, siliconas de condensação e poliéteres, usando meios similares àqueles empregados nas situações clínicas. Onze materiais de moldagem comerciais foram avaliados, sendo três polissulfetos, uma silicona de condensação, um poliéter e seis siliconas de polimerização por adição. A precisão de cada material foi avaliada pela moldagem de um troquel-padrão de ouro polido, que representava um preparo para coroa total e no qual se adaptava uma coping em ouro, que possuía 10 marcas de referência na sua margem. Moldeiras individuais de acrílico foram confeccionadas 24 horas antes das moldagens, e forneciam um espessura uniforme de material de $2 \mathrm{~mm}$ de espessura e, os adesivos, dos respectivos materiais foram aplicados. Foram feitas moldagens do troquel-padrão, os quais tinham sido préaquecidos a $37^{\circ} \mathrm{C}$ e os materiais foram dosados e misturados de acordo, com as normas dos fabricantes. Após a espatulação, este foi colocado sobre o troquel-padrão , a moldeira foi carregada e posicionada sobre o mesmo, em uma posição previamente estabelecida. O conjunto era então colocado em uma bacia com água a $37^{\circ} \mathrm{C}$, e aguardava-se a polimerização,. Após decorridos dez minutos, da mistura, o conjunto era separado e os moldes ou eram vazados imediatamente com gesso Vel-Mix ou estocados por 1, 4 ou 24 horas, em temperatura e umidade ambiente e, a seguir vazados. Após o vazamento, eram deixados para descansar por 1 hora, antes de serem separados dos moldes. O coping era assentado sobre o troquel de gesso e a abertura marginal existente, entre estes, nas marca de referência, eram medidas em micrometros, com um microscópio. Dos resultados obtidos concluiram que: $1^{\circ}$ ) a maior precisão foi conseguida com a moldagem sendo vazada imediatamente; $2^{\circ}$ ) todas as siliconas de adição exibiram excelente estabilidade dimensional, para todos os tempos de 
estocagem; $3^{\circ}$ ) a silicona de condensação teve boa precisão, quando vazada imediatamente, pois vazamento posteriores resultaram em rápida perda de precisão; $4^{\circ}$ ) os polissulfetos apresentam boa estabilidade dimensional, quando vazados imediatamente; enquanto o poliéter expande durante a estocagem; $5^{\circ}$ ) a alteração dimensional da moldagem, durante a estocagem, é característica do material, visto que a redução no seu volume levaria a uma desejada quantidade de alteração dimensional. Para se conseguir esta condição, moldeiras individuais deveriam ser construídas para permitir um mínimo de material de moldagem.

ARAÚJO; JÖRGENSEN ${ }^{6}$, em 1985, estudaram o efeito do volume e da redução da espessura dos materiais de moldagem, em relação à sua precisão. Utilizaram dois materiais, sendo uma mercaptana (Permlastic R) e uma silicona de adição (President R). Um troquel truncado de aço crômio foi utilizado como padrão. Este troquel possuía anéis de 3,2 e $1 \mathrm{~mm}$, que calibrava a retenção na região cervical em 1,5, 1 e $0,5 \mathrm{~mm}$, respectivamente. Os materiais foram manipulados à temperatura de 22 $\pm 2^{\circ} \mathrm{C}$, polimerizados em água a $37^{\circ} \mathrm{C}$, por 15 minutos. Após separarem o molde do troquel metálico, este molde era deixado por 10 minutos à temperatura ambiente e, então, vazado com gesso Tipo IV (Duroc). Após 2 horas na temperatura ambiente, o modelo era separado do molde e levado ao microscópio, para o registro das medidas e comparação destas com as do troquel-padrão. Concluíram que um aumento da quantidade do material de moldagem resulta em uma maior imprecisão do que o aumento na magnitude das retenções do preparo.

$\mathrm{CRAIG}^{51}$, 1985. avaliou um sistema de auto mistura para silicona de adição, sendo as duas pastas fornecidas em dois cilindros e misturadas pelo empurrão deles, através de um bico estático que acompanha o sistema para determinar as propriedades e fidelidade do material de moldagem. Conclui que este sistema fornece uma mistura uniforme da base como o catalisador, eliminando o treinamento da 
auxiliar; é econômico, pois somente 1/3 do material utilizado na manipulação manual é despendido e, mantém o padrão de qualidade das siliconas de adição.

CONTIN; UETI $^{49}$, em 1985, analisaram a alteração dimensional de troquéis em gesso Vel-Mix em relação a um troquel metálico padrão que simulava um preparo para coroa total. Os troquéis foram obtidos por duas técnicas de moldagem: casquete de resina acrílica + mercaptana (Permlastic Regular) e moldeira individual de resina acrílica + mercaptana. Observaram que todos os troquéis apresentaram-se ligeiramente maiores, com expansão de 1,21\% para a técnica do casquete e de 1,37\% para a moldeira individual de acrílico. Justificam tal fato pela contração dos materiais de moldagem e expansão de presa do gesso Vel-Mix. Os troquéis também se apresentavam expandidos em largura e levemente contraídos em altura gengivo-oclusal. Os autores destacam que, do ponto de vista clínico, se por um lado os troquéis expandidos seriam vantajosos por ajudar a compensar a contração de fundição da liga metálica, por outro poderiam dificultar o ajuste da borda da restauração no próprio modelo ou no próprio preparo.

Existem seis tipos de materiais de moldagem na odontologia: hidrocolóide reversível, hidrocolóide irreversível, siliconas de polimerização por condensação, siliconas de polimerização por adição, poliéteres e polissulfetos. LINKE et al. ${ }^{94}, 1985$, fizeram uma análise comparativa dos materiais de moldagem e de suas combinações para determinar; 1) a magnitude e a direção da distorção, dentro do arco dental, 2) a distorção horizontal, entre os retentores, e 3) a distorção horizontal e vertical, nos modelos individuais. Um sistema de modelo em alumínio polido, modificado por Kaiser; Nicholls, para diminuir a espessura do material de moldagem, foi empregado. Neste sistema existiam dois retentores de cada lado do arco: na região de primeiros molares e pré-molares e um retentor no centro do segmento anterior, sendo a distância entre cada par de retentores idênticas. O modelo padrão foi estocado em um umidificador, com temperatura constante de $36,5^{\circ} \mathrm{C}$ e umidade relativa do ar de $100 \%$, antes da moldagem ser executada. Seis materiais de moldagens de diferentes tipos 
foram testados: polivinilsiloxano (massa/fluido - Reprosil), silicona regular + hidrocolóide irreversível (Ultrafine), silicona regular/fluida + hidrocolóide irreversível, hidrocolóide irreversível (Jeltrate), combinação modificada de hidrocolóide reversível com irreversível (Colloid 80), e hidrocolóide reversível (fluido/pesado - Rubberloid). Foram feitas seis moldagens por material do modelo padrão. Os materiais foram manipulados de acordo com as orientações dos fabricantes, sendo as siliconas misturadas por 30 segundos, o hidrocolóide irreversível foi misturado à vácuo, por 15 segundos e o hidrocolóide reversível foi deixado em uma unidade condicionadora por 10 minutos e, a seguir, deixados em temperatura de $160^{\circ} \mathrm{F}$, por um mínimo de 1 hora. Todos os moldes foram vazados imediatamente com gesso melhorado, exceção do polivinilsiloxano que foi deixado para descansar por 30 minutos, antes do vazamento. Os modelos obtidos foram retirados dos moldes e estocados por 24 horas, antes de se iniciar a medição, executadas em um microscópio de precisão de 10 aumentos, observando-se os eixos $\mathrm{X}, \mathrm{Y}$ e $\mathrm{Z}$. Os autores concluíram que: $1^{0}$ ) todos os modelos tiveram um perímetro de arco maior do que o padrão; $2^{\circ}$ ) hidrocolóide reversível produziu menor distorção entre os retentores do que os outros materiais; $3^{\circ}$ ) silicona mais o hidrocolóide irreversível produziram menor distorção entre os retentores do que o hidrocolóide irreversível, houve diferenças estatisticamente significantes, quanto à quantidade dos materiais de moldagem; porém, a combinação de hidrocolóide irreversível, com silicona e de hidrocolóide reversível, modificado com hidrocolóide irreversível são clinicamente aceitáveis, dentro dos conceitos atuais.

Em 1985, ARAÚJO et al. ${ }^{10}$, testaram as propriedades visco-elásticas dos materiais de moldagem à base de borracha e registraram as relações entre a deformação induzida e permanente dos materiais elastoméricos, durante e após o reaquecimento. Através do mesmo equipamento, foi possível medir a recuperação elástica dos materiais após a deformação. O equipamento usado foi um reômetro, baseado no princípio coneplaca, que permitiu registro eletrônico do deslizamento gradativo básico, durante a presa dos materiais. O tempo de recuperação elástica sugere que o vazamento do molde 
pode ser feito de 7-10 minutos, após a moldagem ser obtida. Concluíram, ainda que, $60 \%$ das deformações foram induzidas ao material, pela remoção deste da estrutura, com retenções de $1 \mathrm{~mm}$ na altura e profundidade.

ARAÚJO; JÖRGENSEN ${ }^{7}$, em 1986, investigaram qual o efeito do reaquecimento das siliconas de adição sobre a dimensão dos troquéis de gesso Tipo IV (Duroc), por comparação com o troquel-padrão. Os moldes foram obtidos com moldeiras que permitiam uma espessura de material de moldagem de 1 e $4 \mathrm{~mm}$ e, na oclusal do troquel à base da moldeira, de $2 \mathrm{~mm}$, e imersos (molde + modelo padrão) em água a $37^{\circ} \mathrm{C}$, até a polimerização final. Os modelos de gesso foram obtidos de duas maneiras: a) resfriamento a $22^{\circ} \mathrm{C}$ por 10 minutos; e b) resfriamento do molde a $22^{\circ} \mathrm{C}$, e a seguir, reaquecimento a $37^{\circ} \mathrm{C}$, por 30 minutos. Concluíram que o reaquecimento dos moldes aumentou a precisão, e também que o aumento da espessura do material de moldagem, acarreta uma maior distorção. Salientaram, ainda que, se deve empregar um gesso que apresente apropriada expansão de presa, propiciando desta forma um mínimo desvio das dimensões dos dentes preparados.

A estabilidade das restaurações fundidas são grandemente afetadas pela precisão dos modelos de trabalho e, por esta razão, diversos pesquisas são conduzidas, sobre este assunto. HABU; KOBAYASHI ${ }^{74}$, 1986, estudaram diferentes tipos de materiais de moldagem, alginato (Algiace Powder), polissulfeto (Surflex) e silicona de adição (Exaflex), obtidos de três tipos de troquéis metálicos padronizados e vazados com gesso tipo IV (New Plastone). Os materiais foram empregados de acordo com as normas dos fabricantes. Os modelo padronizados tinham a forma (1) paralela, (2) expulsiva, a $10^{\circ}$ e (3) retentivo, a $10^{\circ}$, uma moldeira metálica de $5 \mathrm{~mm}$ de espessura foi usada em todas as moldagens. Os vazamento ocorriam 3 minutos após a remoção do molde do modelo padrão, o tempo de polimerização dos materiais foram, para o alginato, de 6 minuto; para o polissulfeto, de 12 minutos e de 8 minutos, para as silicona. Uma hora após o vazamento, foram separados e 24 horas depois, as leituras 
foram feitas. Todo o experimento foi realizado em temperatura controlada de $23 \pm 1^{\circ} \mathrm{C}$ e com a umidade relativa do ar de $50 \pm 10 \%$. As medidas foram realizadas com um digitador tridimensional, avaliando-se a precisão dimensional da altura e do diâmetro. Os resultados mostraram que; $1^{\circ}$ ) os modelos obtidos do alginato, no caso do troquel de paredes paralelas, tiveram a altura e o diâmetro aumentados, uniformemente e, no de paredes expulsivas, a altura era correta; porém o diâmetro se mostrava aumentado, especialmente na porção superior. No caso do troquel com retenção, a altura foi uniformemente maior e o diâmetro estava aumentado em todas as porções; $2^{\circ}$ ) o troquéis obtidos do polissulfeto, no modelo com retenção, apresentava altura particularmente maior, mas o diâmetro foi correto; no expulsivo, a altura foi despresivelmente maior e o diâmetro foi gradualmente maior na porção superior, correto na central, mas levemente menor na porção inferior; no com retenção, a altura foi igualmente maior ao do alginato e o diâmetro também foi maior; $3^{\circ}$ ) nos troquéis obtidos com silicona de adição, a altura foi levemente maior e o diâmetro foi correto na porção superior, para o paralelo, mas levemente menor na inferior; no expulsivo, ambos, altura e diâmetro foram precisos, mas o diâmetro foi levemente menor na porção inferior; no retentivo, ambos, altura e diâmetro foram uniformemente maiores, apesar de desprezível; porém, no caso do troquel de silicona, a recuperação elástica foi melhor do que daqueles feitos com os outros dois materiais.

Várias técnicas têm sido desenvolvidas para melhorar a precisão das moldagens, usadas na confecção de coras e próteses parciais fixas. A técnica massa/fluido é recomendada, devido à contração de polimerização das siliconas de condensação. Entre os desenvolvimentos que melhoram a precisão das moldagens estão o emprego de moldeiras individuais e de materiais com dupla viscosidade, técnica de moldagem da dupla mistura. A técnica de moldagem massa/fluido tem sido estendida para as siliconas de adição, embora estas sejam dimensionalmente estáveis. JOHNSON; $\mathrm{CRAIG}^{82}$, em 1986, pesquisaram as diferenças na precisão, que existem como resultado destes fatores, e também para indicar quais combinações de resultados são mais 
precisos. O segundo objetivo foi comparar a precisão das siliconas de adição com as siliconas de condensação. O estudo visou auxiliar o dentista, oferecendo-lhes subsídios para a seleção de um produto; a viscosidade, e o tipo de moldeira, quando do emprego de uma siliconas de adição. A precisão dos materiais de moldagem foi determinada pela mensuração em sete locais diferentes dos modelos de gesso, obtidos da moldagem de um troquel-padrão metálico. Foram empregados quatro marcas comerciais de silicona de adição: President, Mirror 3, Exaflex e Cinch e uma silicona de condensação o Coltex/Coltoflax. Usaram-se três técnicas de moldagem: massa/fluido, dupla mistura e simples mistura, para cada material. Três moldeiras de estoque e uma moldeira individual, todas do mesmo tamanho, foram usadas, sendo todas elas perfuradas para dar retenção. Os materiais foram manipulados de acordo com as orientações dos fabricantes. Os autores concluíram que: 1) todos os materiais de moldagem produziram modelos de gesso, com diâmetros maiores e alturas menores do que o troquel-padrão; 2) houve poucas alterações na distância entre os troquéis de gesso, comparados com o padrão; 3) a diferenças mais significante foi que a silicona de condensação, produziu, significantemente, modelos menores do que o padrão $(-0,24$ a $-0,37 \%)$, do que as siliconas de adição $(-0,08 \%)$; 4); a mesma precisão foi conseguida para todas as técnicas testadas, quando siliconas de adição foram usadas; entretanto, a técnica massa/fluido foi mais precisa, quando a silicona de condensação foi empregada; 5) os modelos obtidos com moldeiras individuais foram mais precisos $(-0,03 \%)$ na altura do que as de estoques $(-0,15$ a $-0,21 \%)$.

DRUMMOND; RANDOLPH ${ }^{59}$, 1986, estudaram a variabilidade dos modelos resultantes de quatro materiais de moldagem, pelo uso de modelo padrão e pelo tempo de vazamento dos moldes. Um troquel-padrão para coroa total e uma MOD, padronizados pela A.D.A. foram empregados. Um modelo de cera, feito diretamente sobre estes troquéis, foi fundido, e estas restaurações não foram ajustadas, mas foram considerada como uma adaptação marginal ótima. Um cilíndro de plástico foi empregado como espaçador, o que permitia uma espessura ao redor do troquel 
horizontalmente de $3 \mathrm{~mm}$ e, verticalmente, de $5 \mathrm{~mm}$ para a MOD e de $5 \mathrm{~mm}$, horizontalmente, e de $4 \mathrm{~mm}$, verticalmente, para a coroa total. Foram utilizadas moldeiras plásticas, nas quais aplicou-se os respectivos adesivos inerente a cada material, de acordo com o preconizsado pelos fabricantes. Os materiais de moldagem utilizados foram; silicona de condensação (Siccoform), silicona de adição (Methigum), e dois poliéteres (Impregum F e Polygel), todos manipulados de acordo com orientações dos fabricantes. As moldagens, após a polimerização, foram vazadas em três diferentes períodos, uma hora após a remoção do molde e um segundo vazamento, com uma semana após o primeiro vazamento, e vazamento com uma semana após a remoção do molde. As fundições padrões foram assentadas sobre os modelos, com leve pressão dos dedos e examinadas quanto à precisão. Quando a fundição não se assentava completamente sobre o modelo, esta era reembasada com Duralay e, após sua polimerização, removida e feita as medidas da espessura deste em micrometros. As médias das espessuras marginais foram classificadas de 1 a 12, isto é, da menor para a maior. Para as moldagens das coroas totais, as classes de 1 a 6 foram idênticas, mas estatisticamente diferentes das classes, também idênticas de 7 a 12. Para um estudo clínico, somente as moldagens da classe 1 e 2 deveriam ser aceitáveis. Sendo consideradas aceitáveis somente as fundições resultantes dos vazamentos, com uma hora após a remoção do molde.

Os vinilpolisiloxanos ou siliconas de adição, são materiais de moldagem largamente utilizados pelos profissionais, na atualidade, devido às suas propriedade mecânicas precisas e sua fidelidade para a reprodução de detalhes. DHURU et al. ${ }^{58}$, em 1986, avaliaram o retardamento ideal no vazamento dos moldes, para se ter um mínimo de porosidade na superfície, visto que, observações clínicas empíricas têm indicado que modelos de gesso, obtidos destas moldagens, exibem grandes quantidades de poros em suas superfícies, pois há liberação de gazes de hidrogênio, durante a polimerização do material. Fizeram moldagens com Reprosil e Reflect de um manequim, estocando-as em temperatura ambiente de $22 \pm 2^{\circ} \mathrm{C}$, antes do vazamento, os quais foram feitos com 
15, 30 minutos . 1, 2, 4, 8, 12, 24 horas, após a moldagens terem sido removidas . Os modelos foram analisados em um microscópio estéreo com aumento de 10x. Concluíram que: $1^{\circ}$ ) a superfície dos modelos, de ambos os materiais, apresentaram porosidades em todos os intervalos de tempo; $2^{\circ}$ ) uma porosidade mínima foi encontrada, quando os vazamentos se deram em 15 minutos e 24 horas; contudo, a estabilidade dimensional com 15 minutos, mais precisa. Os autores ainda afirmara que o procedimento clínico, mais comummente executado, para evitar essas porosidades, é efetuar o vazamento após várias horas da realização da moldagem; mas advertem que, um armazenamento incorreto das moldagens, resultam em alterações dimensionais, apesar destes materiais apresentarem excelentes propriedades.

Um material de moldagem deveria ser compatível com o gesso dental, para criar um modelo aceitável. A especificação $\mathrm{N}^{\mathrm{o}} 19$, do Instituto Americano de Padronização Nacional e a Associação Dentária Americana ( ANSI/ADA ), especifica o uso do gesso hemi-hidratado não modificado, como determinante de umedecimento nos materiais de moldagem, em compatibilidade com os gessos dentais. Se um linha, com $20 \mu \mathrm{m}$ na superfície do material de moldagem, é reproduzida no modelo de gesso, há compatibilidade do gesso com o material de moldagem. Experiências clínicas indicam que diferentes gessos dentais, com ingredientes modificadores, reagem diferentemente com vários materiais de moldagem. SCHELB et al. ${ }^{132}, 1987$, avaliaram a compatibilidade de cinco materiais de moldagem polivinilsiloxanos, com dez tipos de gesso odontológicos Tipo IV. Foi produzida uma linha de $20 \mu \mathrm{m}$ em 4 placas de vidro, medindo 2 x 2 polegadas, e para as moldagens de suas superfícies, empregaram uma morsa. A placa de vidro - posicionada entre as duas bases de metal da morsa - e entre a placa de vidro e a base inferior, foi colocado uma placa de metal circular e um anel de cobre foi colado para abraçar esta placa, carregada com o material de moldagem. A seguir, a placa de vidro foi posicionada sobre o material de moldagem e pressionada contra o mesmo, até que fizesse contato com o anel, sobre uma carga de 3 onças. A pasta base e a "catalisadora" foram pesadas na proporção de 1:1, e misturadas por 30 
segundo. $\mathrm{O}$ conjunto foi condicionado sobre um banho de água, 3 minutos além do recomendado pelo fabricante. As moldagens foram estocadas à temperatura ambiente, de acordo com o tempo de estocagem, fornecido pelo fabricante. Um anel de cobre largo foi empregado como moldeira. O gesso foi espatulado manualmente por 10 segundo e por 20 segundos a vácuo, sendo introduzido, a seguir, no anel de cobre sob vibração padronizada. O molde vazado, foi deixado, para tomar presa, por 1 hora, em umidade relativa de $100 \%$. Os resultados mostraram que a linha foi reproduzida em todos os moldes, apresentando grande compatibilidade entre os materiais de moldagem e os gessos testados. Os autores sugeriram que, antes de se utilizar um determinado tipo de gesso, com um determinado material de moldagem, sua compatibilidade deveria ser determinada. Salientando que os fabricantes de materiais de moldagem deveriam incluir, junto com as instruções de uso, a indicação de um ou mais tipos de gessos compatíveis.

Segundo McCROSSON et al. ${ }^{104}$, 1987, as siliconas de adição têm largamente superado as siliconas de condensação, devido às suas propriedades superiores. As siliconas de condensação não apresentam ótima estabilidade dimensional, pelo desprendimento de subprodutos alcoóis, na sua reação de cura; as de adição, além de não apresentarem subprodutos, têm melhor precisão. Porém, experiências clínicas têm indicado que modelos vazados nos moldes dos polivinilsiloxanos podem exibir imperfeições que parecem advir de subprodutos, que não podem ser comparadas ao número e forma das porosidades, advinhas de seu pobre umedecimento superficial, pelo gesso. As superfícies de modelos vazados de várias moldagens, empregando polivinilsiloxanos, têm resultado em vário defeitos que impedem o uso do modelo resultante. Quando os modelos vazados para cada tipo de gesso para troquel foram seccionados, não apresentaram nenhuma evidência da porosidade similar na massa dos troquéis. Todavia, das observações nas superfícies dos modelos, fica claro que uma reação ocorre ou com o material da moldagem em si, ou entre este e a presa do gesso, resultando em áreas de porosidades na superfície do 
modelo, que estão em contato com o material de moldagem. Nota-se, também, que os defeitos variam em número; que a ocorrência dos defeitos se deu no intervalo de tempo da polimerização, do material de moldagem e devido ao vazamento do modelo. Os defeitos foram associados aos tipos de siliconas de densidade fluida; contudo, nenhum defeito foi observado no contato da massa com o gesso. Os autores pesquisaram o desprendimento de hidrogênio nos polivinilsiloxanos, visando estabelecer uma relação entre as indicações para o vazamento fornecidas pelos fabricantes e as situações laboratoriais. Os moldes foram vazados com quatro tipos de gesso para troquel, usando as mesmas séries de materiais moldagem e intervalos de tempo similares. Os materiais empregados no teste foram manipulados, de conformidade com as orientações do fabricantes. Após a mistura, $1 \mathrm{ml}$ foi injetado dentro de um frasco de amostra de $5 \mathrm{ml}$ e deixado polimerizar na temperatura ambiente, por 10 minutos. Este intervalo de tempo foi adicionado para o regime de teste, a fim de simular o tempo de presa do gesso em contato com o material de moldagem. Após decorridos 0, 10, 15, 30 minutos e 1, 2, 4,e 6 horas da polimerização dos materiais de moldagem, as amostras foram purificados, analiticamente, com gás hélio puro. A quantidade de hidrogênio presente foi analisada por um espectômetro. Dos resultados obtidos, concluíram que; a quantidade de hidrogênio desprendido foi maior, imediatamente após a mistura ter sido completada e diminuído a seguir, o fato do material empregado, ser uma polivinilsiloxano, não pode ser assumido que este estará completamente livre de subprodutos, advindos da polimerização e que as sugestões dos fabricantes, sobre o tempo de vazamento, deveriam ser seguidas.

PAMENIUS; OHLSON ${ }^{115}$, em 1987, estabeleceram uma correlação entre a força de remoção dos moldes e o comportamento mecânico dos elastômeros. Por meio de um teste laboratorial, na tentativa de simular os procedimentos clínicos, realizaram teste mecânico avaliando a relação força/deformação pela teoria da elasticidade. A remoção do material de moldagem foi realizada por meio de um dispositivo adaptado a uma máquina de ensaio de tração, que registrava simultaneamente a força requerida e o 
alongamento longitudinal. Uma curva típica de separação pôde ser observada quando do teste de tração. Observaram que, à medida que a força era aplicada ocorria uma pequena deformação e que graficamente implicava numa proporcionalidade entre força/deformação até certo ponto. Quando o alongamento aumentava a força diminuía rapidamente para um nível inferior e gradualmente dissipava-se. Este pico foi atribuído a dois fatores: a deformação de cisalhamento do elastômero e a força requerida para superar a pressão atmosférica, que permitiria a penetração de ar na fenda entre o dente e o material de moldagem e conseqüentemente deslocamento do molde. Durante o estágio de deformação elástica, representado pela segunda parte da curva, um estado de tensão prevalece no elastômero. Devido à simetria cilíndrica do espécime, que simulava um preparo tipo coroa total, a concentração de esforços localizava-se ao redor de áreas retentivas, enquanto em outras partes as tensões eram menores e confinadas àquelas partes onde a concentração de esforços estava presente. Estas observações foram possíveis em função da análise fotoelástica. Concluíram que o conhecimento das propriedades elásticas não é suficiente para uma classificação apropriada dos materiais, ou seja, com base na facilidade de remoção. A correlação das propriedades físicas deverá ser elucidada estabelecendo a diferença entre os materiais e o aspecto mecânico durante a remoção da moldagem. Desta forma, a força de remoção requerida para os vários materiais os dispõe numa mesma posição, como observado na prática. A maior contribuição para o conhecimento da energia total provem da força requerida para deslocamento na área retentiva. Uma força excessiva é particularmente inconveniente, mesmo que sua contribuição para a força total seja modesta.

Em uma revisão feita sobre materiais de moldagem, com sete anos de retrospectiva, para CRAIG ${ }^{52}$, 1988, os maiores avanços nos materiais de moldagem e suas aplicações têm ocorrido na última década, com maior ênfase sendo dada aos materiais à base de borracha. Particular interesse tem sido dado ao efeito da solução de desinfecção, nas qualidades das moldagens e para a biocompatibilidade dos materiais. Poliéteres têm sofrido modificaçõe, levando à uma melhora no tempo de trabalho, na 
viscosidade e na flexibilidade e, com a introdução das recentes siliconas de polimerização por adição, as quais possuem uma excepcional precisão. Embora as siliconas de adição liberem hidrogênio, durante a polimerização, retardando o seu vazamento dos moldes, a maioria têm tido melhoras para evitarem esta liberação, assim, moldes podem ser vazados imediatamente. A introdução da manipulação automática, tem reduzido o número de bolhas nas moldagens e a quantidade de material desperdiçado, do mesmo modo, a incorporação de sulfactantes, na composição das siliconas de adição, tem tornado-as hidrofílicas, com propriedade de umedecimento similares aos poliéteres, e tem favorecido vazamentos facilmente livres de bolhas.

Moldagens feitas com materiais elastoméricos têm o seu vazamento dificultado, devido ao seu umedecimento com o gesso, para produção de modelo, resultando em modelos imperfeitos. SCHELB ${ }^{133}$, 1988, relatou que tais modelos apresentam bolhas e imperfeições, decorrentes de vazamento incorreto. Determinadas áreas, tais como: ângulos incisais, margens, caixas, sulcos, concavidades e também preparos com paredes próxima, especialmente nos casos de dentes anteriores, apresentaram dificuldades para o umedecimento de todas essas áreas pelos gessos, sendo comum a ocorrência de imperfeições. Usualmente, os gessos são preparados e vertidos dentro das moldagens, mediante o auxílio de espátulas e vibrações, tornando muito difícil o controle do aprisionamento de ar, que resultará em bolhas nos modelos de gesso. $\mathrm{O}$ autor sugere uma técnica, com o emprego de uma seringa plástica, cujo o objetivo é de introduzir pequenas quantidades de gesso, regulado pelos vários tipos de bico plásticos, conforme a necessidade, associado à vibração. Relata ainda que, os modelos obtidos dessa forma, apresentam-se isentos de bolhas.

Há vários anos, os materiais de moldagem para uso odontológico vêm sendo testados e melhorados em suas propriedades, buscando-se sempre uma maior estabilidade dimensional e uma precisão de reprodução. MENEZES ${ }^{107}$, em 1988, verificou o comportamento dos elastômeros, através de materiais representativos, mais 
comummente usados em clínicas. Comparando o método convencional, de obtenção de moldes e posteriormente troquel, ao método do reaquecimento do molde e outros materiais, a $37^{\circ} \mathrm{C}$, executaram-se 16 moldagens, com cada material, a saber: Unilastic, Xantopren, Impregum F e Provil-L, com a polimerização sempre à $37^{\circ} \mathrm{C}$. Dentre estas 16 moldagens, oito foram para confeccionar troquéis, à temperatura ambiente, e os demais, bem como os materiais, foram mantidos à $37^{\circ} \mathrm{C}$, até o vazamento do gesso e presa final. Os troquéis foram medidos em microscópio comparador e comparados ao troquel-padrão metálico. Após das diferenças encontradas e da análise estatística, foi possível, o autor concluiu que: os troquéis obtidos de moldes reaquecidos, apresentaram uma maior precisão, do que aqueles de moldagens convencionais; sendo que, os materiais que melhor se comportaram, quanto à estabilidade dimensional, foram o Impregum F e o Provil.

Em 1988, ANUSAVICE ${ }^{4}$, publicou um artigo destacando que o desenvolvimento das siliconas de adição foi um dos três maiores acontecimentos ocorridos nas últimas duas décadas, na área de materiais de moldagem. Relatou que o material era biocompatível, apresentava: razoável tempo de trabalho, bom tempo de polimerização, excelentes detalhes de reprodução, aceitável recuperação elástica e baixa contração de polimerização; entretanto, segundo o autor, a principal vantagem deste material era o seu longo tempo de estabilidade dimensional, quando comparado com os hidrocolóides, os polissulfetos, os poliéteres e com as siliconas de condensação. $\mathrm{O}$ autor relacionou como principal deficiência das siliconas de adição, sua natureza hidrófoba. Um campo extremamente seco, seria necessário, para que ela assumisse ótima adaptação ao dente preparado e máximo escoamento, às áreas sulculares adjacentes, outras desvantagem seriam, seu alto módulo de elasticidade e o potencial para liberar hidrogênio, até que o paládio fosse incluído como, absorvedor deste gás. As siliconas de adição, ainda segundo o autor, apresentaram melhoras nas propriedades e características de manipulação; todavia, elas não podiam ser consideradas como ideais, 
devido à sua sensibilidade e às variações de técnicas, embora fossem excelentes e com muitas perspectivas.

EDUARDO; MATSON; FICHMAN ${ }^{62}$, em 1988, verificaram a importância do alívio, feito por meio de casquetes metálicos , com espessuras de 2,5 mm, 1,0 mm e 0,5 mm, para moldagens com três siliconas de condensação, de um troquel metálico padrão que simulava dois preparos, tipo coroa total, em pré-molar e molar, com dimensões e distância definidas. Observaram que o comportamento das moldagens com as três siliconas era diferente em relação aos alívios utilizados, sendo que as moldagens com alívio de 2,5 mm mostraram contração acentuada. As distâncias entre os dois preparos, em função das moldagens, foram diferentes entre si, observando-se diferenças de comportamento do material de moldagem, de acordo com o dente preparado. No prémolar, a distância mésio-distal sendo menor, encontraram contração, enquanto para o molar, a distância mésio-distal sendo maior, observaram expansão, destacando que o comportamento do material de moldagem varia de acordo com o volume do dente preparado, que poderá ser detectável ao nível de trabalho clínico, assim como devem ser consideradas outras variáveis envolvendo a alteração dimensional do gesso para troquel e mesmo da cera utilizada para obtenção do padrão de fundição.

A moldagem com material elastomérico deve estar firmemente aderida à moldeira, para que se obtenha um molde preciso, o deslocamento do material da moldeira durante a sua remoção da boca, resulta em falhas na sua forma e dimensão original, com conseqüente distorção no modelo, padrão de cera e fundição. Para a adesão pode-se usar meios mecânicos ou químicos, tais como; união com material adesivo, furos na moldeira ou a combinação dos dois métodos. BOMBERG et al. ${ }^{26}$, em 1988, analisaram o efeito de alguns fatores de união nas várias combinações de moldeiras e adesivos usados, incluindo o uso ou não do adesivo à moldeira individual de resina acrílica, perfurada ou não e nas moldeiras de estoque. Os melhores resultados obtidos, no que diz respeito à precisão, foram conseguidos quando o adesivo foi 
empregado na moldeira perfurada. A moldeira de estoque perfurada, usada nesse experimento, pode ter tido um valor de retenção devido à quantidade e localização das furos, além do mais, a posição das furos (paralelas ou perpendiculares) afetam os valores de retenção mecânica e devem ser consideradas no desenho da moldeira de estoque ou da individual de resina.

BONACHELA $^{27}$, em 1989 estudou, através da medida do desajuste marginal de coroas fundidas, o comportamento de 5 materiais de moldagem: Provil, Permlastic, Impregum, Xantopren e Jeltrate, empregando a técnica do casquete individual, sendo os moldes vazados, imediatamente, com 24 e 48 horas, após o inicio da espatulação. $\mathrm{O}$ autor concluiu que; $1^{\circ}$ ) no vazamento imediato, o Provil, o Impregum F e o Permlastic, não apresentaram diferenças estatisticamente significantes nos desajustes das coroas; $2^{\circ}$ ) nos moldes, armazenados por 24 horas, o menor desajuste foi atribuído ao Provil, seguido pelo Permlastic; $3^{\circ}$ ) no vazamento dos moldes, após 48 horas, o Provil mostrou-se o mais estável. O autor afirmou que o fator tempo se mostrou significativo, com influência na alteração dimensional dos materiais testados; sendo que o Provil manteve-se praticamente estável em todas, as condições, com Permlastic, vazado, até 24 horas após a obtenção do molde, ocorreu o mesmo, sendo estes materiais indicados para serem estocados nestes períodos.

A precisão de um material de moldagem é uma parte importante na produção de restauração bem acabada e contribui para a longevidade desta. Esta precisão é determinada por uma série de fatores: tais como, contração de polimerização, contração térmica, deslocamento, absorção de água, e desprendimento de água.

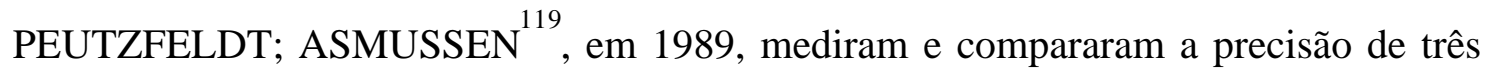
alginatos: Alginoplast, Blueprint e Jeltrate e de sete elastômeros: Baysilex, Deguflex, Express, Impregum, Mirror 3, Permadyne e President. A precisão estudada foi determinada pela contração de polimerização e térmica e, e em se tratando dos alginatos, também a absorção de água. Foram realizadas moldagens de um cone 
truncado, no qual se ajustava um anel de aço e, posteriormente, vazado com gesso. Um anel de aço cônico foi posicionado nos modelos de gesso e a discrepância entre o topo da superfície do modelo de gesso e o do anel foram medidas. Destas medidas, a variação entre o diâmetro da base do troquel e a do cone, foi calculada e usada para expressar a precisão de um material. Os resultados mostraram que em todas as moldagens, houve uma contração relativa, resultando, em troquéis de gesso mais largos e acentamento incompleto do anel de aço. A imprecisão dos alginatos variaram entre 44 e $188 \mu \mathrm{m}$, a dos elastômeros variaram de 39 a $130 \mu \mathrm{m}$. No geral, as siliconas de adição foram mais precisas do que os poliéteres.

Em 1989, ARAÚJO 5 desenvolveu um estudo, para verificar a influência do reaquecimento das moldagens, de silicona de adição e mercaptanas, sobre as fundições em ligas de níquel-cromo. O autor; realizou 20 moldagens para cada um dos dois materiais: Provil e Unilastic, empregando, para tanto, um dispositivo especialmente construído. Os moldes foram vazados com gesso Vel-Mix, sendo que, para 10 moldes de cada material, aguardava-se que os mesmos atingissem a temperatura ambiente, antes do vazamento; os outros 10 moldes, foram vazados à temperatura em que ocorreu a polimerização, ou seja, $37^{\circ} \mathrm{C}$. Os troquéis assim obtidos foram medidos, através de uma coroa frezada de dimensões previamente conhecidas, após o que, foram esculpidos em cera, sobre os troquéis 40 casquete, que por sua vez foram fundidos, seguindo as técnicas atuais de fundições, para metalo-cerâmica. As fundições foram medidas sobre os troquéis de gesso e, em seguida, sobre o troquel metálico original, que serviu de padrão para as moldagens. Concluiu que: as siliconas mostraram resultados superiores aos da mercaptanas; o reaquecimento mostrou-se eficiente, no sentido de incrementar a precisão das moldagens, para ambos os materiais; o processo de fundição não revelou diferenças significantes, entre nenhuma das condições, o que demonstra, que sua variabilidade é maior que a melhoria que se obtém na precisão das moldagens, usandose materiais mais precisos e a técnica do reaquecimento. 
O inadequado escoamento de uma moldagem resulta, segundo PRATTEN; CRAIG $^{125}$, 1989, na incorporações de bolhas de ar nos modelos de gesso. A umidade de uma superfícies é usualmente determinada pelo tamanho da magnitude do ângulo de contato, formado entre uma gota do líquido e a superfície em questão. Neste estudo, os autores compararam a umidade da silicona de adição hidrofílica, recentemente introduzida no mercado, com outros materiais de moldagem elastoméricos. Foram usados poliéter, polissulfeto, silicona de adição hidrofílica e silicona de adição hidrofóbica, em sua habilidade de umedecimento em solução aquosa de $\mathrm{CaSO}_{4} 2 \mathrm{H}_{2} \mathrm{O}$. Todas as moldagens foram realizadas com um bloco plano de resina acrílica, que recebia o adesivo e, posteriormente, o material, vertido sobre uma lâmina Mylar limpa para dar uma superfície plana e polida. Os materiais foram dosados e manipulados de acordo com as orientações dos fabricantes, em temperaturas ambiente de $23 \pm 2^{\circ} \mathrm{C}$, e umidade relativa do ar de $50 \pm 10 \%$. Após os testes de umedecimento, a solução acima, diluída em água, foi usada como solução umedecente. Os moldagens foram vazadas em gesso Vel-Mix, de acordo com a especificação $\mathrm{N}^{0}$ 25, da A.D.A. Os autores concluíram que:; a nova silicona de adição hidrofílica não teve nenhuma diferença significante dos poliéteres; e que uma poderosa correlação negativa foi encontrada entre o ângulo de contato médio e a média verteabilidade do gesso.

ABRÃO et al. ${ }^{2}$, em 1989, estudaram a influência da condição de armazenamento de moldes de mercaptana, nas alterações dimensionais lineares, ocorridas nos moldes de gessos-pedra melhorados, utilizando dois meios de armazenamento: a) à temperatura ambiente de $25^{\circ} \mathrm{C}$. e $55 \%$ umidade relativa, durante 5 minutos; b) em estufa, a $37^{\circ}$ C. e $100 \%$ de umidade relativa, durante 40 minutos. Concluíram que: 1) o meio de armazenamento dos moldes de mercaptana teve influência na alteração linear dos modelos de gesso, pois na condição B, obtiveram modelos com menor alteração linear do que na condição A; 2) a alteração linear dos modelos de gesso variou, conforme a marca comercial dos gessos testados. 
Embora se admita que os materiais elásticos de moldagem, independente de sua composição básica, reproduzam realmente sulcos de 0,025 mm de largura, sabe-se, todavia, que nem todos apresentam características físico-químicas capazes de lhes assegurar, com igual precisão, esses mesmos detalhes para os modelos de gesso. A A.D.A., ao referir-se ao tipo de gesso a ser utilizado com os materiais de moldagem, indica para essa finalidade o sulfato de cálcio hemi-hidratado alfa, não modificado e manipulado na relação proporcional água/pó de 0,30. É uma exigência que não se observa rotineiramente nos laboratórios, uma vez que, para obtenção de troquéis, o material eleito é em geral o gesso-pedra melhorado, por apresentar menor alteração dimensional linear, maior resistência à fratura e maior resistência à abrasão. Para MAZZETTO et al. ${ }^{101}$, em 1990, por não haver um consenso sobre qual seria a melhor combinação material de moldagem/material de modelo, no que se refere à melhor capacidade final de reprodução e transmissão dos pormenores superficiais, estudaram três materiais de moldagem: um polissulfeto (Unilastic), uma silicona de condensação (Xantopren), e um poliéter (Impregum), e seis gessos, sendo dois tipo IV (Vel-Mix e Durone), dois Tipo III (Herodent e Gaúcho), e dois Tipo II (Gaúcho e Mossoró). Da metodologia empregada, os autores concluíram que: 1) todos os materiais de moldagem estudados condicionaram ótimos resultados de detalhes aos moldes; todavia, a combinação desses materiais com os diversos tipos de gessos, determinou níveis diferentes na reprodução de detalhes, sendo, no geral, os piores resultados alcançados pelo Impregum, podendo considerar-se o Xantopren e o Unilastic estatisticamente iguais entre si e melhores do que o primeiro ; 2) os gessos estudados podem, grosseiramente, ser classificados em 4 grupos, conforme os seus níveis médios de reprodução dos detalhes, copiados pelos moldes: Duroc ( média de 2,93 ), o par Vel Mix/Gaúcho III (média de 2,60), o par Herodent/Gaúcho II (respectivamente média de 2,40 e 2,20), e o Mossoró (média 1,53).

As siliconas de adição não são exaustivamente utilizadas pelos dentistas sul americanos, mas sim os polissulfetos. ARAÚJO; JÖRGENSEN; ARAÚJO ${ }^{8}$, em 1990, 
pesquisaram o efeito da associação de reaquecimento e da retenção dos preparos sobre a precisão os moldes de polissulfeto. Moldagens à $37^{\circ} \mathrm{C}$, com o polissulfeto Permlastic $\mathrm{R}$ (densidade regular), foram feitas de troquel de aço crômio, com a forma de um dente preparado para coroa total. Foram usados moldeiras que permitiam uma camada de material de $1 \mathrm{~mm}$ e outra de $4 \mathrm{~mm}$ de espessura, na região cervical do preparo. Os vazamentos foram executados após o resfriamento do molde a $22^{\circ} \mathrm{C}$, por 10 minutos, e após o resfriamento do molde a $22^{\circ} \mathrm{C}$ por 10 minutos e posterior reaquecimento, a $37^{\circ}$ C, por 30 minutos. Do reaquecimento, segundo os autores, foram obtidos modelos de gesso com maior precisão, sendo possível a obtenção de troquéis com um mínimo de alterações das dimensões do dente preparado, pelo reaquecimento dos moldes e pelo uso de gesso com expansão de presa desejáveis.

O efeito do reaquecimento e a retenção do preparo, sobre a precisão dos moldes de uma silicona de polimerização por adição (President, regular), foi analisado por ARAÚJO; JÖRGENSEN; ARAÚJO9 ${ }^{9}$, em 1990. A ação do reaquecimento dos moldes, segundo os autores, determinou maior precisão dos modelos de gesso e as retenções têm uma influência definitiva mas pequena, sobre a precisão dos moldes de silicona de adição.

A melhor combinação do material de moldagem e do gesso para troquel deve reproduzir, em detalhes, o preparo e fundição resultante, com maior precisão. Portanto, a compatibilidade do gesso e do material de moldagem estão diretamente relacionados à quantidade de detalhes reproduzidos no troquéis. OMANA et al. ${ }^{114}$, em 1990, fizeram um estudo piloto, testando a compatibilidade de 4 materiais de moldagem: polivinilsiloxanos, com 11 diferentes gessos para modelo. As diferentes combinações foram comparadas uma às outras, quanto a sua habilidade de reprodução de sulcos de $6 \mu \mathrm{m}$ e $17 \mu \mathrm{m}$, inscritos em um bloco de aço inoxidável. O grau de compatibilidade das várias combinações de material de moldagem/gesso foram diferenciados, pelo uso de um analisador de traçados, que media a profundidade e 
reprodução dos sulcos nos modelos de gesso. Estes dados foram, então, comparados com os do bloco metálico, observando se havia alguma vantagem no uso de uma combinação de material de moldagem/gesso sobre outra. Baseados neste estudo piloto, os clínicos podem acreditar que todos os polivinilsiloxanos, analisados, mostraram um resultado aceitável na reprodução de um preparo. Maiores precisões podem ser conseguidas, quando há uma seleção cuidadosa de uma combinação material de moldagem/gesso. Outros fatores tais como: características de trabalho, de cor, e sistema de emprego destes materiais devem ser meramente uma preferência pessoal.

Para CHONG et al. ${ }^{42}$, 1990, os materiais de moldagem elastoméricos possuem uma capacidade de umedecimento pobre, resultando em modelos de gessos com inúmeros defeitos na superfície. Os autores examinaram a relação existente entre os ângulos de contatos dos modelos de gesso e as bolhas, produzidas nos modelos de cinco materiais de moldagem de média viscosidade: 2 siliconas de adição hidrofílica, 1 silicona de adição e 1 poliéter. As medidas dos ângulos, formados pelos materiais, foram feitas em microscópio e os valores dos ângulos de contatos, encontrados nas siliconas de adição, foram significantemente maiores do que nos poliéteres, mas menores do que outras siliconas. A correlação entre os valores dos ângulos de contatos encontrados com o número de bolhas achadas, nas margens e linhas de ângulos dos modelos de gesso, não foi semelhantes às bolhas encontradas na superfície polida do gesso. Relataram ainda que, em estudos anteriores, substâncias de umedecimento, quando aplicadas sobre a superfície dos materiais de moldagem, apresentaram um aumento na capacidade de umedecimento, podendo promover efeitos adversos nestes materiais. Para que se obtenha uma superfície lisa, com um número reduzido de bolhas, deve-se acondicionar o gesso em seringas para levá-lo nos moldes, tomando-se o cuidado em padronizar a duração e a magnitude da vibração, deixando sempre a moldagem na posição horizontal até a presa final do gesso. 
Em 1990, GORDON et al. ${ }^{70}$, avaliaram a precisão de reprodução de modelos de gesso, feitos de moldes com siliconas de adição, polissulfeto e poliéter, usando moldeiras confeccionadas com os materiais resina acrílica, termoplástico, e um plástico . As moldagens foram feitas a partir de um troquel-padrão de aço, o qual simulava um preparo para coroa para uma prótese parcial fixa. Os moldes foram vazados, após uma hora, em gesso tipo IV. Os resultados indicaram que as moldeiras, feitas com resina acrílica e com o termoplástico, tiveram performance similares, em relação à precisão dos modelos e produziram troquéis clinicamente aceitáveis, sendo que as moldeiras confeccionadas com plástico tiveram maior alterações dimensionais do que as outra duas.

A resistência ao rasgamento dos materiais de moldagem são de interesse tanto do dentista como do técnico em prótese dental. Clinicamente, é crucial que o material de moldagem não se rompa, quando da sua remoção da boca. Similarmente, a produção de um segundo vazamento preciso, depende parcialmente desta operação. TAM; BROWN ${ }^{145}$, em 1990, estudaram a resistência ao rasgamento de vários materiais de moldagem com e sem modificadores. Foram testados 15 materiais de moldagem: dois polissulfetos, três poliéteres e dez siliconas de adição, destes, em quatro siliconas e dois poliéteres foram adicionados, sistemas modificadores. Os materiais foram dosados e manipulados, de acordo com as recomendações dos fabricantes, em temperatura ambiente de $22 \pm 2^{\circ} \mathrm{C}$. Moldagens de um molde metálico, com um formato em $\mathrm{V}$ bem definidos, foram realizadas. O material foi comprimido entre o molde metálico e uma placa de vidro, ambos pré-condicionados a $37 \pm 2^{\circ} \mathrm{C}$, por dois minutos, após a mistura estar completada. O tempo de polimerização de 1 minuto foi sugerido pelo fabricante. Porém, alguns materiais tiveram polimerização incompleta, neste tempo e um tempo adicional, foi acrescido, até se conseguir a polimerização. Os moldes foram testados em um máquina de teste, que mantinha uma temperatura de $37 \pm 2^{\circ} \mathrm{C}$. Os resultados mostraram que; nenhum dos materiais testados, apresentaram superioridade na resistência ao rasgamento. Como um grupo, de materiais monofases, fracassaram, ao 
demonstrar uma superioridade na resistência ao rasgamento, sobre os de alta viscosidade, retardadores e tinners, reduziram a resistência ao rasgamento, no valores dos materiais testados. Para cinco dos seis materiais, a redução na resistência ao rasgamento foi significante.

As propriedades de algumas marcas comerciais de materiais de moldagem, recentemente lançadas no mercado, foram comparadas com os produtos mais utilizados nos últimos cinco anos por CRAIG et al. ${ }^{53}, 1990$, com a finalidade de fornecer ao clínico, base para a seleção de produtos para aplicações específicas. Desta pesquisa afirmou que; dos 25 produtos de consistência variadas, destacaram, que as siliconas de adição Exaflex H e Hydrosil H (com características de hidrofilicidade), apresentaram um ângulo de contato com a água, por volta de $50^{\circ} \mathrm{C}$. O tempo de trabalho decrescia, do poliéter uretano dimetacrilato, polissulfeto, silicona de adição de manipulação manual, silicona de condensação, poliéter e silicona de adição auto manipulados. $\mathrm{O}$ tempo de trabalho do poliéter uretano dimetacrilato é ilimitado, quando não exposto à luz azul, o pequeno tempo de trabalho das siliconas de adição auto manipulados, são compensados pelo tempo zero de manipulação, quando comparados com os tempos de manipulação manual de 30-45 segundos dos materiais de moldagem. A recuperação da deformação do polissulfeto, foi o mais elevado e, menor para as silicona de adição de manipulação manual; esta quando comparada como os grupos das siliconas de condensação, poliéter, e siliconas de adição auto manipuladas, usualmente, teve valores intermediários. No geral, os polissulfetos, foram mais flexíveis do que os outros materiais . Os testes de alterações dimensionais, foram divididos em dois grupos: os polissulfetos e as siliconas de condensação, foram os grupos com maiores alterações e, os outros grupos, das siliconas de adição e dos poliéteres, com baixa alterações dimensionais. No geral os moldes vazados com um hora, foram mais precisos do que os vazados com uma semana. 
Embora as siliconas de condensação apresentem subprodutos, em sua reação de cura, elas são largamente utilizadas e, quando se segue todas as especificações, os resultados finais, para se obter modelos de trabalho são satisfatórios. Em 1990, LIBANORI; EDUARDO ${ }^{92}$ apresentaram um trabalho, cujo objetivo era mostrar a evolução das siliconas de adição e, por esta razão descreveram sua composição, suas técnicas de moldagem e sua evolução. As siliconas de adição, também conhecidas como polivinilsiloxano, onde o grupamento de polímero, apresentam ligações cruzadas com os grupamentos silânicos, ativados por um sal de platina, catalisado em reação de adição. Não apresentam subprodutos, como acontece com as siliconas de condensação. São materiais que não necessitam de moldeiras especiais, podendo ser empregadas em moldeiras individuais ou moldeiras de estoque. Para os autores, o uso de adesivo, associados à moldeiras mais adequadas ao caso a ser moldado, constitui a melhor opção para uma moldagem precisa. As técnicas de moldagem, para os elastômeros, são dependentes do tipo de material utilizado e de sua consistência: pesado ou "massa", regular, leve e fluido. Concluíram que a grande vantagem das siliconas de adição é a não liberação de subprodutos, em sua reação de cura, conferindo-lhe uma melhor estabilidade dimensional.

Os polissulfetos são usados para moldagens de próteses parciais fixas. Estes materiais fornecem reproduções com excelentes detalhes, quando suas paredes, que entram em contato com os gessos estão secas. WALTERS; SPURRIER ${ }^{150}$, em 1990, estudaram o efeito do desenho da moldeira e moldeiras modificadas nas alterações dimensionais lineares, em moldagens feitas com polissulfetos. Para determinar qual desenho era menos restritivo, testaram uma moldeira convencionalmente confecciona em três modificações e uma moldeira de estoque com retenções nas bordas com duas modificações. Controlaram, com atenção, o volume do material de moldagem pelo uso de dosagem pré-determinada. Cada moldeira foi carregada até a sua metade, na direção ocluso-gengival. Os excesso foram ajeitados com os dedos nas bordas da moldeiras, após a colocação do material com seringa nos suportes. As moldagens permaneciam na 
boca do paciente por 12 minutos, e após este tempo, eram removidas e deixadas para descansar por 15 minutos, antes do vazamento. Os moldes foram vazados com gesso Tipo IV e separados após 1 hora, quando foram deixados para secar por 24 horas. Para cada uma dos 25 modelos de gesso, distorções dimensionais foram registradas nas superfícies mesio-distal, buco-lingual e ocluso-gengival. Com o uso de um compasso calibrador, foram feitas as medidas nas bocas dos pacientes e comparadas com as dos modelos, a fim de se determinar as distorções. Os autores concluíram que: 1) uma quantidade controlada de adesivo e de materiais de moldagem, em um novo desenho para as moldeiras individuais, devem ser utilizadas para diminuir as distorções; 2) quando estes fatores são controlados, resultam em moldagens melhores e em modelos de trabalhos mais precisos. Como resultado tem-se um melhor assentamento das próteses parciais fixas, na boca.

LEWISTEIN; CRAIG ${ }^{91}$, 1990, objetivando introduzir um método diferente para avaliar a precisão dos materiais elastoméricos de moldagem, utilizaram um calibrador, para medir a altura vertical dos troquéis de gesso e para determinar as alterações verticais e horizontais de quatro materiais de moldagem por meio de gabaritos metálicos. Medidas comparativas demonstraram mudanças para as siliconas de adição e de condensação; grandes alterações para o sistema combinado hidrocolóide/alginato e para o material polimerizado por luz (poliéter uretano metacrilato). As menores alterações ocorreram, quando foram usadas moldeiras de estoque inferiores, na maxila superior, com o emprego da técnica massa/fluido. Salientaram que a avaliação da precisão de materiais de moldagem, utilizando troquéis de gesso, expressando os dados em percentagem, resultam em afirmações incorretas; razão pela qual preconizam uma analise tridimensional desses troquéis.

A estabilidade dimensional é uma das especificação incluídas pela Associação Dentária Americana, para os materiais de moldagem elastoméricos. Mas as características dos materiais são analisadas individualmente, em outra palavras, os 
materiais fluidos, médios, pesados e massas são investigados separadamente e não em formas combinadas, como são normalmente usados pelos clínicos. PETERSEN; ASMUSSEM $^{118}, 1991$, pesquisaram 7 materiais elastoméricos de moldagem, usando a técnica da dupla mistura, que consiste no uso de um material de baixa e o outro de alta viscosidade do mesmo produto. Para maior precisão os materiais foram manipulados e dosados, de acordo com as instruções dos fabricantes sendo eles polimerizados um sobre o outro. Os estudos foram divididos em duas partes; A) as distorções foram qualificadas; B) as possíveis explicações das distorções foram avaliadas. Todo o trabalho foi realizado em temperatura e umidade relativa ambiente. As distorções ocorridas, nas combinações de materiais de alta e baixa viscosidade, foram mensuradas através de um microscópio de leitura por luz e diferenças significantes entre os materiais foram observadas. O fenômeno pode ser explicado pela expansão do material de baixa viscosidade. A expansão pode ser associada à difusão de componentes não reagidos dos materiais de alta viscosidade, dentro do material de baixa viscosidade. Medidas da expansão dos corpos de prova, imersos em componentes do catalisador de outro material do mesmo conjunto, mostraram um aumento no tamanho de $2-5 \%$.

Idealmente, troquéis para confecções de restaurações deveriam ser réplicas exatas dos dentes preparados. Para se conseguir estas metas, o material de moldagem e o gesso dental deveriam ter características compatíveis. A reação de presa dos gessos dental resultam em um expansão. A especificação $\mathrm{N}^{\mathrm{o}} 25$, da A. D. A., limita a expansão de presa do gesso dental Tipo IV em 0,1\%, como a máxima aceitável . PRICE et al. ${ }^{126}$, em 1991, mediram a alteração dimensional absoluta que ocorre em três áreas dos troquéis de gesso, usando quatro materiais de moldagem: Express, Perfourm, Extrude e Impregum F, e três marcas comerciais de gessos Tipo IV: Supra Stone, Die Keen e Silky Rock. Como modelo padrão, foi confeccionado um troquel metálico fundido, no qual foram feitos furos, com uma broca $\mathrm{n}^{\mathrm{o}} .2$, nas faces bucal e oclusal. Uma moldeira de acrílico foi fabricada, de modo a permitir um espaço entre o troquel metálico e a moldeira de $4 \mathrm{~mm}$. Os materiais de moldagem foram manipulados, de acordo com as 
recomendações dos fabricantes, sendo que, ainda, foi passado adesivo nas superfícies internas das moldeiras. As moldagens foram executadas e deixadas por 10 minutos, à temperatura ambiente de $22 \pm 1^{\circ} \mathrm{C}$, para polimerizarem. Os moldes foram vazados e deixados por 1 hora para a presa do gesso. As distâncias entre os furos dos troquéis de gesso foram medidas em microscopia. Os autores concluíram que: 1) todos os troquéis de gesso foram maiores do que do padrão metálico; mas o aumento no tamanho foi pequeno; 2) apesar de existirem diferenças significantes entre algumas combinações de material de moldagem/gesso, todos os troquéis de gesso tiveram diferenças: menos de 9 $\mu \mathrm{m}$ um do outro; 3) nenhuma combinação do material de moldagem/gesso produziram consistentemente troquel maior ou menor, nas três direções avaliadas: altura, largura ou comprimento.

A entrada de bolha de ar, quando introduzimos o gesso no molde, pode resultar em substancial defeito na fundição final. Embora a viscosidade e a tensão superficial do gesso dental não possam ser alterados, sem o comprometimento de outras propriedades físicas, diferentes materiais de moldagem exibem diferentes umectantes. CHAI; YEUNG ${ }^{37}$, 1991, fizeram uma revisão de literatura, em relação à umidade e adesão, e relataram as conclusões no umedecimento de vários novos materiais de moldagem hidrofílicos. Segundo os autores, pode-se concluir que: 1) a variação do tempo entre 20 e 80 minutos, após o início da mistura, não afeta o umedecimento dos materiais de moldagem testados; 2) o poliéter, ativado por luz, mostrou-se no geral melhor umedecimento; mas não foi significantemente diferente dos outros poliéteres testados; 3) os polivinilsiloxanos não hidrofílicos exibiram um menor umedecimento significativo do que os polivinilsiloxanos hidrofílicos, poliéteres e do poliéter ativado por luz; 4) o polivinilsiloxano denso demonstrou o menor umedecimento do que todos os outros materiais testados.

Uma das maiores frustrações na odontologia são restaurações que não se adaptam aos preparos. Na polimerização dos materiais de moldagem, a moldeira é 
fletida para fora, podendo um stress residual nela permanecer, causando uma deformação na remoção do molde e resultando em modelos indesejáveis. WASSELL; IBBETSON $^{151}$, 1991, compararam a precisão do molde, cuja moldagens foi feita pela técnica de um estágio (sanduíche), com os materiais de moldagem polivinilsiloxanos PL (massa/fluido) e HL (denso/fluido), quando usados com moldeiras de estoques de duas propriedades elásticas, sendo algumas moldeiras reforçadas com resina acrílica. $\mathrm{O}$ efeito do reforço das moldeiras, no resultado e precisão dos modelos, também foram examinados. Moldagens feitas com o PL, em ambos tipos de moldeiras, resultaram em dimensões buco-linguais menores nas linhas de término dos preparos; entretanto, reforços das moldeiras com acrílico reduziram esta distorções. Imprecisões significantes na região de segundo molar, foram obtidas em todas as moldeiras. Quando do uso da moldagem com PL, estas distorções devem resultar em troquéis clinicamente inaceitáveis. Moldes com HL produziram modelos com alta precisão na região crítica, independente dos tipos de moldeiras. As distorções foram reduzidas nas moldagens tanto com PL ou HL; mas não eliminadas, quando houve reforço das moldeiras.

CHAI et al. ${ }^{38}$, em 1991, investigou a resistência à tensão de união de cinco sistemas de adesivo para materiais de moldagem. Os materiais empregados foram o poliéter, polivinilsiloxano pesado e o de média viscosidade, um polissulfeto e uma silicona de condensação empregou-se neste estudo moldeiras de resina acrílica autopolimerizável e de poliestireno. Os resultados mostraram diferença não significativa entre os 4 primeiros materiais testados com relação a adesão à moldeira de resina; o poliéter e o polivinilsiloxano de média viscosidade apresentaram um adesão significativamente alta à moldeira de poliestireno, o polissulfeto e a silicona de condensação aderiram bem melhor à moldeira de resina acrílica, enquanto o polivinilsiloxano não apresentou união a estes adesivos, sendo a adesão deste material à moldeira inteiramente mecânica. 
Quando os materiais de moldagem polivinilsiloxanos foram introduzidos no mercado, algumas propriedades desejadas foram notadas, além do que sua natureza hidrofóbica resultou em modelos e troquéis de gesso, com superfícies porosas. PANICHUTTRA et al. ${ }^{116}$, 1991, avaliaram três materiais de moldagem polivinilsiloxano hidrofílicos que continham um surfactante intrínseco (Express, Mirror 3 - Extrude e Reprosil), em suas propriedades de precisão dimensional linear, umedecimento, e efeito na dureza do gesso, quando comparados a um polivinilsiloxano hidrofóbico (Perforum), com e sem sulfactante tópico e um poliéter (Impregum F). Para a padronização de homogêinização, todos os materiais foram manipulados com o uso de uma seringa de auto mistura, fornecida pelos fabricantes dos materiais testados. Os resultados mostraram que: 1) o polivinilsiloxano hidrofóbico foi mais preciso do que o hidrofílico, em duas das três medições; mas as diferenças foram pequenas; 2) o poliéter foi o mais umectante, e o polivinilsiloxano hidrofílico foi mais do que o hidrofóbico, porém, quando sulfatantes tópicos foram usados, não houve diferenças de umectação entre o polivinilsiloxano hidrofílico e o hidrofóbico, e sua propriedades umectantes foram comparadas ao poliéter, indicando que o sulfactante tópico foi mais efetivo do que o intrínseco; 3) os modelos de gesso, obtidos dos polivinilsiloxanos hidrofóbicos, foram mais duros do que o obtidos com os outros materiais de moldagem.

Estão envolvidos numerosos fatores para que se obtenha modelos ou troquéis de gesso precisos e livres de bolhas. O relacionamento do material elastomérico de moldagem e sua interação com o gesso úmido é um fator importante. CULLEN et al. ${ }^{54}$, em 1991, fizeram um estudo para: determinar o ângulo de contato e a relativa capacidade de umedecimento de vários materiais de moldagem e para comparar a sua relação com modelos de gesso com bolhas, obtidos dos moldes. Os resultados obtidos demonstraram que; os materiais elastoméricos, modificados pela adição de sulfatantes (agentes tensoativos) pelos fabricantes, são mais hidrofílicos do que os não sulfatados, pois nestes os ângulos de contato da água com o elastômero estão aumentados, com isto há dificuldade na obtenção de modelos, livres de bolhas, que 
também aumentam. Sulfatantes laboratoriais, aplicados tanto quanto os elastômeros chamados hidrofílicos, são mais efetivos, pela redução da natureza hidrofóbica dos elastômeros, aumentando a probabilidade de se obter modelos de gesso, livres de bolhas.

$\mathrm{SOH} ; \mathrm{CHONG}^{139}$, em 1991, investigaram a presença de bolhas na moldagem de cinco siliconas de adição de manipulação automática. Para tanto, executaram moldagens, de um cilindro de aço inoxidável, com a técnica massa/fluido e utilizaram um espaçador acrílico, para permitir uma espessura de material de moldagem de $3 \mathrm{~mm}$. Os materiais foram proporcionados e manipulados, de acordo com as instruções dos fabricantes. O número de bolhas foram contados, em um lado prédeterminado, em três dias diferentes, empregando-se um microscópio com um aumento de 7x. Corpos de provas de silicona de adição, de manipulação manual, e de manipulação automática, mas manipulada manualmente, serviram como comparação. Express resultou, significantemente, um maior número de bolhas do que os outros materiais de manipulação automática, sendo que, o President Jet teve o menor número de bolhas contadas. Materiais de moldagem de manipulação automática, geralmente, produz moldagens, significantemente, com menor número de bolhas do que os materiais de manipulação manual. A auto mistura foi efetiva na redução de defeitos por bolhas nas moldagens elastoméricas.

Para um material de moldagem ser compatível ao gesso, a especificação $\mathrm{N}^{\mathrm{o}}$ 19, da ANSI/ADA, requer que uma linha na superfície do material de moldagem seja reproduzida na superfície do gesso dental, de composição não modificada. SCHELB et al. $^{134}$, em 1991, investigaram a reprodução dos detalhes da superfícies de quatro siliconas de adição (Absolute, Reprosil , Cinch-Vinyl e Express), com 14 marcas comerciais de gesso dental Tipo IV (APL, Fuji Rock, Die Keen, Indic Die Stone, Diestone, Vel Mix, Supra Stone, Duroc, Glasstone, UTK Blue, Yellow Prima Rock, Jade Stone, Violet Silky Rock e SuperCal). Cada combinação de material de moldagem 
e gesso dental foram usados para duplicar, através de um dispositivo especial uma linha de $20 \mu \mathrm{m}$. Os autores concluíram que; 1) a capacidade de reproduzir uma linha de 20 $\mu \mathrm{m}$, variou entre as combinações das siliconas e gessos; 2) a combinação Absolute/Jade Stone reproduziu a linha $100 \%$ das vezes; enquanto $21 \%$ das combinações silicona/gesso não reproduziram as linhas todas as vezes. 3) as linhas foram reproduzidas em todas as moldagens; mas somente em 32\% dos modelos de gesso; 4) 12 combinações não reproduziram, de algum modo, as linhas.

Em 1991, BONACHELA ${ }^{28}$ verificou as alterações dimensionais em sete diferentes marcas comerciais de gesso: sendo seis do tipo IV (Suprastone, Durone, Glastone, Polirock, Herostone e Vel-Mix) e uma do tipo III (Rapid Stone), quando provenientes de moldes de uma silicona de adição (Provil H). O autor realizou inicialmente 70 troquéis de gesso, sendo 10 para cada marca comercial, utilizando-se de um dispositivo especial para moldagem e análise dos desajustes. Estes foram medidos através de um anel de medição em microscópio de profundidade, onde foram encontradas diferenças entre os materiais empregados. Numa segunda fase, 42 novos troquéis receberam ceroplastia e peças fundidas em ligas de níquel-cromo foram obtidas. Os desajustes foram, agora, medidos sobre o troquel-padrão de aço, sem que estas sofressem qualquer tipo de usinagem. Pôde-se identificar peças mais precisas, provenientes de gesso Vel-Mix (tipo IV), com um menor desajuste; e peças, provenientes do Herostone (tipo IV), com um maior desajuste.

Superfícies porosas, em áreas críticas tais como: margens e linhas de ângulos, podem afetar a assentamento final da restauração fundida. O sistema de espatulação automática foi introduzido para contornar o problema, associado à espatulação manual dos materiais de moldagem. CHONG et al. ${ }^{43}$, em 1991, examinou a formação de bolhas, nos moldes de cinco siliconas de adição automanipuláveis, preparados por manipulação automática e manual, comparando a uma silicona de adição de manipulação manual, pela contagem das bolhas produzidas pela moldagem. 
Os resultados mostraram que nenhuma das técnicas produziram moldes completamente livres de bolhas, pois o material de manipulação manual, utilizado neste estudo, portouse tão bem quanto os auto manipuláveis; todavia, alguns materiais de moldagem, com manipulação automática, produziram significantemente menos bolhas do que outros, indicando que certos materiais de auto manipulação são melhores do que os outros.

A recente proliferação no número de materiais elastoméricos de moldagem automanipuláveis atestam a sua grande popularidade. Para simplificar o procedimento de moldagem, os fabricantes introduziram um bico intra-oral, posicionado na ponta da seringa de manipulação e, com isto, o material é levado diretamente no dente preparado, eliminando a necessidade da seringa de moldagem. Em 1992, LIM et al. ${ }^{93}$ avaliaram o efeito da variabilidade do operador, no número de bolhas, produzido na moldagem pelo sistema de auto mistura, com e sem o uso do bico intra-oral ou da seringa de moldagem. O material de moldagem de mistura manual também foi utilizado para comparação. Os resultados mostraram não haver nenhuma diferença entre os sistemas testados, visto que o sistema de auto mistura produziu substancialmente menos bolhas do que o de manipulação manual. Não houve diferenças significantes entre os números de bolhas, nas moldagens dos dois operadores.

Tem sido largamente aceito que as siliconas de condensação são dimensionalmente menos estáveis do que as siliconas de adição, devido à liberação de álcool, como subprodutos na reação de polimerização, contribuindo substancialmente para a contração global. Em 1992, BRADEN ${ }^{31}$ estudou a contração linear por 24 horas, após a polimerização de 9 siliconas de condensação. A perda de peso e mudanças no volume foram avaliadas em corpos de provas do mesmo material e ao mesmo tempo, em condições similares na água e no ar. $\mathrm{O}$ autor concluiu que para todos os materiais testados, exceto paro os excessivamente densos, o correspondente entre os dados experimentais e teóricos foram razoáveis. No caso dos materiais densos, a contração foi 
muito maior do que o prognosticado teoricamente, isto é possível devido ao efeito conseqüente da memória elástica, nos moldes de materiais pesados.

Atualmente os materiais, à base de polivinilsiloxanos, foram introduzidos no mercado odontológico, especialmente formulados para a confecção de moldagens, em um único passo, pela técnica de moldagem da simples mistura. Além de ser uma técnica de fácil execução, pode-se lançar mão do uso de moldeiras de estoques. TJAN et al. ${ }^{144}, 1992$, estudaram o efeito do espaço existente para o material de moldagem na moldeira e em repetidos vazamentos, por variados intervalos de tempo, na estabilidade e precisão dimensional dos polivinilsiloxanos, por dois métodos; a) medição das mudanças lineares, nas dimensões dos modelos de gesso (método quantitativo) e b) medição visual, baseado na precisão do assentamento da coroa-padrão, no modelo de gesso (método qualitativo). Os autores empregaram quatro marcas de polivinilsiloxanos (Baysilex, Detaseal, Hydrosil XT e Imprint), para a confecção de moldagens de um troquel-padrão metálico, o qual simulava uma Prótese Parcial Fixa de três elementos. Foram empregados como continentes, três tamanhos diferentes de moldeiras, que possuíam 2, 4 e $6 \mathrm{~mm}$ respectivamente de espaço, entre as paredes internas da moldeira e as externas do troquel-padrão. As moldagens foram feitas com os materiais dosados e espatulados, de acordo com as orientações dos fabricantes. Uma fina camada de adesivo, do respectivo material a ser moldado, foi pincelado nas moldeiras. Durante a moldagem, a temperatura ambiente era de $22^{\circ} \pm 2^{\circ} \mathrm{C}$ e umidade relativa do ar de $50 \pm$ $5 \%$. Uma hora após as moldagens terem sido realizadas, elas foram vazadas com gesso Die Kem, e revazadas com 24 horas e 7 dias. Os autores concluíram que, no geral, a avaliação de ambos os métodos (quantitativo e qualitativo), indicaram que os espaços internos das moldeiras, tanto quanto os revazamentos, não afetaram a estabilidade e a precisão dimensional dos materiais de moldagem empregados. Porém, as medidas da interpretação dimensional, sugeriram um possível problema potencial na fundição de uma peça de Prótese Parcial Fixa, devido à redução significante na distância entre os retentores. 
Para CHEE; DONAVAN ${ }^{39}$, 1992, os materiais de moldagem do tipo polivinilsiloxanos têm se mostrado com excelentes propriedades, contudo, possuem variáveis manipulativas e sensitivas. Vários métodos são descritos na literatura, para o emprego desses materiais de alta viscosidade (massa) para formar um moldeira, permitindo uma uniformidade do material de baixa viscosidade (fluido). As desvantagens destas técnicas, segundo os autores são que; $1^{\circ}$ ) não se tem o controle da espessura do material; $2^{\circ}$ ) parte dos detalhes dos dentes preparados são registrados pelo material de densa viscosidade; sendo que, a maioria dos materiais densos, não obedecem às especificações de $\mathrm{N}^{\circ} 19$, da A. D. A.; $3^{\circ}$ ) possuem pouco tempo de trabalho. Outro problema, sugerido é o da interação do polivinilsiloxano com os materiais usados para a confecção de luvas de látex, o que inibem a polimerização deste.

A fim de testar a elasticidade dos materiais elastoméricos de moldagem um estudo sobre a temperatura de polimerização do material, sobre o tempo e força de deformação, durante a remoção da boca, e sobre a espessura que o material deve ter BLOMBERG et al. ${ }^{24}$, em 1992, desenvolveram uma pesquisa para determinar os parâmetros acima. Os materiais elastoméricos, utilizados na pesquisa, foram: polissulfeto (Permlastic H), Silicona de condensação (Delicron M), poliéter (Impregum M) e um polivinilsiloxano (Reflect M). Estes materiais foram manipulados de acordo com as instruções do fabricantes. Para se avaliar a temperatura de polimerização, o estudo foi dividido em duas partes : A) avaliações clínicas e B) estudo in vitro, para avaliar a temperatura durante a polimerização. A média de tempo, gasto para um grupo de operadores removerem este tipo de moldagem da boca, foi de 5 segundos. Nas moldeiras individuais, com materiais de viscosidade médias e pesadas, a camada de material foi de somente $0,15 \mathrm{~mm}$ de espessura e, essencialmente, o material de viscosidade densa forneceu os componentes elásticos para o molde. Para os materiais polissulfeto, silicona de condensação e de adição, a temperatura final dos moldes 
corresponderam à temperatura da região dos incisivos e, para o poliéter, representou uma média entre a região dos incisivos e dos molares.

PHILLIPS $^{121}$, em 1993, destaca que o material de moldagem ideal seria alguma substância suficientemente elástica para ser removida de áreas retentivas e retornar à forma original sem distorções. Os elastômeros seriam primordialmente indicados nas moldagens dos dentes, nas quais a elasticidade é um pré-requisito necessário. Relatam o método de avaliação da precisão dos materiais de moldagem que utilizam troquéis de aço padrões, que simulam preparos cavitários, aos quais se adaptam perfeitamente fundições padrões. A moldagem do troquel padrão e o vazamento com gesso especial para troquel permitem a avaliação do desajuste da fundição padrão ao troquel de gesso, sendo justificado ignorar-se qualquer alteração dimensional do gesso. Dentre as falhas comuns e suas causas nas moldagens com elastômeros, citam que a distorção dos moldes poderia ser causada pela contração de polimerização continuada da resina da moldeira e pela falta de adesão a ela, pela espessura excessiva e não uniforme dos elastômeros, por movimentos da moldeira durante a polimerização e pela remoção prematura ou inadequada do molde da boca.

TEIXEIRA $^{146}$, em 1993, desenvolveu um trabalho para verificar as alterações dimensionais de troquéis de gesso tipo IV, obtidos a partir de seis materiais elastoméricos (Provil-L, Xantopren, Silon-F, Permlastic, Unilastic e Impregum), variando-se a espessura destes materiais ( 1 e $4 \mathrm{~mm}$ ), assim como a temperatura no ato do vazamento $\left(22^{\circ}\right.$ e $\left.37^{\circ} \mathrm{C}\right)$. Como modelo para as moldagens, foi empregado um troquel metálico cônico, utilizando-se um dispositivo de moldagem especialmente construído para isso e obtendo-se, assim, 20 moldagens com cada material. Os vazamentos foram efetuados: sendo 10 moldes de cada material, obtidos e vazados a $37^{\circ} \mathrm{C}$, outros 10 , obtidos a $37^{\circ} \mathrm{C}$ e vazados a $22^{\circ} \mathrm{C}$. Os diâmetros cervical, médio e oclusal dos troquéis de gesso foram medidos ao microscópio comparador e as medidas foram comparadas com a do troquel-padrão. Após a análise estatística, o autor concluiu 
que: $1^{\circ}$ ) o aumento na espessura do material de moldagem influi negativamente na fidelidade do molde, independentemente do material e temperatura utilizados; $2^{\circ}$ ) o reaquecimento dos moldes, a $37^{\circ} \mathrm{C}$, possibilitou a obtenção de troquéis de gesso mais fiéis; quando comparados com aqueles obtidos a temperatura ambiente $\left(22 \pm 2^{\circ} \mathrm{C}\right)$. O Permlastic foi o que melhor se apresentou entre os materiais testados, seguido pelo Impregum F e Provil L.

A busca pela execução de peças fundidas que se adaptem perfeitamente aos dentes preparados vem sendo alvo de muitas pesquisas, permitindo que os novos materiais de moldagem desenvolvidos apresentem características cada vez mais precisas. PINTO et al. ${ }^{122}$, em 1993, avaliaram a melhora na adaptação da infra estrutura pela confecção de um alívio no molde da primeira moldagem, em moldagens com silicona de adição, utilizando a técnica da dupla moldagem. Moldes com a silicona de adição Provil, na consistência leve e pesada, foram obtidos a partir de um troquel metálico padrão. A manipulação e dosagem dos materiais seguiram as orientações do fabricante. Realizaram um total de 30 moldagens, divididos em 3 grupos de 10, sendo que o $1^{\mathrm{o}}$ grupo, colocaram um casquete metálico, para proporcionar um alívio uniforme de $1 \mathrm{~mm}$ de espessura durante a primeira moldagem, com o material pesado, no segundo grupo, o alívio após a primeira moldagem foi realizado com um broca, e o terceiro grupo nenhum alívio foi executado. Após a segunda moldagem, com o material leve, os moldes foram vazados com gesso Vel-Mix. Sobre os modelos executaram o enceramento e as coroas foram fundidas. Depois da adaptação nos respectivos troquéis de gesso, as infra estruturas foram levadas ao troquel-padrão para a realização das leituras em um microscópio comparador. Os autores concluíram que o desajuste cervical das infra-estruturas foi menor quando se usou o alívio do que as que não sofreram alívio e que não houve diferença estatisticamente significante entre as duas técnicas de alívio. 
Para ROBINSON et al. ${ }^{129}$, 1994, os materiais de moldagem à base de polivinilsiloxanos são largamente empregados na odontologia restauradora, sendo que suas maiores vantagens consiste na boa estabilidade dimensional, na sua variabilidade de classes de viscosidade, para as diversas situações clínicas, na facilidade de esterilização, pela imersão em desinfetantes e o fácil manuseio. As suas dificuldades estão em controlar o tempo de trabalho e a alta tensão superficial. Os autores fizeram um estudo in vitro, na tentativa de reduzir as variáveis, associadas a moldagens registradas em pacientes, com condições de preparos orais diferentes. Foram feitas moldagens de um manequim, por estudantes de graduação, usando o sistema de automistura, de um molar inferior, preparado para receber um onlay e de um segundo molar preparado para receber uma coroa total. As moldagens foram feitas pelo emprego de moldeiras individuais, em resina acrílica, com o material Elite. Estas foram divididas em dois grupos, um empregou o sulfactante Hydrosystem, antes do vazamento dos moldes e, o outro, foi o grupo controle. Dois examinadores, treinados em uma técnica padronizada, contaram os números de bolhas visíveis, somente as dos dente preparados, nos moldes. Foram vazados dois troquéis de gesso, para cada molde satisfatório, com um gesso tipo III, manipulados à vácuo e sobre vibração. No grupo controle, o agente de umedecimento empregado foi o Wax-Mate, utilizado normalmente nos laboratórios. Os autores concluíram que o Hydrosystem reduziu significantemente o número de bolhas, nos polivinilsiloxanos e nos troquéis de gesso.

Afastamento da gengiva livre, antes da moldagem de um dente preparado, cuja linha do término cervical está apicalmente, deve ser feito para executar a moldagem. Os autores têm observados um rápido fechamento da área da linha de ângulo do sulco, para menos de 0,2 mm, após 40 segundos. O tempo de polimerização inicial, para as siliconas e poliéteres, é de 2 a 4 minutos. Alguns materiais de moldagem podem ser deslocados dos sulcos, quando o tecido retorna à posição original. Isto pode resultar em uma moldagem muito fina que pode ser quebrada ou distorcida, quando na remoção da moldagem da boca. LAUFER et al. ${ }^{89}$, em 1994, estudaram o efeito da 
variação simulado da largura do sulco, a espessura da moldagem marginal resultante, na perfeição da moldagem e a precisão dimensional linear da moldagem e do troquel de gesso. Em um bloco de metal construiu-se uma cavidade retangular no centro e seis troquéis metálico foram confeccionados para serem assentados, precisamente, nesta cavidade. Um espaço de $1 \mathrm{~mm}$, variando na largura $(0.08,0.13,0.18,0.22,0.33$ e 0.43 $\mathrm{mm}$ ), foi criado entre o troquel e a parede da cavidade. Moldeiras individuais de resina acrílica foram confeccionadas e os troquéis foram moldados, com a silicona densa Elite. As moldeiras eram perfuradas e o adesivo foi aplicado em suas paredes internas, antes da moldagem e deixadas para secar por 10 minutos. A moldeira foi carregada com a silicona densa, assentada no troquel sem pressão e deixada polimerizar sem carga, à temperatura ambiente de $23 \pm 1^{\circ} \mathrm{C}$, por 10 minutos. A extensão da moldagem, dentro do sulco, foi medida por microscopia em seis pontos. Uma hora após a polimerização, as moldagens foram vazadas com gesso extra-duro Silky, manipulado à vácuo e vibrado por 1 minuto. Assim, os moldes foram vazados e deixados por 1 hora para a presa, antes da separação. Os troquéis de gesso foram medidos de modo similar aos moldes. Os autores concluíram que a distorção existente foi significantemente maior no grupo em que o sulco era de $0.08 \mathrm{~mm}$, quando comparado aos demais grupos. Moldagens, livres de defeitos, foram obtidas, quando a largura do sulco foi de $0.18 \mathrm{~mm}$ e maior.

HONDRUM $^{77}$, em 1994, relatou que um material de moldagem deveria ter resistência suficiente para permitir a remoção do sulco gengival sem se romper, assim como adequada recuperação elástica. Para observar essas propriedades realizou estudo para determinar e comparar a resistência ao rompimento e a deformação permanente de elastômeros, envolvendo um polissulfeto, uma silicona de adição e um poliéter. O polissulfeto apresentou maior resistência ao rasgamento do que o poliéter ou silicona de adição, entretanto, esse aspecto não foi observado com a deformação permanente dos referidos materiais, sendo que o polissulfeto apresentou, em função do teste de tração, deformação muito maior (21,0 milímetros) após o teste de rompimento, do que o poliéter ( 4,15 milímetros) e silicona de adição $(0,39)$. Salientou que na remoção da 
moldagem o material sob tensão tenderia a deslocar em extensão na porção cervical. A distorção nesta direção induziria ao fechamento das margens de uma coroa total fundida ao invés de abri-las. Finaliza comentando que, quando a extensão por tração dos espécimes era menor do que 2 milímetros, a deformação permanente para todos os três materiais avaliados mostrou-se similar. Sob o ponto de vista clínico, isto justificaria o sucesso dos polissulfetos pelos profissionais, a despeito das desvantagens mecânicas enfatizadas neste estudo.

Objetivando reproduzir fielmente uma região a ser restaurada, ocasião na qual o resultado final é influenciado por inúmeros fatores, os pesquisadores têm como meta e desafio constante tanto a busca de novos materiais elastoméricos, como o aperfeiçoamento das técnicas de moldagem. Qualquer que seja o elastômero eleito, os dois métodos mais utilizados pelos pesquisadores, para avaliar seu desempenho, consistem em se medir as dimensões do seu respectivo troquel de gesso ou em se verificar a adaptação, ao troquel, de peças padronizadas, obtidas por fundição ou que as simulem, comparando tais resultados aos obtidos com a estrutura moldada. MARCHESE $^{97}$, 1994, avaliou se entre destes métodos há um mais adequado ou se ambos apresentam adequação suficiente e igual. Neste trabalho, os autores empregaram duas siliconas de adição (Provil-H e Baysilex) e uma mercaptana (Permlastic-regular). Um dispositivo de moldagem foi empregado para padronizar os moldes e consequentemente os modelos em gesso Vel-Mix. Os materiais foram sempre dosados e manipulados de acordo com as orientações dos fabricantes, sendo os moldes confeccionados em temperatura de $23 \pm 1^{\circ} \mathrm{C}$ e umidade relativa de $50 \pm 5 \%$ e sua presa na temperatura descrita ou à $37^{\circ} \mathrm{C}$. Os autores utilizaram dois tipos de medição, uma do perfil do troquel, que consistia em medir três diâmetros (oclusal, média e cervical) do troquel em um microscópio comparador, e a adaptação de uma coroa-padrão aos troquéis de gesso que foi realizada em um microscópio de profundidade. Os autor concluiu que; 1) o método de medição direta das dimensões dos diâmetros dos troquéis de gesso é inadequado para avaliar a fidelidade dos mesmos; 2) estatisticamente, 
Baysilex e Provil-H permitiram a obtenção de troquéis significantemente mais fiéis que o Permlastic-regular; 3) a temperatura de $37^{\circ} \mathrm{C}$ conduziu a piores resultados, com significância estatística, do que a de $23 \pm 1^{\circ}$.

A convivência diária com profissão odontológica, nos faz críticos a ponto de cada vez mais procurarmos a realização através de trabalhos satisfatórios. No área de prótese, a região de maior interesse é a interface restauração estrutura dentária, seguida da estabilidade dimensional dos materiais de moldagem. Pesquisadores e fabricantes tem se empenhado na obtenção de aumento de qualidade, agilidade na utilização das técnicas e compatibilidade de preço com o mercado. Em 1995, ARAÚJO et al. ${ }^{11}$, verificaram a influência do reaquecimento de mercaptanas e siliconas de adição nos moldes de gesso para prótese fixa. Para esta pesquisa foi desenvolvido um dispositivo composto de dois cones truncado separados por uma distância semelhante à um pôntico, simulando uma prótese parcial fixa. Os materiais de moldagem (Provil L, Baysilex - siliconas de adição e a mercaptana Permlastic-regular) foram dosados e manipulados de acordo com as orientações dos fabricantes, em uma temperatura ambiente de $22 \pm 2^{\circ} \mathrm{C}$. Imediatamente após a moldagem o dispositivo era transferido para um recipiente contendo água a $37^{\circ} \mathrm{C}$, onde permanecia por 15 minutos, para a polimerização do material, momento em que o conjunto era removido do recipiente e o molde separado e deixado descansar a $22 \pm 2^{\circ} \mathrm{C}$, por um período de 30 minutos, e então os moldes eram vazados em gesso Vel-Mix. As coroas padrões foram então posicionadas sobre os modelos de gesso e medida a sua adaptação em um microscópio de profundidade. Os autores concluíram que os valores obtidos não se pode afirmar que os modelos provenientes de moldes reaquecidos, apresentaram maior precisão do que os $22 \pm 2^{\circ} \mathrm{C}$; o material de moldagem que apresentou o melhor resultado foi a silicona de adição Baysilex.

A confecção de algumas próteses requerem moldagens precisa dimensionalmente. $\mathrm{O}$ emprego de moldeiras individuais para melhorar a precisão dos 
moldes subseqüentemente das próteses tem sido avaliadas por diversos estudos. Por conseguinte uma melhor uniformidade na espessura do material de moldagem pode ser conseguida com o auxílio de moldeira individual, o que melhora a precisão. PAYNE; PEREIRA $^{117}$, em 1995, compararam a força de adesão de dois materiais de moldagem elastoméricos, bem como a influência da rugosidade dos materiais de resina, para confecção de moldeiras individuais, têm nesta adesão. Os materiais utilizados foi o Hidrosyl e o Permadyne e os seus respectivos adesivos e as resinas para moldeiras Hydrotray, Tray Dough. Foi desenvolvido um dispositivo para o teste que fixava-se à máquina de teste de tensão. As moldeiras foram confeccionadas sobre um modelo de gesso e empregou-se uma broca carbide para promover rugosidades, as quais deveriam ser visíveis. Uma camada de adesivo foi aplicado sobre as moldeiras e deixado secar por 15 minutos, os elastômeros foram dosados e manipulados de acordo com as recomendações dos fabricantes, a moldeira foi carregada com a mistura e o dispositivo foi mantido fixo, por pressão manual, proporcionando uma espessura uniforme do material de moldagem de $3 \mathrm{~mm}$. A área de contato entre o elastômero e a resina foi de $380 \times 10^{-6} \mathrm{~mm}^{2}$. Os corpos de prova foram testado em uma máquina de teste universal, e análise estatística de variância (ANOVA) foi aplicada. Os autores concluíram que o Hydrosil e o Permadyne mostraram uma maior união à moldeira de Hydrotray do que à da Hygenic; a rugosidade na superfície na resina Hydrotray resultou em uma redução significativa na união da silicona de adição monofásica (Hydrosil), mas aumentou a união com o Permadyne e ambos não mostraram diferenças de união, quando o material da moldeira empregado foi o Hygenic, e todos os corpos de prova apresentaram significativamente menor união com este material.

BOULTON et al. ${ }^{30 .}$, em 1996, salientaram que o sucesso clínico de uma prótese fixa está, em parte, na dependência da precisão dimensional dos materiais de moldagem. Para tanto avaliaram a precisão vertical e horizontal de moldagens realizadas com silicona de adição ( técnica da dupla mistura e reembasamento pesado/leve), poliéter e polissulfeto utilizando tanto moldeira individual como de 
estoque. Modelo padrão de aço inoxidável composto de preparos tipo coroa total, com dimensões representativas de pré-molares e molares e medidas pré-estabelecidas, foi utilizado. Moldeiras individuais de acrílico que proporcionavam aproximadamente 3,5 milímetros para o material de moldagem e moldeiras de estoque ( arcada inferior) com perfurações foram empregadas para os diferentes materiais. Para realização das moldagens seguiram as instruções dos respectivos fabricantes, vazando gesso tipo IV uma hora após a obtenção dos moldes. A precisão das moldagens foi determinada nos troquéis de gesso obtidos, comparando as dimensões horizontais, verticais e entre os preparos do modelo padrão e dos troquéis de gesso, sendo que cada réplica foi medida três vezes consecutivas em 16 pontos. Os resultados mostraram que o polissulfeto (Permlastic) foi o material menos preciso nas análises das dimensões vertical e horizontal, entretanto, não foi observada diferença estatisticamente significante quando se analisou a distância horizontal entre os preparos. Destacaram que os troquéis obtidos com moldes de polissulfeto mostraram dimensões diminuídas no sentido vertical, ou seja, mais curtos, tanto para moldagens com moldeiras individual como de estoque. Concluíram que aqueles com moldeiras de estoque produziam resultados imprecisos na dimensão entre preparos e que clinicamente parecem ser aceitáveis para elementos isolados, devendo-se evitar o uso de polissulfeto para moldagem. Entretanto, para preparos para próteses fixas, a moldeira individual seria mais apropriada para moldagem com todos os materiais.

Vários tipos de materiais de moldagem são usados na confecção de prótese fixa, para a reprodução de dentes e estruturas correlatas. Produção de coroas e fixas excepcionais requerem o emprego de materiais de moldagem que reproduzam com fidelidade os dentes preparados e as estrutura vizinhas. Uma aceitação comum entre os dentistas é que o material de moldagem satisfaça os padrões da A. D. A., no que diz respeito à habilidade precisa de reprodução de detalhes. Embora os testes empregados forneça uma boa base de dados para a comparação dos materiais, as condições dos testes diferem das condições clínicas. Em 1997, FEDERICK; CAPUTO ${ }^{65}$, avaliaram a 
precisão de hidrocolóide reversível, polivinilsiloxano e o poliéter usados em conjunto com dois tipos de gesso. Os autores fabricaram um modelo padrão do arco superior, em resina acrílica autopolimerizável, com todos os dentes, exceção feita a um espaço desdentado posterior, no qual os dentes contíguos foram preparados para receber uma coroa total, e o primeiro molar do lado oposto recebeu um preparo para receber uma onlay. Linhas foram delineadas nos dentes para servirem de referências para posterior medição de comparação. Os materiais foram dosados e manipulados de acordo com as orientações dos fabricantes, com exceção do poliéter que o seu tempo de mistura foi aumentado em $25 \%$ para que a mistura ficasse homogênea. As moldeiras de plástico perfuradas, usualmente empregadas nos consultórios, foram carregadas com o material de moldagem e moldagens foram feitas do modelo padrão, os moldes foram então vazados com gesso tipo IV. Para comparar a precisão dos materiais de moldagem foram feitas comparações entre as dimensões do modelo padrão e os modelos de gesso. Concluíram que a precisão dos modelos foi independente dos gessos testados para todos os materiais de moldagem testado; os dois polivinilsiloxano não foram equivalente em precisão; os dois hidrocolóide reversível produziram modelos equivalentes e dos materiais testados o hidrocolóide e poliéter foram os mais precisos.

A adesão do material de moldagem à moldeira é um fator importante que pode afetar a precisão das restaurações fundidas. GRANT; TJAN ${ }^{68}$, em 1998, analisaram a resistência à tensão e a união da película adesiva de vários materiais de moldagem. Os elastômeros e os respectivos adesivos empregados foram os polissulfetos (Coeflex e Permlastic), as siliconas de condensação (Ovation e Xantopren), os poliéteres (Impregum F e Permagum) e as siliconas de adição (Reprosil, Exaflex e Permadyne). Os autores empregaram blocos de resina acrílica para o teste, sendo cada superfície destes blocos brunidas para torna-las uniformes, duas camadas de adesivos foram aplicadas, de acordo com as orientações dos fabricantes, deixados no meio ambiente para secagem por um período de 15 minutos antes da aplicação do material de moldagem. Os elastômeros foram dosados e manipulados de acordo com os 
fabricantes, colocados na superfície dos blocos que tinham sido cobertas pelo respectivo adesivo e os blocos foram prensados para que mantivessem uma espessura uniforme de material de $3 \mathrm{~mm}$. Os materiais foram deixados na temperatura ambiente por um período de 30 minutos para a sua polimerização, antes de irem para a máquina de teste universal Riehle. Concluíram que a resistência à tração dos adesivos foram maiores do que a união da película, exceto para o Permadyne e Exaflex e para o Permagum que exibiu o mesmo resultado; as siliconas polimerizadas por reação de condensação apresentaram menor resistência em ambos os testes.

Estudos anteriores tem mostrados um relação entre o processo de desinfecção, umedecimento e a mudanças na massa dos materiais de moldagens. Materiais de moldagem de baixa viscosidade manualmente manipuláveis geralmente resultam em um material com um maior número de bolhas, que contribuem para uma superfície mais rugosa e afetam as características superficiais dos materiais. LEPE et al. ${ }^{90}$, em 1998, estudaram o efeito da técnica de mistura nas propriedades de umedecimento de nove elastômeros sem a desinfecção dos moldes, e após imersão em desifectantes depois de 1 e 18 horas em solução de ácido glutaraldeído a $2 \%$. Embebição após a desinfecção associada à perda de massa por evaporação das amostra através do peso. A técnica de Wilhelmy foi empregada para determinar as propriedades de umedecimento dos materiais testados, que eram o Impregum (F e Penta), Pemadyne (Seringa), Garant e Penta, Dimension (Penta e Garant L) e Aquasil. Os corpos de prova possuíam a forma de um cilindro, e as condições incluíam nenhuma desinfecção ou desinfeção por imersão em uma solução de ácido glutaraldeído (Banicide) a 2\% por um período de 1, 5 e 18 horas. Os corpos de prova eram ainda pesados antes e após a imersão a fim de detectar a perda ou ganho de massa. A perda de massa no meio ambiente também foi avaliada. Os resultados foram avaliados por analise de variância. Os autores concluíram que os poliéteres possuem um maior umedecimento do que as siliconas de adição. A embebição foi afetada após os materiais terem passados pelo processo de desinfeção após 1 e 18 horas. 
A moldagem das estruturas bucais, que expõem claramente a linha de término do preparo, é essencial para a precisão das restaurações de próteses fixas. Consiste numa série de procedimentos interdependentes somados a materiais variados e representa um dos momentos mais críticos da clínica na tentativa de obter réplicas dos preparos realizados. SPYRIDES et al. ${ }^{140}$, em 1998, apresentaram um técnica simples, segura e alternativa de moldagem com casquetes de acrílico obtidos através da coroa provisória. O resultado final é uma moldagem para um ou vários preparos coronários, com acrílico-elastômero-alginato de todo o arco que incorpora uma moldagem de precisão, de cada dente preparado com afastamento gengival descomplicado e atraumático.

As siliconas de adição são materiais considerados precisos, dimensionalmente estáveis, e relativamente fáceis de serem usados na odontologia restauradora. As siliconas polimerizadas por adição monofásicas em moldeiras de estoque são consideradas como um meio alternativo ao sistema de dupla fase usadas com moldeiras individuais. Em 1998, MILLAR et al. ${ }^{108}$ Compararam o número de defeitos superficiais registrados na moldagem com silicona de adição mono-fase e moldeira de estoque e de duas fases em moldeira individual. O número de bolha, visíveis, existentes nos moldes das siliconas mono-fase (President Monobody System e Bayer Cutter)) e da de duas fases (Presidente Plus e Zermack Elite) foram contadas, em um total de 200 moldes, sendo 50 para cada material. Os moldes foram examinados nas bolhas superficiais existentes em uma parte preparada de um dente por um examinador experiente. Os autores concluíram que a silicona monofásica apresentou uma diminuição na formação de bolhas superficiais quando comparada com a silicona de duas fases. 
3 - Proposição 


\section{3 - Proposição}

Com apoio nos argumentos até aqui apresentados, ficou estabelecido que o objetivo do presente trabalho será avaliar a fidelidade morfodimensional de troquéis de um gesso tipo IV, através do uso de um dispositivo constituído de uma coroa metálica usinada que se adapta com alta precisão em um troquel-padrão metálico original que, simula um dente preparado para receber um coroa total; os troquéis serão confeccionados a partir de moldes obtidos com cinco elastômeros (Express e President, Impregum F, Imprint e Permlastic) e se pretende avaliar a fidelidade dos troquéis de gesso, quando obtidos:

3.1 - por uma técnica de dupla moldagem com dois dos elastômeros, em duas espessuras de alívios (1 e $2 \mathrm{~mm}$ );

3.2 - pela técnica do casquete utilizando-se todos os cinco elastômeros, em uma única espeesura de alívio $(0,2 \mathrm{~mm})$. 
4 - Materiais e método 


\section{4 - Materiais e método}

\section{1 - Ajuste do dispositivo de moldagem}

Os materiais de moldagem utilizados para o desenvolvimento desta pesquisa foram os elastômeros listados no quadro 1 . O único material de modelo usado nesta pesquisa foi o gesso Vel-Mix (tipo IV), fabricado por Kerr Manufacturing Company, Romulus - MI - EUA, lote n ${ }^{0}$ 7-21316.

Quadro 4.1- Elastômeros utilizados e algumas de suas características.

\begin{tabular}{|c|c|c|c|}
\hline Marca & Fabricante & Tipo & Lote \\
\hline Express & $3 \mathrm{M}$ & Silicona de adição & $\begin{array}{c}\text { 19951-120 seringa (fluido) } \\
19951-205 \text { (massa) }\end{array}$ \\
\hline Impregum F & Espe & Poliéter & 049 \\
\hline Imprint & $3 \mathrm{M}$ & Silicona de adição & 9425-H seringa (fluido) \\
\hline Permlastic & Kerr Man. Comp. & Polissulfeto & $6-1229$ (base) \\
& Romulus - MI - EUA & & 6-1235 (cat.) \\
\hline President & Coltène & Silicona de adição & EC-932 (fluido) \\
& & & EK-446 (massa) \\
\hline
\end{tabular}

Para a realização deste estudo, empregou-se um dispositivo de moldagem, idealizado em 1985 por ARAÚJO; JÖRGENSEN ${ }^{6}$ e esquematizado na figura 4.1, o qual possui duas plataformas, uma inferior, também denominada base (B), onde é fixada a moldeira (M), e outra superior, chamada parte móvel do dispositivo (PM), na qual é preso o troquel metálico (T), usado como padrão, que é fixado à parte móvel por intermédio do parafuso fixador do troquel (PFT), que inclusive transfixa o cilindro auxiliar de fixação do troquel (CAFT). A plataforma superior, na extremidade oposta àquela em que é fixado o troquel, possui um anel que pode ser encaixado numa haste cilíndrica vertical (HV); esta última é fixada à base, na extremidade oposta àquela onde pode ser ajustada e fixada a moldeira, pelo parafuso fixador da moldeira (PFM). A citada haste, longitudinalmente, apresenta um rasgo em toda sua extensão, onde se encaixa um dente interno do anel da plataforma superior. Deste dispositivo ainda fazem 
parte, um anel de manutenção da altura da parte móvel (AMA), um anel espaçador (AE) e um cilindro centralizador (CC), cujas funções serão posteriormente descritas.

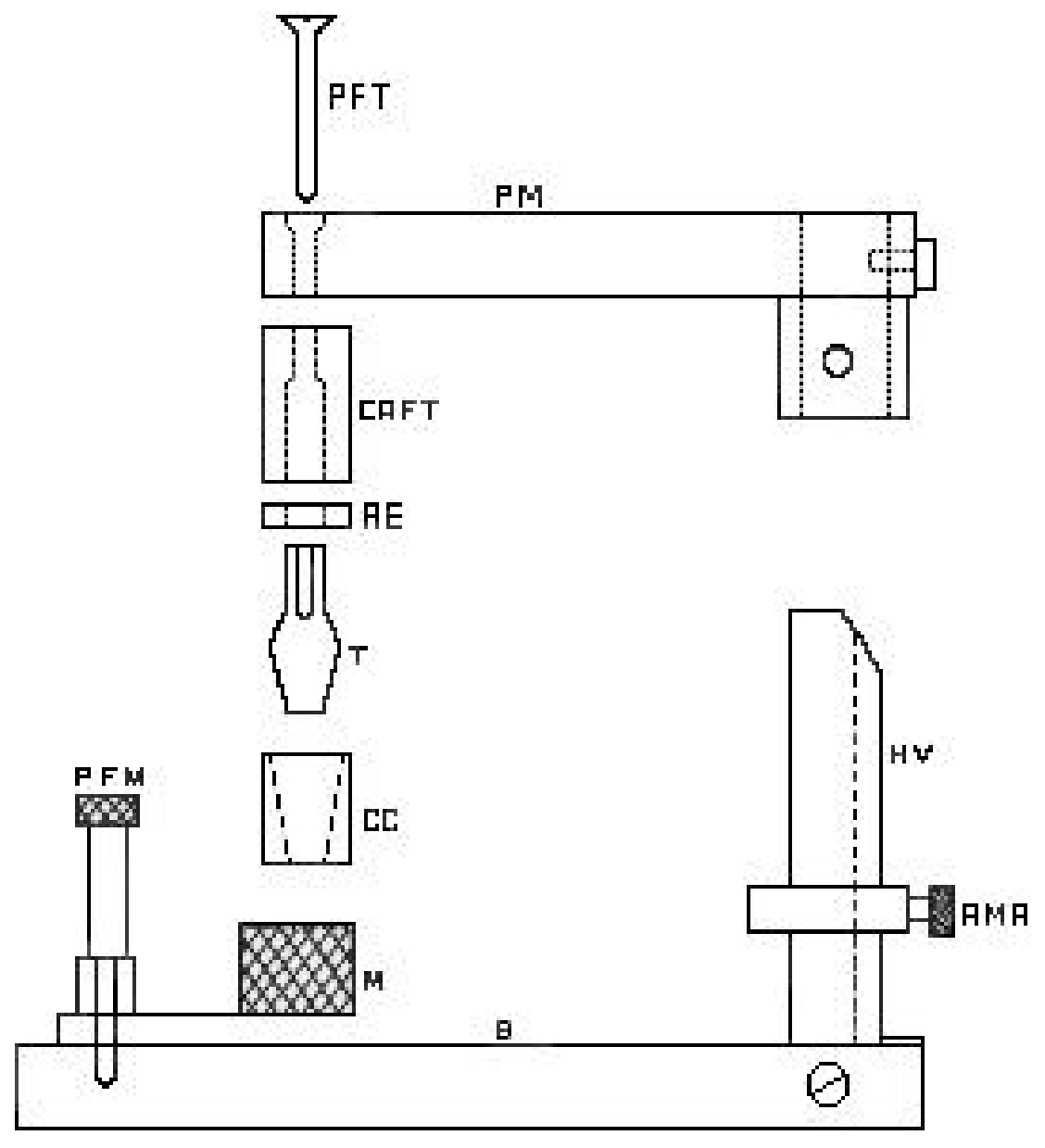

Figura 4.1 - Esquema do dispositivo de moldagem: B - base; M - moldeira perfurada; PM - parte móvel; T - troquel-padrão metálico; PFT - parafuso fixador do troquel; CAFT - cilindro auxiliar de fixação do troquel; HV - haste vertical da base; PF .parafuso fixador da moldeira; AMA - anel de manutenção da altura da parte móvel; AE - anel espaçador; CC - cilindro centralizador (original de ARAÚJO; JÖRGENSEN ${ }^{6}$ ).

O troquel-padrão, torneado em aço inoxidável e cujo esquema pode ser observado na figura 4.2, simula um dente preparado para receber uma coroa total. Sua porção principal tem a forma de um tronco de cone e, na porção cervical, após o final do preparo, apresenta uma região retentiva que se une à um "pescoço" cilíndrico. 


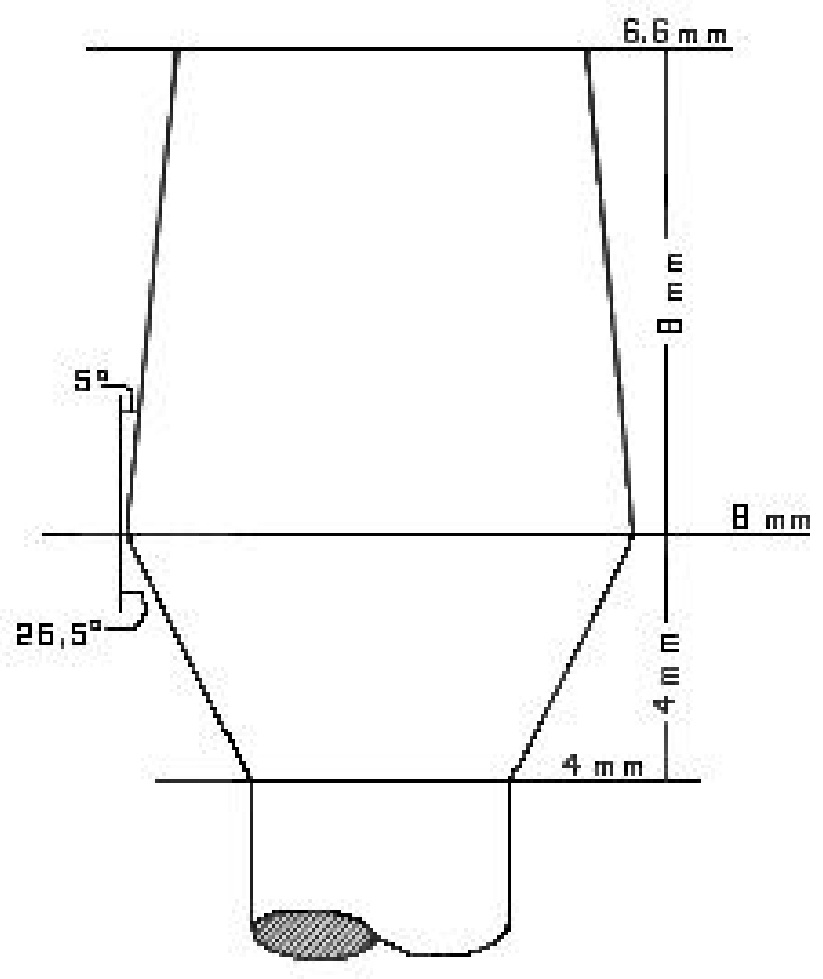

Figura 4.2 - Esquema do troquel-padrão referido no texto, com todas as dimensões expressas em mm.

As dimensões de futuros troquéis de gesso seriam comparadas às do troquel-padrão, através de um anel de medição (também denominado coroa-padrão), igualmente confeccionado em aço inoxidável, cuja luz tronco-cônica apresenta dimensões tais que ele se encaixa com justeza no troquel-padrão, o que significa que se este troquel-padrão estiver com a face oclusal voltada para cima, o plano desta sua face encontra-se na mesma altura das bordas "oclusais" do anel de medição, desde que exista uma padronização do posicionamento deste anel no troquel-padrão. $\mathrm{Na}$ face oclusal do citado troquel, próxima à borda, existe uma marca (depressão puntiforme) chamada convencionalmente como de 12 horas. Também na borda do anel de medição, existem outras marcas: a região das 12 horas é caracterizada por uma dupla de depressões próximas; outras três marcas semelhantes, todas elas unitárias, respectivamente caracterizam as posições de 3, 6 e 9 horas. Considera-se adequadamente posicionado o 
anel de medição no troquel-padrão, quando a depressão mais externa do conjunto das 12 horas, existente na borda do primeiro, estiver alinhada com a marca do troquelpadrão e com o centro imaginário de sua face oclusal, como ilustrado pela figura 4.3.

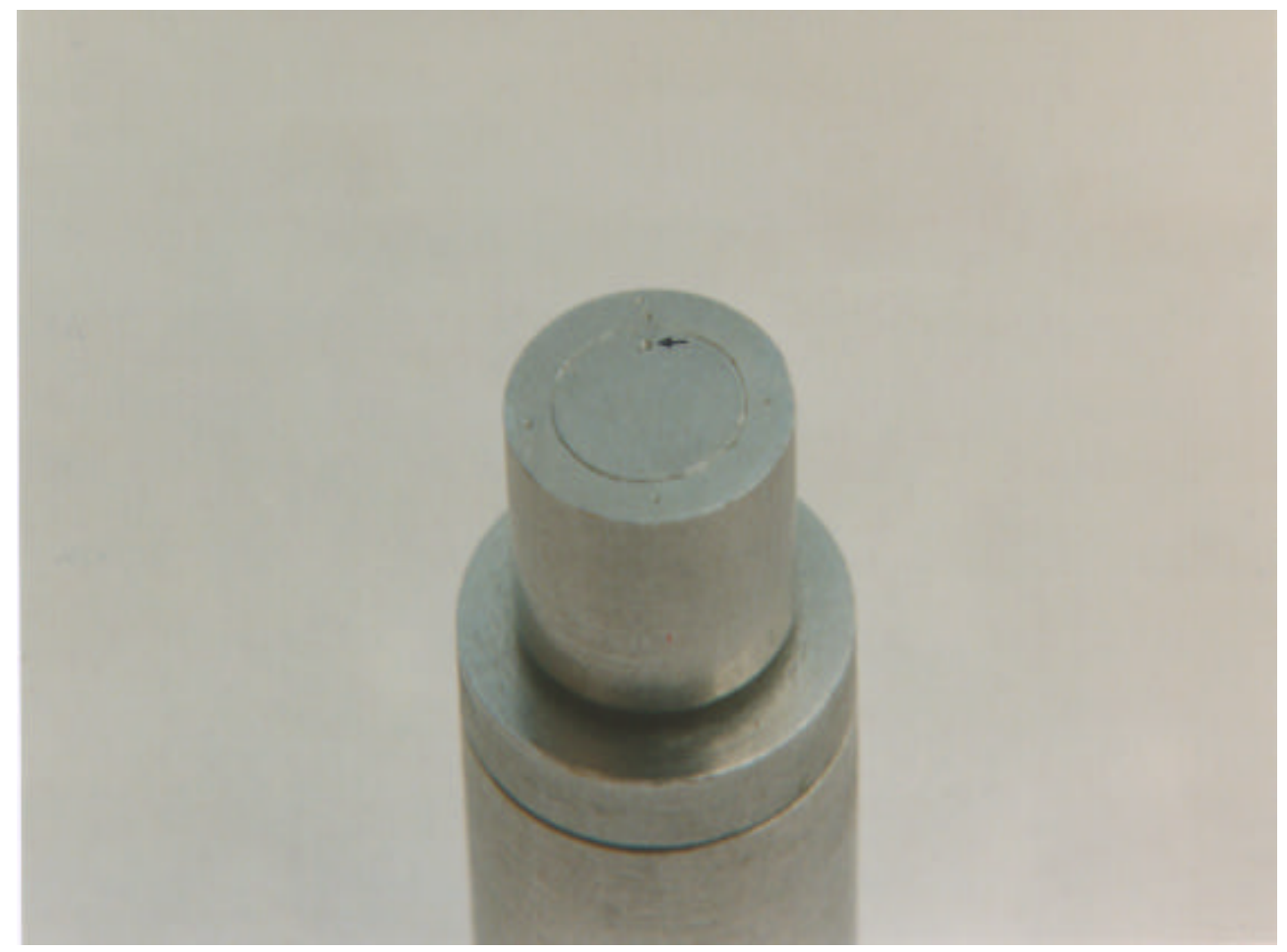

Figura 4.3 - Fotografia do troquel-padrão metálico, visto principalmente por oclusal (com o ponto em depressão indicado pela seta ), e da coroa-padrão em posição adequada, como descrito no texto.

No trabalho original de ARAÚJO; JÖRGENSEN ${ }^{6}$, existem 3 anéis espaçadores, de espessuras diferentes, cuja função é fazer variar a área retentiva abaixo da porção cervical do troquel-padrão. Para o presente trabalho, foi escolhido o anel espaçador de $3 \mathrm{~mm}$ de espessura, o qual foi fixado no troquel-padrão (assim proporcionando uma retenção de $1 \mathrm{~mm}$ de altura, verticalmente), o qual por sua vez foi fixado na parte móvel do citado dispositivo de moldagem.

Foram analisadas duas diferentes técnicas de moldagem: a de dupla moldagem (utilizando-se a massa e a pasta dos elastômeros das marcas Express e 
President) e a por casquete (usando-se apenas as pastas dos elastômeros já citados e ainda os produtos Permlastic, Imprint e Impregum F).

Quando era executada a técnica da dupla moldagem, o ajuste do dispositivo de moldagem era feito da seguinte maneira: o cilindro centralizador era adaptado no troquel-padrão e o anel da plataforma superior era então encaixado na haste vertical da base e deslizado para baixo, até que o citado cilindro se ajustasse à moldeira; esta se encontrava solta e provisoriamente posicionada na base, até que a posição definitiva fosse encontrada; isto acontecia quando o anel centralizador tocava o fundo da moldeira, ocasião em que a mesma era fixada à base, através do parafuso que a imobilizava, visto prender duas hastes que nela existiam, soldadas à sua base.

$\mathrm{O}$ anel de manutenção de altura (identificado pela sigla AMA, na figura 4.1), que já se encontrava encaixado à citada haste vertical, era então elevado até tocar no anel da plataforma superior, onde era fixado por um parafuso, enquanto as plataformas eram manualmente mantidas imóveis. A visão do conjunto, neste momento, após uma pequena elevação da plataforma superior, é ilustrada pela figura 4.4, onde pode-se observar o cilindro centralizador (confeccionado em bronze) no interior da moldeira já imobilizada. 


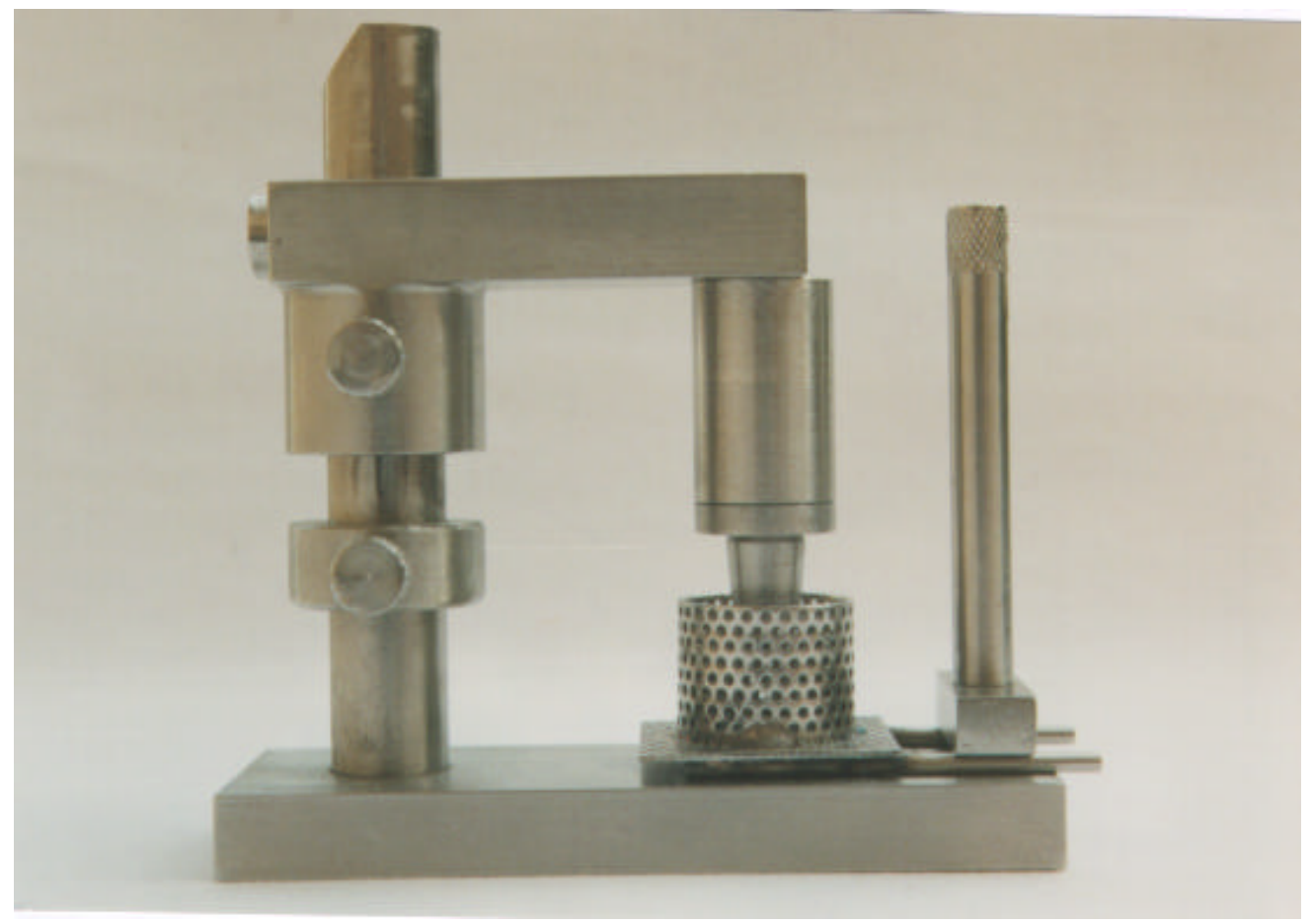

Figura 4.4 - Fotografia do dispositivo de moldagem, após a fixação definitiva da moldeira em posição e do anel de manutenção de altura da parte móvel.

Quando da realização dos ensaios pela técnica do casquete, o ajuste do dispositivo de moldagem era feito com o auxílio de um primeiro casquete (centralizador) anteriormente confeccionado em resina acrílica (Duralay*), com espessura tal que, quando adaptado ao troquel-padrão (sobre o qual fora construído), funcionava como o já citado cilindro centralizador. $\mathrm{O}$ anel da plataforma superior era então encaixado na haste vertical da base e deslizado para baixo, até que o citado casquete se ajustasse a um segundo (o de moldagem, também confeccionado com o mesmo material do primeiro), que se encontrava fixado com resina acrílica à um dispositivo semelhante à parte basal da moldeira usada para a técnica anteriormente descrita; este encontrava-se solto e provisoriamente posicionado na base "B" do conjunto de moldagem, até que a posição definitiva fosse encontrada, o que acontecia quando o primeiro casquete tocava o fundo do segundo; nesta ocasião, o dispositivo era fixado à base do conjunto de modo semelhante ao já descrito para a técnica da dupla moldagem; também de modo semelhante, o anel de manutenção de altura era então

* Duralay Reliance Co Manufactoring 
fixado. A visão que se tinha do conjunto, naquele momento, é ilustrada na figura 4.5, onde uma pequena elevação da plataforma superior do dispositivo de moldagem permite a visão do casquete centralizador( posicionado no troquel-padrão) com o de moldagem já fixado na parte basal do seu dispositivo de suporte, com este por sua vez já fixado definitivamente na haste do conjunto de moldagem.

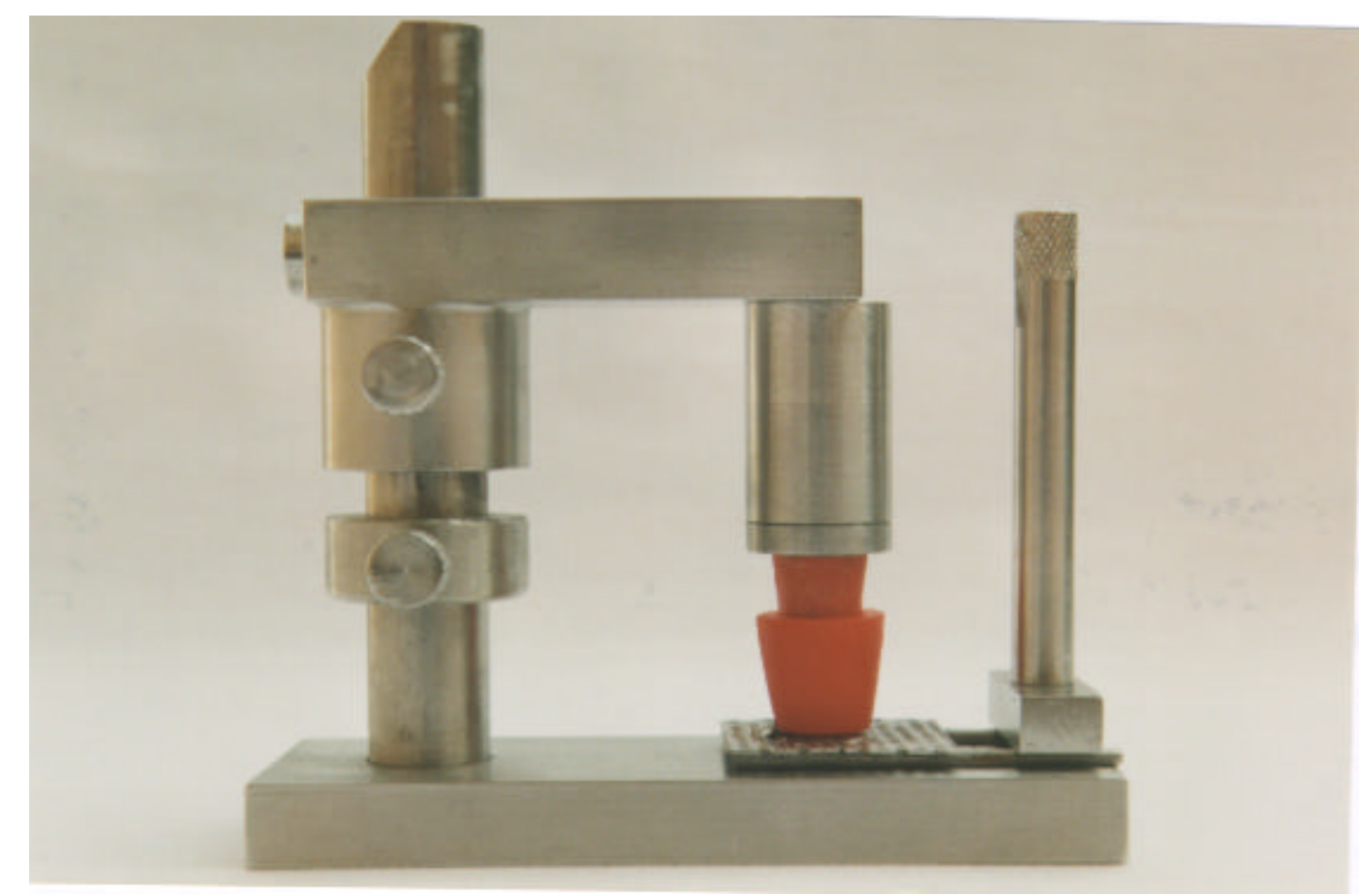

Figura 4.5 - Fotografia do conjunto de moldagem, após a fixação do casquete de moldagem em sua posição definitiva, da forma descrita no texto.

A plataforma superior era então retirada da haste cilíndrica e o primeiro casquete era removido do troquel-padrão, ao qual ficava preso, visando uma uniformização da espessura do material, durante o ato da moldagem, o cilindro centralizador (na técnica da dupla moldagem) apresentava dimensões tais que, após sua retirada, desde o troquel até as paredes laterais internas da moldeira (no nível do maior diâmetro daquele) e desde a face oclusal do troquel até o fundo da moldeira, as distâncias eram de cerca de $3 \mathrm{~mm}$; igualmente, na técnica do casquete, tais distâncias 
internas eram de $0,2 \mathrm{~mm}$, proporcionadas pela espessura igual do casquete centralizador.

Foram confeccionadas 10 moldeiras e 10 bases para fixação dos 10 casquetes, disponíveis, todas com dimensões praticamente iguais, para permitir maior rapidez na execução do trabalho. Como continente do material de moldagem, as moldeiras cilíndricas, confeccionadas em aço inoxidável, com furos em todas as paredes, apresentavam internamente $16 \mathrm{~mm}$, tanto na altura, quanto no diâmetro, enquanto os casquetes de moldagem apresentavam o alívio descrito no parágrafo anterior.

Para a uniformidade na espessura da pasta fluida, na técnica da dupla moldagem, confeccionou-se 2 casquetes, com 1 e $2 \mathrm{~mm}$ de espessura respectivamente, em resina acrílica Duralay, os quais se encaixavam com justeza na coroa-padrão e determinavam a espessura da pasta.

No caso da técnica do casquete, para o Express e o President, foi utilizada a pasta fluida; para o Imprint e o Permlastic, a de consistência regular e, para o Impregum, a de média. Para o Imprint e Impregum F, estas pastas são apresentadas apenas nas consistências referidas. 


\section{2 - Obtenção dos moldes}

Todos os procedimentos aqui descritos foram executados em ambiente com temperatura e umidade controladas, com temperatura de $23 \pm 1^{\circ} \mathrm{C}$ e umidade relativa do ar de $50 \pm 5 \%$. Como o Express e o President são apresentados também na forma de massa, ambos foram utilizados na técnica de dupla moldagem, pois ainda são acompanhados pelas pastas fluidas; adicionalmente, estas pastas foram utilizadas na técnica do casquete; já os produtos (Impregum, Imprint e o Permlastic) foram empregados apenas na técnica do casquete, justamente por não serem apresentados na forma de massa.

Os componentes de todos os materiais de moldagem sempre foram dosados de acordo com a orientação dos fabricantes; para os produtos President e Permlastic deveriam ser misturados volumes iguais das pastas base e "catalisadora"; enquanto que, para o Impregum, a proporção era de 7/1. Assim é que foram confeccionados dosadores, dois para cada produto e, destes, um para cada pasta estes consistiam de seringas hipodérmicas de "Teflon", com capacidade para $10 \mathrm{ml}$ (encontradas rotineiramente em farmácias) cujas extremidade (internamente com a forma cônica) foram cortadas (com disco comum de carborundo) no nível da marca zero, para facilitar a acomodação do material em seu interior; cada êmbolo também apresentava a extremidade cônica e, ao se posicionar a base deste cone na marca de $1 \mathrm{ml}$, conseguiase dosar sempre o mesmo volume de material, quantia suficiente para se executar cada moldagem, no caso do President e Permlastic; para o Impregum, media-se 3,5 $\mathrm{ml}$ de base e $0,5 \mathrm{ml}$ de "catalisador".

O Express (pasta fluida) e o Imprint encontravam-se embalados em seringas próprias nas quais a pasta base e "catalisadora" são misturadas, ao comprimir-se os respectivos êmbolos, quando da dispensa da quantia a ser usada; existia uma pistola onde tais seringas são adaptadas. É necessário apertar repetidamente o gatilho da

* Politetrafluoretileno; marca registrada da E. I. Du Pont de Nemours. 
pistola, até o seu bico plástico descartável ser preenchido com a mistura e possibilitar sua dispensa na quantia adequada.

Na técnica da dupla moldagem, para o President e o Express, a massa (base) e a do respectivo "catalisador" foram dosadas, e sua mistura também foi executada, conforme as recomendações do fabricantes, manualmente, com as pontas dos dedos, até que se conseguisse uma massa de textura homogênea e cor uniforme, a qual era colocada na moldeira, já fixada na base do dispositivo de moldagem; a plataforma superior era então adequadamente, encaixada na haste cilíndrica e baixada, até que tocasse no anel de manutenção de altura, que já se encontrava firmemente fixado. Como o troquel fazia parte deste sistema rígido, durante esta operação, ele era concomitante e adequadamente introduzido no interior da moldeira, momento em que se procedia à imobilização da plataforma superior, através do parafuso próprio.

Aguardava-se 10 minutos para a polimerização do material, quando a plataforma superior era separada do molde, momento em que o casquete espaçador era removido da coroa-padrão, proporcionando assim a quantia necessária de "alívio" (1 ou $2 \mathrm{~mm}$ ); o molde era então deixado repousar sobre a bancada, para liberação de tensões induzidas, por 15 minutos.

Após decorrido o tempo acima, executava-se a moldagem com a mistura fluida. No caso do material President, a pasta base e seu "catalisador" eram manipulados em um bloco de papel (fornecido pelo fabricante), com a espátula de “Teflon", durante 30 segundos, obtendo-se, ao final deste período, uma massa de textura homogênea e cor uniforme. Sabe-se que, no início da espatulação, a espátula é empunhada com seu longo eixo inclinado, quase perpendicular ao plano da folha de espatulação (“espátula de pé”), o que facilita o início da tarefa; progredindo o tempo de mistura, consegue-se sentir que a inclinação da espátula pode ser progressivamente diminuída, até a posição de "espátula deitada". isto nos momentos finais, inclusive quando suas faces são pressionadas contra o material, com a finalidade de eliminar bolhas de ar. No caso do material Express, a dosagem e a mistura do material eram feitas com o uso da pistola que acompanha o conjunto. 
Uma parte do material recém-misturada era aplicada, no caso do President com um pincel n 2 - 266 (Tigre*), inicialmente nas regiões retentivas do troquel e, depois, em todas as superfícies (circundantes e oclusal), buscando assim diminuir-se a possibilidade de oclusão de bolhas de ar, como observado anteriormente na fase de testes preliminares; nesta altura, o troquel continuava com sua face oclusal voltada para cima, fixo na plataforma superior, que repousava sobre a mesa; o molde era então carregado com o restante da massa, com o auxílio da própria espátula usada na mistura.

No caso do Express (pasta fluida) aplicava-se a mistura ao molde e ao troquel, com o bico da própria pistola.

Despendia-se (em média) um tempo de 30 segundos, desde o início da colocação do material no troquel até o momento da imobilização, nesta $2^{\mathrm{a}}$ operação de moldagem. A partir deste momento, o conjunto permanecia na condição ambiental citada. Aguardava-se a polimerização do material, até os 10 minutos, contados a partir do início da mistura (figura 4.6), quando então o molde era removido do troquel-padrão e avaliado visualmente para a detecção de eventuais bolhas, que levariam ao descarte, quando novo espécime era imediatamente confeccionado.

$\mathrm{Na}$ técnica do casquete, inicialmente, nele aplicava-se o adesivo próprio, aguardando-se sua secagem por 5 minutos, a mistura da pasta com seu respectivo “catalisador" era efetuada com uma espátula metálica n 32 , para o Impregum F e o Permlastic; para o President empregou-se a espátula de "Teflon"; para o Express e o Imprint, a mistura já ocorria na própria pistola em que eles apresentavam-se embalados. A mistura resultante, para os três primeiros produtos aqui citados, era aplicada ao troquel e ao casquete, da forma já referida na técnica anteriormente apresentada para o próprio President; para os dois últimos, esta tarefa era efetuada com a própria pistola, como também já descrito para o próprio Express, na técnica da dupla moldagem(figura 4.6). Os demais atos operacionais eram semelhantes aos já descritos, até o momento do exame visual do molde.

* Tigre do Brasil 


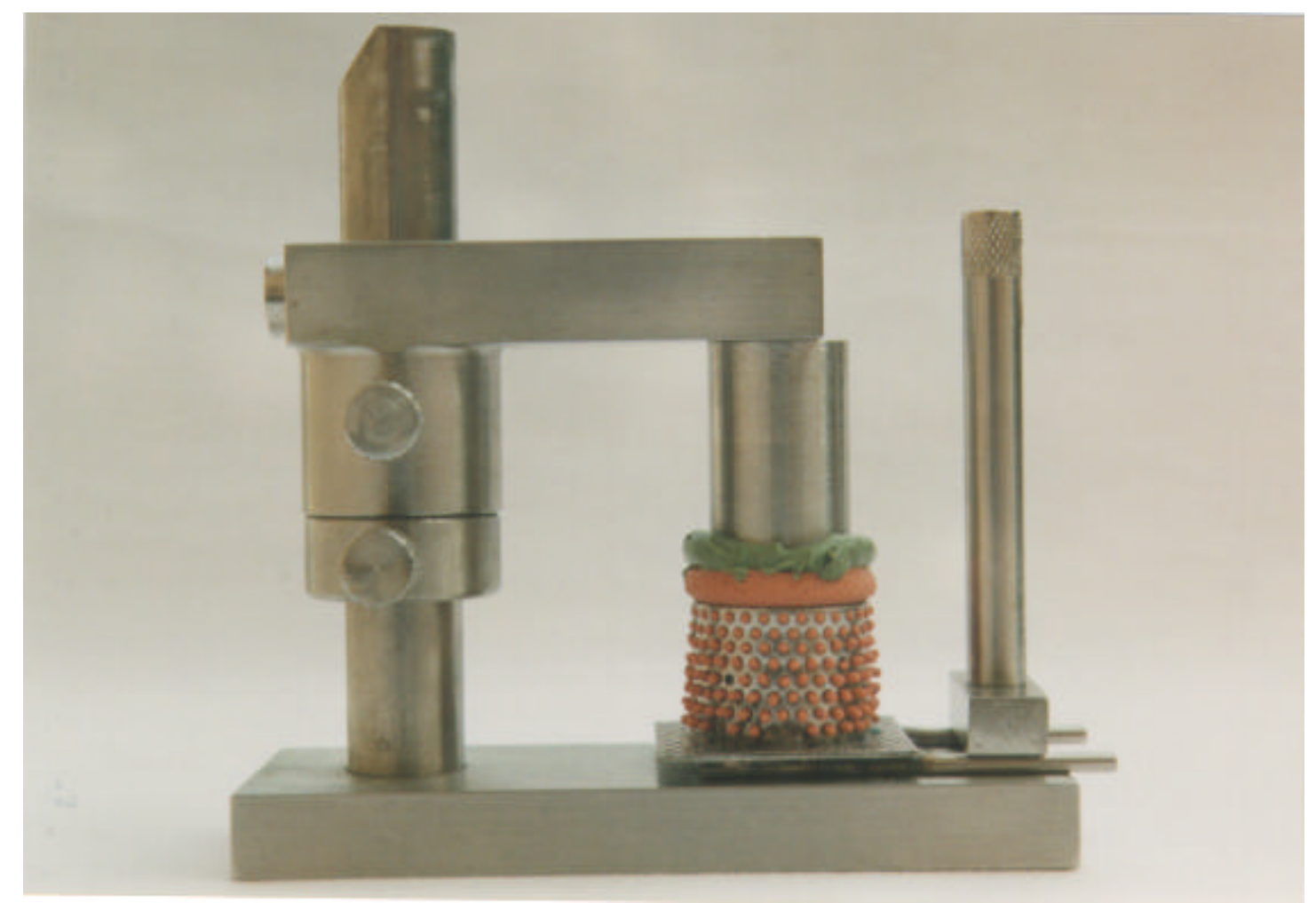

Figura 4.6 - Aspecto do conjunto de moldagem, para um caso qualquer da técnica da dupla moldagem, após a imobilização da parte móvel (PM) e antes do troquel ser removido do molde, como explicado no texto.

O molde considerado adequado era deixado "repousar" sobre a bancada, por um período adicional de 15 minutos, para liberação de tensões induzidas. Existiu, ainda, o cuidado de se confeccionar, sempre em ordem aleatória, um molde com cada um dos elastômeros, alternadamente.

Para fins ilustrativos, um molde qualquer, obtido em cada uma das técnicas, pode ser observado na figura 4.7 . 


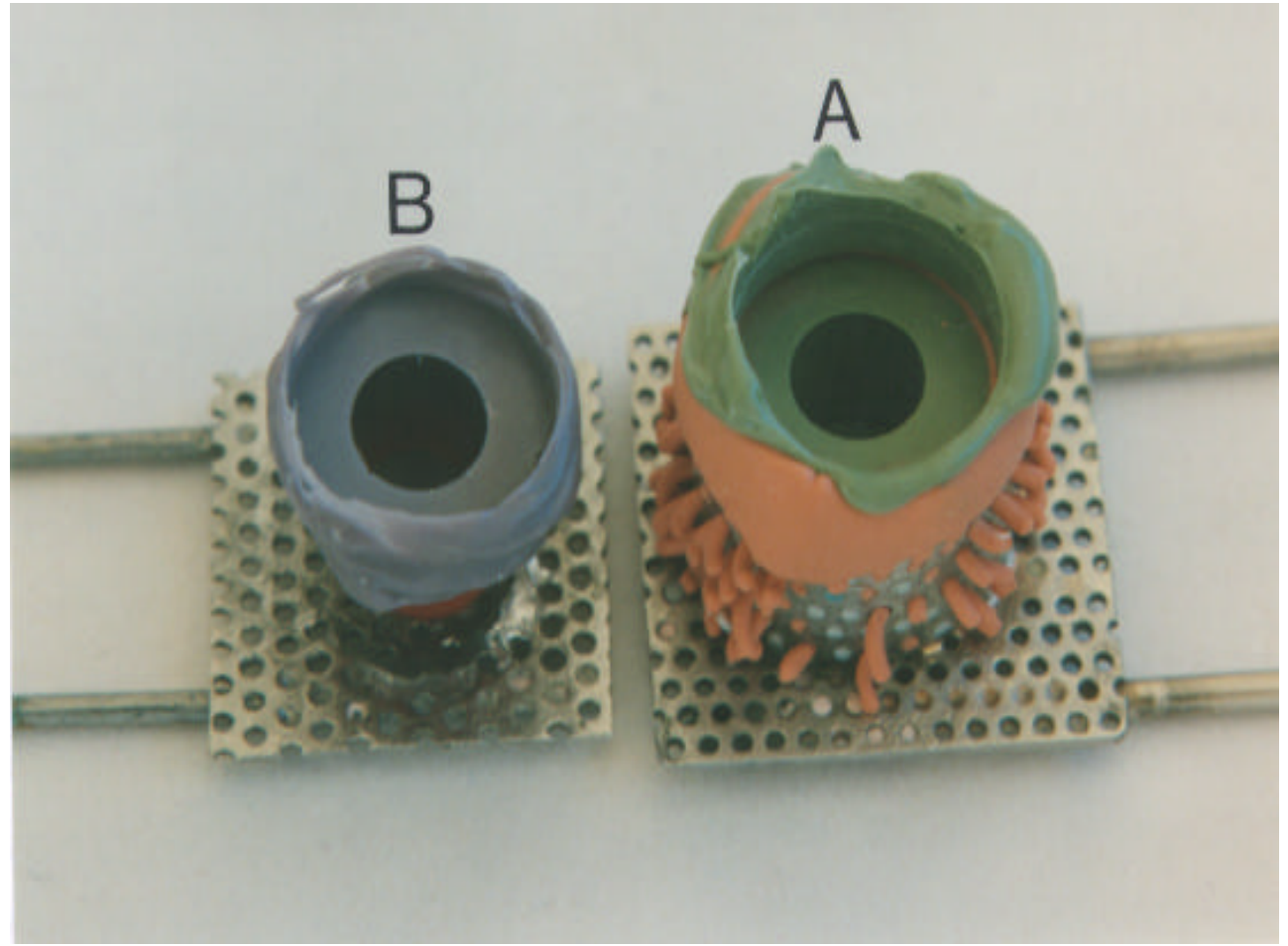

Figura 4.7 - Aspecto de um molde escolhido aleatoriamente, para a técnica da dupla moldagem (em A), e do casquete (em B), na forma descrita no texto. 


\section{3 - Confecção dos troquéis}

Após o período de "descanso", procedia-se à confecção do modelo (em gesso Vel-Mix), através de procedimentos iguais, para todos os moldes, independente de sua origem, quando era construído um dique ao seu redor, utilizando-se fita crepe adesiva de $1 \mathrm{~cm}$ de largura, o que permitiria a formação de uma base cilíndrica (de cerca $4 \mathrm{~mm}$ de espessura) no futuro troquel, água destilada ( $1 \mathrm{ml}$ medido em proveta) era colocada num gral próprio, o qual acompanha a máquina de manipulação à vácuo que foi usada; como as porções de gesso pedra Vel-Mix (4 g, pesadas em balança eletrônica Sartorius - Werke Ag - Germany) já haviam sido previamente acondicionados em pequenos sacos plásticos, uma destas era misturada com a citada quantia de água destilada, naquele gral, acoplado à maquina já mencionada, por 60 segundos, tempo este especificado pelo fabricante do gesso. A mistura resultante, em quantia suficiente para obtenção de um troquel, era vertida no molde, sobre vibração, até seu completo preenchimento, utilizando-se para isso um outro pincel $\mathrm{n}^{\circ} 2$ 2- 266. Aguardava-se 120 minutos, contados a partir do início da mistura, quando então a fita adesiva era removida do conjunto e o troquel era então separado do respectivo molde, um destes troquéis pode ser observado na figura 4.8 . 
Figura 4.8 - Aspecto de um troquel de gesso obtido (a seta aponta o ponto em depressão - marca das 12 horas).

Somente era realizada uma nova geração de moldagem, após o término do vazamento da mistura gesso-água recém espatulada no molde. Assim foram obtidos 90 troquéis, 10 para cada uma das condição experimentais especificadas. 


\section{4 - Medições dos troquéis}

Após 14 dias, contados a partir de sua confecção, os troquéis eram examinados com lupa e com uma lâmina de bisturi removia-se pequenas protuberâncias (resultantes de bolhas nos moldes), se presentes, que poderiam interferir na adaptação da coroa-padrão. Efetuava-se então a verificação do grau de fidelidade de cada troquel, através do emprego do coroa-padrão, já descrito anteriormente, a qual era colocado em cada troquel, para medição da adaptação daquele a este, tarefa que era efetuada com o auxílio de um microscópio de profundidade Carl Zeiss (Alemanha), cujo sistema ótico permitia aumento linear de $1,6 x$.

Era necessário um primeiro cuidado de que a bancada de trabalho onde o citado microscópio ficava apoiado estivesse nivelada, o que foi aferido com um dispositivo comum, denominado de nível de bolha. Um segundo cuidado era que, quando da medição da adaptação do anel a cada troquel, a face oclusal deste último estivesse também igualmente nivelada; para estabelecer tal condição, foi usado um verticulador comum (Bio-Art - São Carlos), cujo ramo superior foi removido e colocado sobre a bancada de trabalho, com sua face inferior voltada para cima; na porção mediana da parte útil desta face, o cilindro centralizador (também já anteriormente descrito) foi adequadamente fixado, com cola à base de cianoacrilato (Super Bonder, Loctite Brasil Ltda.), ficando sua abertura de maior diâmetro também voltada para cima, cuja luz também foi nivelada com o auxílio do nível de bolha, durante o ato de colagem; um troquel era então cuidadosamente colocado no cilindro centralizador, momento em que a haste-guia do ramo inferior do verticulador era feita encaixar no orifício próprio do ramo oposto; nesta parte inferior, encontrava-se firmemente acoplada uma peça de madeira (encaixada no entalhe retentivo lá existente); na superfície da madeira que se encontrava voltada para o ramo superior do dispositivo, era colocada uma pequena porção de massa de modelagem (do tipo usado para crianças brincarem), de cor verde, a qual ficava adequadamente presa naquele local; abaixava-se então o ramo inferior do verticulador, ao longo da sua haste-guia, até que a massa prendesse adequadamente a 
base irregular do troquel em questão, situação que está ilustrada pela figura 4.9; invertendo-se, naquele momento, o dispositivo, dele removia-se o ramo superior; portando então o troquel de gesso com sua face oclusal nivelada; neste momento (antes dele ser levado ao microscópio de profundidade, para a medição), a ele era cuidadosamente acoplada a coroa-padrão, de maneira semelhante à que foi descrita anteriormente para o troquel-padrão.

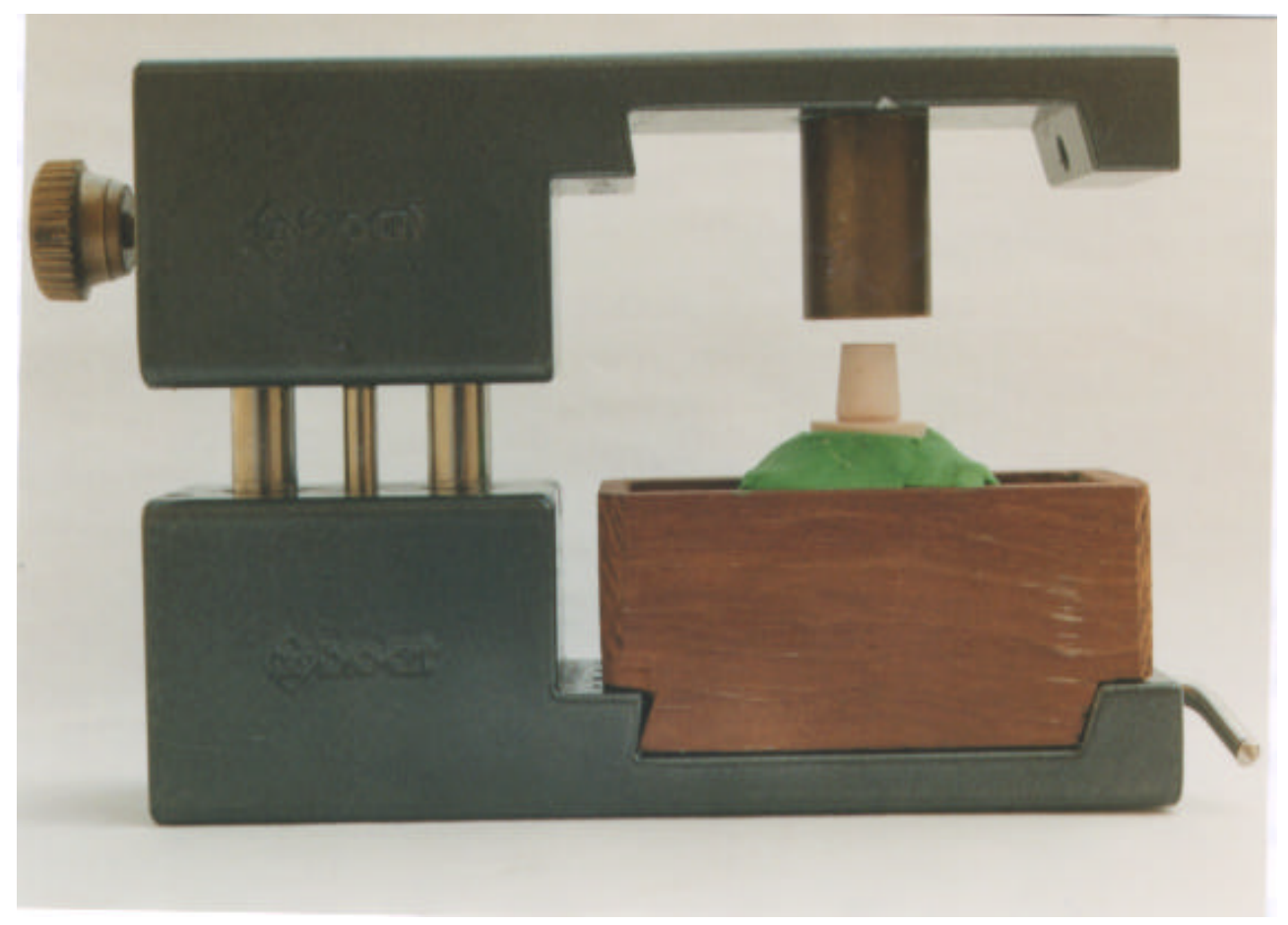

Figura 4.9 - Verticulador, com o cilindro centralizador fixado no seu ramo superior e com a peça de madeira (prendendo um troquel então nivelado, através da massa de modelar verde) presa ao ramo oposto.

A peça de madeira era então removida do ramo inferior do verticulador (após a retirada do pino metálico que a transfixava, prendendo-a àquela parte) e levada sob a lente objetiva do microscópio de profundidade, para a medição do troquel. Anteriormente, havia sido tomado o cuidado de que as faces superior e inferior desta peça estivesse paralelas entre si, mantendo-se sempre nivelada, quer quando fixadas no ramo do verticulador, ou quando ela fosse levada ao microscópio citado. 
Após uma primeira focalização grosseira (com o parafuso macrométrico do microscópio) da imagem observada, através do processo de tentativas, localizava-se primeiramente a região da borda superior da coroa-padrão referente à marca de 12 horas, ocasião em que o foco era novamente estabelecido, agora da maneira mais nítida possível, através do respectivo parafuso micrométrico; o número lido no anel deste último parafuso, correspondente à aquela altura, era registrado (em micrometro)) e ele era adequadamente girado até igualmente se ajustar nitidamente o foco da imagem da superfície oclusal do troquel, momento em que um segundo número era anotado, efetuava-se então a diferença entre os dois números registrados e o valor obtido era também anotado, acrescido do sinal positivo, no caso do metal encontrar-se mais alto que o gesso, e do sinal negativo, em caso contrário; este procedimento era também executado para as regiões das 3, 6, e 9 horas; repetia-se este ciclo inteiro por mais duas vezes e, para cada uma das quatros posições, também calculava-se o valor médio, sendo todos os valores citados devidamente anotados em ficha adequada.

Para cada troquel, o respectivo grau de fidelidade (expresso indiretamente pela quantidade de adaptação da coroa-padrão) era considerado como a média aritmética dos valores médios, em cada uma das quatro regiões em que foram executadas as operações de leitura, levando-se em consideração o fato de que o sinal que antecedia cada número (exceto o zero) significava que a coroa-padrão estava mais baixa que a face oclusal do troquel de gesso em análise, se negativo, ocorrendo o inverso no caso oposto.

Quanto aos valores da adaptação, a média aritmética dos valores médios, nos quatros pontos descritos, foi calculada para cada troquel de gesso, considerando-se o sinal; este era considerado o valor da adaptação de cada troquel. Os valores das 10 réplicas, para cada uma das 9 condições estabelecidas, foram tratados através de análise de variância à 1 critérios. Dada a significante diferença estatística observada, tornou-se necessária a aplicação de um teste de contrastes. 
5 - Resultados e discussão 


\section{5 - Resultados e discussão}

Pela revisão da literatura, pode-se obter uma noção geral do comportamento dos materiais elastoméricos para moldagem, no tocante a vários aspectos, ressaltandose, neste trabalho, a fidelidade morfo-dimensional dos troquéis de gesso obtidos. Cada material (dentre os elastômeros e gessos) apresenta características próprias e diferenças individuais que lhes conferem propriedades singulares. O sucesso clínico de seu uso está ligado a condições favoráveis, capazes de permitir a obtenção de peças protéticas adaptadas, do melhor modo possível, aos dentes preparados. Consequentemente, tal sucesso é dependente das pesquisas laboratoriais e da maneira pela qual os materiais são empregados pelo profissional, sem deixar-se de ressaltar a importância do conhecimento científico apurado e da destreza deste profissional.

As medidas médias originais da adaptação da coroa-padrão, nos quatro pontos estudados (12, 3, 6 e 9 horas), para cada réplica dos cinco materiais de moldagem, nas nove condições avaliadas encontram-se na tabela 9.1 do Apêndice; todos os valores encontram-se registrados em micrometros $(\mu \mathrm{m})$.

A figura 5.1 apresenta esquematicamente a distribuição dos valores expressos na tabela 5.1, em relação ao nível ideal (marca zero).

Os resultados médios individuais da adaptação da coroa-padrão nos troquéis de gesso, para os cinco materiais, nas duas técnicas testadas, com as respectivas médias e desvios-padrão encontram-se na tabela 5.1. Os resultados desta, expressam as alterações morfo-dimensionais, que ocorreram nas nove diferentes condições experimentais e reproduzidas nos respectivos troquéis de gesso, analisadas pela adaptação da coroa-padrão. 


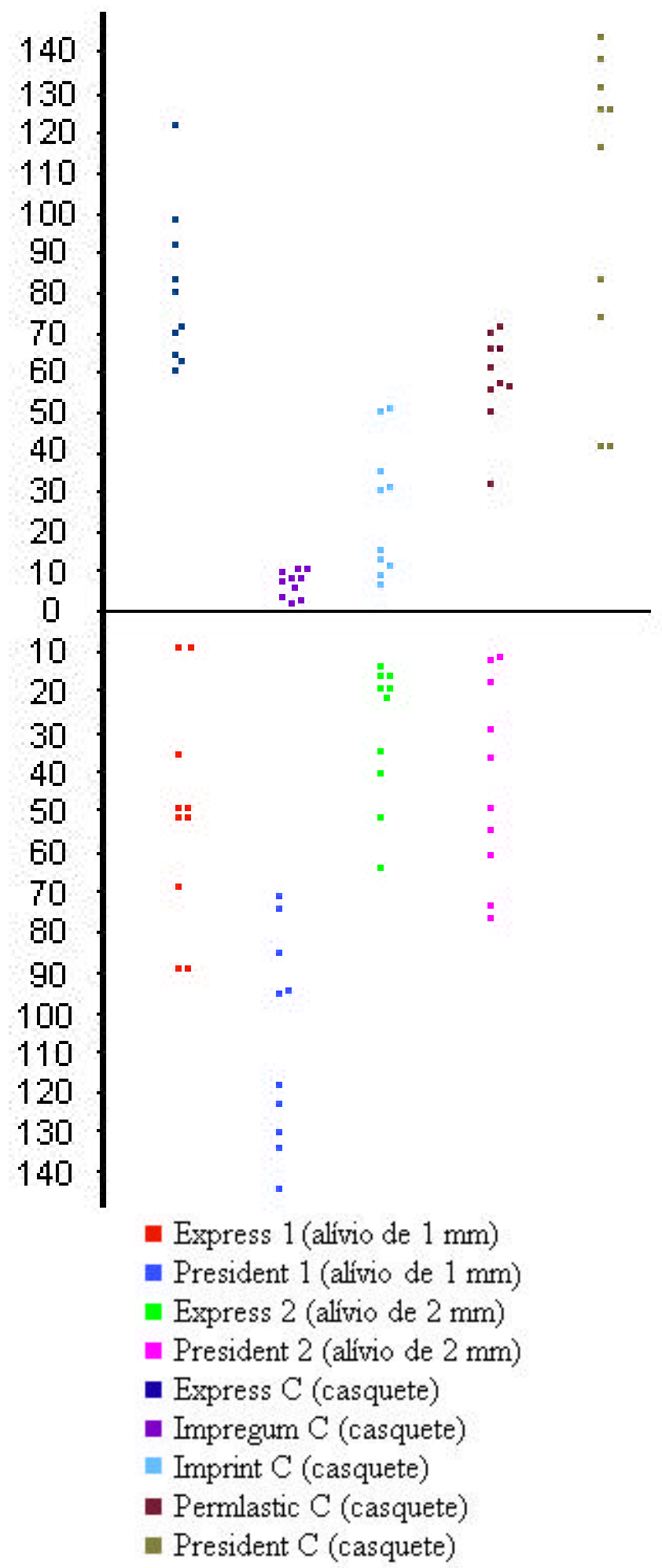

Figura 5.1 - apresenta esquematicamente a distribuição dos valores expressos na tabela 5.1, em relação ao nível ideal (marca zero). 


\begin{tabular}{|c|c|c|c|c|c|c|c|c|c|}
\hline T & Exp1 & Pre1 & Exp2 & Pre2 & ExpC & IpeC & IpiC & PrmC & PreC \\
\hline 1 & $-89,0$ & $-85,2$ & $-16,7$ & $-28,8$ & 121,9 & 6,9 & 30,3 & 50,0 & 138,0 \\
\hline 2 & $-53,9$ & $-135,6$ & $-20,8$ & $-12,6$ & 69,1 & 7,8 & 31,8 & 32,5 & 126,5 \\
\hline 3 & $-8,8$ & $-146,2$ & $-40,1$ & $-18,0$ & 65,7 & 4,1 & 9,0 & 56,1 & 84,5 \\
\hline 4 & $-52,8$ & $-123,3$ & $-64,0$ & $-56,8$ & 63,3 & 9,2 & 15,8 & 58,1 & 116,8 \\
\hline 5 & $-89,7$ & $-71,0$ & $-20,3$ & $-50,2$ & 99,5 & 10,3 & 13,3 & 57,0 & 126,4 \\
\hline 6 & $-50,1$ & $-96,4$ & $-21,0$ & $-58,9$ & 92,2 & 2,2 & 37,3 & 67,6 & 41,8 \\
\hline 7 & $-35,4$ & $-95,3$ & $-53,2$ & $-74,1$ & 71,4 & 8,8 & 49,9 & 61,8 & 144,4 \\
\hline 8 & $-50,8$ & $-130,6$ & $-18,7$ & $-11,4$ & 84,3 & 10,2 & 7,4 & 67,1 & 74,3 \\
\hline 9 & $-8,7$ & $-75,1$ & $-15,7$ & $-35,9$ & 80,4 & 3,3 & 50,8 & 72,9 & 41,9 \\
\hline 10 & $-68,2$ & $-118,1$ & $-35,6$ & $-77,8$ & 60,4 & 7,5 & 11,5 & 74,2 & 132,3 \\
\hline Média & $-50,74$ & $-107,68$ & $-30,61$ & $-42,45$ & 80,82 & 7,03 & 25,71 & 59,73 & 102,69 \\
\hline d.p & 28,013 & 26,528 & 16,972 & 24,653 & 19,313 & 2,891 & 16,585 & 12,305 & 39,060 \\
\hline
\end{tabular}

Tabela 5.1 - Resultados médios individuais (em $\mu \mathrm{m})$, com as respectivas médias, da adaptação da coroa-padrão nos troquéis de gesso, obtidos dos cinco elastômeros (Exp - Express; Ipe - Impregum; Ipi - Imprint; Prm - Permlastic; Pre President), nas duas técnicas de moldagem (1 - dupla moldagem com alívio de $1 \mathrm{~mm} ; 2$ - com alívio de $2 \mathrm{~mm}$ e $\mathrm{C}$ - casquete), como descrito no texto.

Foi aplicada uma análise de variância a um critério de classificação, modelo fixo, aos valores da tabela 5.1 e, esta, apontou o fato de existirem diferenças, a um nível de significância maior que $1 \%$, como mostra o quadro 5.1 .

\begin{tabular}{|c|c|c|c|c|c|c|}
\hline Adaptação & $\begin{array}{c}\text { Graus de } \\
\text { liberdade }\end{array}$ & $\begin{array}{c}\text { Quadrado } \\
\text { Médio }\end{array}$ & $\begin{array}{c}\text { Erro do grau } \\
\text { de liberdade }\end{array}$ & $\begin{array}{c}\text { Erro do } \\
\text { quadrado } \\
\text { médio }\end{array}$ & $\begin{array}{c}\mathrm{F} \\
\text { observado }\end{array}$ & $\begin{array}{c}\text { Nível de } \\
\text { probabilidade }\end{array}$ \\
\hline 1 & 8 & $47554,61^{*}$ & $81^{*}$ & $524,2177^{*}$ & $90,71538^{*}$ & $0,00^{*}$ \\
\hline
\end{tabular}

*significante $(\mathrm{p}<0,01)$

Quadro 5.1 - Resultado da análise de variância aplicada aos valores da tabela 5.1. 
Em função do resultado apontado pela análise de variância, foram efetuadas comparações, pelo teste de Tukey, cujos valores encontram-se no quadro 5.2; nele, podem ser observadas as comparações que pareceram ser as mais adequadas.

\begin{tabular}{|c|c|}
\hline Comparações & $\mathbf{t}_{\text {observado }}$ \\
\hline Pre1 x Pre2 & $0,000133^{*}$ \\
\hline Pre1 x Exp1 & $0,000141^{*}$ \\
\hline Pre1 x Exp2 & $0,000133^{*}$ \\
\hline Exp1 x Exp2 & 0,571095 \\
\hline Exp1 x Pre2 & 0,996329 \\
\hline Exp2 x Pre2 & 0,963179 \\
\hline PrmC x PreC & $0,002250^{*}$ \\
\hline PrmC x ExpC & 0,507618 \\
\hline PrmC x Ipi C & $0,03450 *^{*}$ \\
\hline PrmC x IpeC & $0,000183^{*}$ \\
\hline PreC x ExpC & 0,457026 \\
\hline PreC x IpiC & $0,000133^{*}$ \\
\hline PreC x IpeC & $0,000133^{*}$ \\
\hline ExpC x IpiC & $0,000152^{*}$ \\
\hline ExpC x IpeC & $0,000133^{*}$ \\
\hline IpiC x IpeC & 0,666158 \\
\hline Pre1 x PreC & $0,000133^{*}$ \\
\hline Pre2 x PreC & $0,000133^{*}$ \\
\hline Exp1 x ExpC & $0,000133^{*}$ \\
\hline Exp2 x WxpC & $0,000133^{*}$ \\
\hline
\end{tabular}

* significante

Quadro 5.2 - Comparações efetuadas pelo teste de Tukey, ao nível de significância de 5\%. 
Neste quadro, ao analisar inicialmente apenas os valores referentes à técnica da dupla moldagem (6 primeiras linhas do quadro), pode-se observar que a condição President - $1 \mathrm{~mm}$ de alívio (média-107,68) foi significantemente pior de todas as 3 demais condições. Já estes 3 últimos, em quaisquer comparações entre si, apresentaramse com resultados semelhantes. Em outras palavras, o President (com alívio de $1 \mathrm{~mm}$ ) foi o de pior desempenho dentro deste grupo; o Express (-50,74 e -30,61, respectivamente) não apresentou resultados diferente, quando usado nas 2 espessuras (1 ou $2 \mathrm{~mm}$ ), conduzindo a valores iguais ao do President $(-42,45)$ com alívio de $2 \mathrm{~mm}$.

Analisando-se em seguida apenas a técnica do casquete (desde a $7^{\mathrm{a}}$ até a $16^{\mathrm{a}}$ linha), existiu diferenças significante para a maioria das comparações; a primeira semelhança ocorreu na comparação do Permlastic $(59,73)$ com o Express $(80,82)$; a segunda ocorreu entre o President $(102,69)$ e o Express e a última entre o Imprint $(25,71)$ e o Impregum F (7,03). Explicando de outro modo, o President apresentou um mau desempenho, semelhante ao Express, porém diferente dos demais; o Express, entretanto, apresentou-se como o Permlastic, porém sendo ambos piores que o Imprint e o Impregum; estes dois últimos conduziram aos melhores resultados, de maneira semelhante.

Finalmente, analisando-se apenas os 2 últimos elastômeros usados em ambas as técnicas (quatro últimas linhas), sempre foram observadas diferenças significantes em todas as comparações efetuadas. Explicando de outra forma, o President, com alívio de $1 \mathrm{~mm}$, na técnica de dupla moldagem apresentou pior resultado do que o mesmo material usado com a técnica do casquete; já o President, com alívio de $2 \mathrm{~mm}$, teve um desempenho melhor que a sua condição com casquete. Para o Express, ambos os alívios conduziram a resultados melhores que a sua condição com casquete.

Em uma análise global, pode-se ordenar todas as condições estudas em ordem decrescente de valores de adaptação, em módulo, como mostra o quadro 3. 


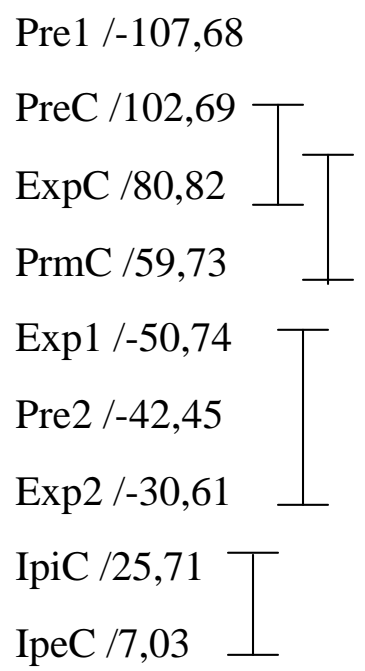

Quadro 5.3 - Valores da adaptação da coroa-padrão, em módulo, ordenados em ordem decrescente, de cima para baixo, para todas as comparações efetuadas. As barras verticais indicam os grupos com desempenho estatisticamente semelhantes entre si.

Neste aspecto geral, pode-se observar que o pior resultado foi obtido com o President na condição Pre1 $(-107,68)$. A condição PreC $(102,69)$ foi semelhante à do ExpC $(80,82)$, porém diferente da PrmC $(59,73)$; estas duas últimas apresentaram desempenhos semelhantes entre si. Com melhores desempenho que as anteriores, apresentaram-se as condições Exp1 $(-50,74)$, Pre2 $(-42,45)$ e Exp2 $(-30,61)$, todas com comportamento bastante próximos entre si. O melhor desempenho coube aos grupos IpiC $(25,71)$ e Ipe $(7,03)$, com desempenho praticamente semelhantes.

De acordo com a revisão de literatura, nota-se que há vários métodos para se avaliar a precisão morfo-dimensional dos materiais de moldagem, o que tem proporcionado a busca de uma metodologia que favoreça a compreensão dos resultados e sua aplicação clínica.

Os testes para avaliar a precisão dimensional e outras características dos materiais de moldagem enquadram-se geralmente, segundo STACKHOUSE JR. ${ }^{142}$, dentro de uma ou mais categorias, podendo ser linear, com as medições efetuadas 
diretamente nos moldes ou indiretamente nos respectivos troquéis de gesso, ou ainda, através de métodos nos quais a precisão do material de moldagem é indiretamente estabelecida, pela avaliação da adaptação de uma coroa-padrão no troquel de gesso especial. Uma vantagem aparente deste último método é que a abertura na porção oclusal da coroa-padrão permite a possibilidade de mensurar-se a discrepância dos troquéis que apresentem um diâmetro maior ou menor que o original. O método que emprega coroas, sem a citada abertura são efetivos, apenas para avaliar a adaptação marginal, somente no caso do diâmetro do troquel de gesso ser maior do que o do original; entretanto, se este diâmetro for menor, tal método deixa de ser confiável.

O método empregado na presente pesquisa permitiu uma análise do material de moldagem a partir de uma reprodução, em gesso especial, do troquel-padrão metálico e, consequentemente, a avaliação da adaptação de uma coroa-padrão metálica àquela, possibilitando observar as alterações dimensionais dos elastômeros. Para PHILLIPS ${ }^{121}$, este tipo de método pode ser utilizado com segurança. Comparando métodos para a avaliação das alterações dimensionais dos elastômeros, segundo a especificação no 19 da A. D. A. ${ }^{3}$, avaliando-se a precisão de troquéis de gesso obtidos com diferentes materiais de moldagem, EAMES et al. ${ }^{60}$ observaram uma alta correlação (99\%) das alterações dimensionais dos elastômeros com desajuste de coroas-padrões aos troquéis de gesso, enquanto que, FINGER; OSAWA ${ }^{66}$ relataram não ter encontrado correlação (alta) entre a contração de polimerização livre, das siliconas estudadas, e a precisão dos modelos de gesso obtidos, salientando que o fenômeno relacionado às contrações, que ocorrem com as siliconas, confinadas ou não, poderia ocorrer quando em moldeiras, sob influência de propriedades específicas ou reológicas, pela espessura do material na moldeira, tipo de retenção e plasticidade do material, e que a contração de polimerização livre, por si só, pode não ser parametro, adequado, para determinar a precisão de um material elastomérico. Quando uma análise mais crítica do material de moldagem é desejada, a utilização de um troquel metálico, com um segmento retentivo abaixo do limite cervical periférico do preparo, do tipo coroa total, constitui um detalhe importante para determinar pequenas diferenças existentes entre os materiais de 
moldagem. Segundo SCHNELL; PHILLIPS ${ }^{135}$, este pormenor possibilita a observação adicional de distorções, pela deformação permanente do material, durante a remoção do molde e a recuperação elástica inerente e, a ausência de área retentiva reflete mais a distorção decorrente da polimerização do elastômero e da expansão de presa do gesso.

A mensuração das alterações dimensionais de troquéis de gesso, estabelecida pelo ajuste de um elemento usinado (coroa-padrão) de referência, tem sido efetivada em diferentes pesquisas, com auxílio de microscópio de profundidade, o que possibilita analisar o desajuste positivo ou negativo, a partir da superfície oclusal desta e a do troquel.

O troquel-padrão metálico, tronco-cônico, têm sido utilizado, amplamente, por diversos autores $5,6,7,8,11,28,99,144,149$, principalmente, por se manter inalterado nas diferentes fases do experimento, permitindo a reprodução sucessiva por diferentes materiais e técnicas de moldagens e, a obtenção de modelos de gesso, resina, ou outros materiais, correlacionando a adaptação precisa de um anel ou coroa-padrão, usinada ou fundida, com abertura oclusal, com a obtida em modelos reproduzidos. Por outro lado, a adaptação de coroas totais fundidas, obtidas a partir de moldes de dentes naturais, tem sido estabelecida pelo ajuste cervical, desde que as mesmas não apresentem abertura oclusal, o que não permite a avaliação da influência do material ou da técnica de moldagem, caso o troquel apresente diâmetro menor que o diâmetro interno da coroa.

O dispositivo de moldagem, apresentado por ARAÚJO; JORGENSEN ${ }^{6}$, constituído de um troquel de aço tronco-cônico, ao qual se adapta precisamente uma coroa ou anel de aço usinado com abertura oclusal, foi empregado na presente pesquisa, objetivando o estudo comparativo entre os diferentes materiais e técnicas de moldagens. O emprego deste, para avaliação dos materiais de moldagem e de gessos para troquéis, constituí uma metodologia bastante simples e compatível com as tradicionalmente empregadas, segundo, ARAÚJO $^{7}$ e BONACHELA ${ }^{28}$. 
MARCHESE $^{97}$ avaliou a adequação de dois métodos de mensuração da fidelidade morfodimensional de troquéis de gesso, obtidos a partir de moldes de elastômeros, estabelecendo a medição direta das dimensões do diâmetro (perfil) com auxílio de um microscópio de medição, em comparação com o grau de adaptação de uma coroa-padrão ao troquel, usando microscópio de profundidade. A análise do perfil não mostrou correlação favorável com o método que avaliava o grau de adaptação coroa padrão/troquel, uma vez que valores negativos, para as várias alturas consideradas no troquel, observados pela análise do perfil, não implicaram em desajuste negativo quando da observação da coroa padrão, considerando que o sistema de medição do perfil não é confiável, nem adequado, por possuir grande margem de erro ou por não detectar precisamente distorções setoriais dos troquéis de gesso, que possam ter ocorrido em função do material de moldagem.

Os resultados médios individuais (em $\mu \mathrm{m})$ com as respectivas médias e desvios padrão, da adaptação da coroa-padrão nos troquéis de gesso, obtidos para os nove grupos experimentais avaliados, empregando as duas técnicas de moldagem (dupla moldagem com alívio de 1 e $2 \mathrm{~mm}$ e do casquete) estão na tabela 5.1. Podendo-se observar pelas médias que, em maior ou menor grau, todos os materiais sofreram alterações morfo-dimensionais, refletidas diretamente nos troquéis de gesso e, conseqüentemente, na adaptação da coroa-padrão. Vários têm sido os fatores que afetam a precisão dimensional dos moldes obtidos com os diferentes materiais de moldagem, tais como: espessura do material de moldagem $6,7,13,22,60,71,91,100,119,124,146$, adesão à moldeira $^{13,22,26,30,38,52,68,100,119,152}$, direcionamento da contração de polimerização do material de moldagem ${ }^{12,13,22,24,67,68,79,86,115,120}$, tempo de polimerização e vazamento do molde $^{2,27,45,60,81,90,100}$, coeficiente de expansão térmica linear do material de moldagem e da moldeira ${ }^{22,26,33,70,79,85,100}$, presença de áreas retentivas nos preparos ${ }^{6,10,22,33,68,82}$, recuperação elástica do material ${ }^{22,24,33,63,86,100,101,140}$, e direção de remoção da moldagem $^{22,34,52,68,77,140}$. 
Verifica-se, que são várias as influências que um material de moldagem pode sofrer, durante e após a confecção do molde, que irão contribuir em maior ou menor grau para as alterações dimensionais deste e, consequientemente, nos respectivos troquéis. Algumas dessas influências, consideradas de maior relevância, no presente trabalho, serão discutidas a seguir.

A tendência natural quando do reembasamento de um molde, com o material fluído, é a obtenção de um troquel diminuído ${ }^{33,67,125,143}$, em função do material de reembasamento induzir uma pressão interna no primeiro molde, o que proporciona, na recuperação elástica do mesmo, uma projeção espontânea juntamente com o material utilizado para a moldagem complementar, diminuindo o diâmetro interno do molde e levando à obtenção subseqüente de um troquel menor após o vazamento do gesso. Várias propostas têm sido divulgadas, com o intuito de minimizar este problema; como o alívio total do molde, confecção de canais de escoamento neste, técnica simples laminada para materiais com diferentes consistências, no sentido de favorecer o escoamento do segundo material, na tentativa de diminuir pressão adicional. De acordo com CHEVITARESE, SCELZA; AMARANTE ${ }^{40}$, durante o reembasamento sem alívio, não há como prover um espaço para o material de moldagem propriamente dito, criando-se dificuldade crescente para escoamento ou fluxo do material fluído, a partir da face oclusal, onde o material torna-se mais abundante e, dependendo da sua consistência ou do grau de polimerização, estabelece uma dificuldade ainda maior para o escape e assentamento adequado do primeiro molde. Na presente pesquisa, na técnica da dupla moldagem, procurou-se criar, de forma padronizada, alívios de 1 e $2 \mathrm{~mm}$, para o escoamento do excesso do material fluído aplicado na segunda moldagem, procedimento este clinicamente viável e de fácil execução. Portanto, além do tipo de material ter influência na precisão dos moldes, o alívio pode acarretar uma influência distinta, envolvendo as características intrínsecas do próprio material. EDUARDO; MATSON; FICHMAN ${ }^{62}$, avaliando a alteração dimensional das siliconas em 
moldagens com e sem alívios, observaram que dependendo da quantidade do alívio poderão ocorrer alterações acentuadas na obtenção dos moldes e, subseqüentemente, no troquel e na fundição. Este comportamento dimensional, provavelmente, possa explicar, sob o ponto de vista clínico, as dificuldades encontradas no ajuste das estruturas fundidas, quando da realização de dupla moldagem (material denso e fluído) as quais poderão ser agravadas se o profissional não conseguir compensar esta alteração, que na prática torna-se um procedimento até certo ponto empírico, devido ao desconhecimento da magnitude destas alterações, com as possíveis compensações laboratoriais. Assim, mesmo para as siliconas de adição, que apresentam uma menor alteração dimensional, tem sido indicada uma moldagem simultânea entre o material de consistência pesada e leve, na tentativa de minimizar a indução de tensões que ocorrem durante o reembasamento ${ }^{67}$. Os alívios favorecem o escoamento do material e uma menor indução de tensões, por possibilitar a saída progressiva do material no momento do reembasamento, sem o seu represamento no espaço correspondente ao preparo. Podemos confirmar esta tendência (figura 1), para todos os modelos obtidos, pela técnica da dupla moldagem, para ambos os alívios, onde o de $2 \mathrm{~mm}$ produziu troquéis de gesso menores do que o original, mas, mais próximo a este do que aqueles obtidos com o de $1 \mathrm{~mm}$, o que nos leva a crer que a presença de um alívio maior, permitirá um maior espaço para o material que será empregado na segunda moldagem e, mais facilidade no escoamento deste e, conseqüentemente, menor pressão hidráulica sobre o primeiro molde, tendência estas confirmadas por SNEED et al. ${ }^{138}$. Verificou-se ainda, um comportamento distinto para o Impregum F e para o Imprint, enquanto as siliconas na técnica da dupla moldagem mostraram um tendência de reduzir os troquéis de gesso em relação ao original, com uma acentuação nesta diminuição para o President, alívio de $1 \mathrm{~mm}$, o inverso ocorreu para os troquéis obtidos com todos os materiais na técnica do casquete, os quais apresentaram-se sempre maiores do que o original. Portanto, além do tipo de material poder influenciar na precisão dos moldes, a técnica poderá acarretar 
uma influência distinta, envolvendo as características intrínsecas do próprio material e a adequação da técnica em si dentro da precisão necessária para favorecer as etapas de ajuste e cimentação.

BELL; FRAUNHOFER ${ }^{22}$, aconselham o emprego da moldeira individual sempre que possível, pois esta permite uma melhor uniformidade na espessura do material de moldagem, conseqüentemente, resulta em um molde mais fiel, apesar de TJAN $^{144}$, afirmar que a quantidade de alívio não afeta a precisão dimensional do material de moldagem e PINTO et al. ${ }^{122}$, observarem que o desajuste cervical das infraestruturas metálicas eram menores, quando se empregavam moldeiras individuais. Segundo VALLE ${ }^{148}$, o aumento na espessura do material de moldagem na moldeira, de 1 para 4 milímetros, altera de forma significativa o comportamento dimensional do elastômero. Embora esta espessura possa ser válida quando se empregam casquetes individuais para moldagem, propiciando uma melhor precisão dos moldes, torna-se mais difícil consegui-la com as moldeiras individuais, aceitando-se clinicamente espessuras de até 3 milímetros para os materiais de moldagem ${ }^{28}$. Verifica-se ainda que essas alterações podem se processar de formas distintas, ARAÚJO; JORGENSEN ${ }^{8}$, BORGES FILHO $^{29}$, CONTIN; UETI $^{49}, \mathrm{CRAIG}^{52}$, observaram que os troquéis de gesso tipo IV, obtidos a partir de moldes de diferentes materiais de moldagem, apresentavam diâmetro maior que o troquel metálico padrão, embora a altura gengivo-oclusal tendesse a ser menor em função do direcionamento da contração do material de moldagem junto às paredes da moldeira, principalmente quando se tem uma maior espessura do material ${ }^{6}$.

Dos materiais pesquisados, o poliéter (Impregum F) constitui o de maior viscosidade ou consistência, que teria por este aspecto, maior dificuldade de escoamento. De acordo com TOLLEY; $\mathrm{CRAIG}^{147}$ e COMBE; MOSER ${ }^{48}$, o poliéter, embora seja um material com elasticidade próxima ao ideal, apresenta uma flexibilidade comparável a da mercaptana de consistência pesada. O módulo de elasticidade ou rigidez dos poliéteres, mostra-se em maior grau quando comparado aos demais 
elastômeros, o que requer um maior esforço para a remoção ou deslocamento do molde, principalmente, quando da presença de áreas retentivas, como na presente pesquisa, onde o troquel-padrão metálico, apresentava no terço cervical, uma área retentiva, o polissulfeto, deslocava-se com maior facilidade, devido a sua maior flexibilidade, o que não ocorria com os demais (Siliconas de adição e poliéter).

Os elastômeros apresentam uma boa recuperação elástica, a deformação permanente do poliéter é de $1-2 \%^{52}$, a da silicona de adição é de 0,02 a $0,7 \%$, após a polimerização $^{153}$ e a do polissulfeto de $3-5 \%^{52}$. Assim, fica evidente que, para materiais mais rígidos, como no caso das siliconas de adição (Express e President), na técnica da dupla moldagem, há a possibilidade de maior alteração dimensional, por distorção, pela ação da tensão induzida, resultante da segunda moldagem, além, da envolvida no ato do deslocamento do molde, dificuldade que implica em uma deformação que altere a memória elástica do material, retardando em período variado a recuperação do mesmo e levando a obtenção de troquéis com diâmetros alterados.

O material de moldagem deve estar firmemente aderido à moldeira, segundo $\mathrm{BOMBERG}^{26}$, o deslocamento deste, durante a polimerização ou de sua remoção da boca, resultará em alterações dimensionais e, conseqüente, distorção do modelo de gesso. Para a efetividade, desta aderência, pode-se empregar meios mecânicos, químicos ou uma combinação de ambos. CHAI et al. $^{38}$, investigando a resistência à tensão na força de união dos adesivos para os materiais de moldagem, observaram que a silicona de adição apresentou uma fraca união às moldeiras confeccionadas em resina acrílica, e que o polissulfeto e o poliéter apresentaram uma melhor força de união à estas. HOUGAN; AGAR $^{78}$, em sua pesquisa, observou que a força de união entre o adesivo e a silicona de adição (Express), foi significante maior do que a do Permlastic, e que o sistema adesivo deste material tem sua força de união diminuída significantemente quando se cria um alívio, com cera, na moldeira de resina acrílica. 
PAYNE; PEREIRA ${ }^{117}$, observaram que as moldeiras individuais melhoram a precisão dos modelos de gesso, que existem vários materiais para a confecção destas, uma grande variedade de agentes adesivos, e que, a adesão do material de moldagem à moldeira depende do tipo do material empregado em sua confecção e da rugosidade de sua superfície. A retenção do adesivo à moldeira, depende da habilidade de seu solvente dissolver a resina da moldeira. A força de união das moldeiras confeccionadas com resinas termo-polimerizáveis e das autopolimerizáveis são similares, mas outras variáveis que poderão influir nesta força de união, também, devem ser levadas em consideração, tais como: direção e força de remoção do molde da boca, flexibilidade do resina e, contaminação da superfície da resina antes da aplicação do adesivo. Para DAVIS et al. ${ }^{57}$., na remoção do molde da boca, o material de moldagem e sua união com a moldeira, sofrem stress, sendo esta força de união de vital importância para a precisão do molde, do troquel e subseqüentemente da fundição. Alguma técnicas com a finalidade de criarem um espaço adequado para o material de moldagem, tem sido difundidas, tais como: o emprego de uma lâmina de cera, amianto ou de alumínio. Uma outra sugestão apresentada é criar uma rugosidade na resina, que se confecciona a moldeira individual, com a finalidade de aumentar a retenção do agente adesivo. Os autores observaram que esta rugosidade, influência diretamente a força de união do adesivo do polissulfeto, e as falhas que ocorreram foi na interface do material de moldagem e do adesivo, o tempo de secagem deste, também, influenciará a força de união entre o adesivo e o material da moldeira. Na silicona e no poliéter a fratura coesiva ocorre antes do material adesivo se desprender da moldeira. Segundo GRANT; $\mathrm{TJAN}^{68}$, a adesão do elastômero à moldeira é um fator importante e que poderá afeta a precisão da restauração fundida. Para estes, o adesivo do poliéter e da silicona de adição são consistentemente mais fortes do que o do polissulfeto e o da silicona polimerização por condensação e o local exato em que ocorre a desunião é de difícil localização, entretanto, com a silicona de adição, a ruptura, geralmente, ocorre na interface 
adesivo/elastômero, resultados similares foram obtidos com o polissulfeto, com uma quantidade maior de adesivo permanecendo na moldeira; para o poliéter a falha foi, eminentemente, coesiva. BOMBERG et al. ${ }^{26}$ observaram que a localização, tamanho e direcionamento das perfurações, das moldeira de estoque, influenciam diretamente a adesão do material à moldeira, e que as perfurações paralelas e perpendiculares ao eixo de inserção da moldeira, melhoram a retenção do material de moldagem.

Um outro fator a ser considerado é o direcionamento da contração de polimerização dos elastômeros, como resultado da redução no volume, devido às ligações cruzadas, por si só, proporciona alterações que afetam as dimensões verticais e horizontais estabelecidas no troquel-padrão. Este direcionamento da contração de polimerização contribui para a alteração dimensional que cada material pode sofrer. Como podemos ver no quadro 5.2, a análise estatística apontou para uma menor alteração dimensional para os troquéis de gesso obtidos, pela técnica do casquete, para os materiais Impregum F e Imprint, vindos a seguir o Express (alívio de 1 e 2 mm) President $(2 \mathrm{~mm})$ e o Permlastic, que teve um desempenho semelhante ao Express (técnica do casquete), o qual se comparou em semelhança ao President, para a mesma técnica. O pior resultado coube ao President (alívio de $1 \mathrm{~mm}$ ). Em uma avaliação do ajuste cervical de coroas totais fundidas obtidas a partir de moldes de silicona, poliéter e polissulfeto. CONTIN; $\mathrm{UETI}^{49}$, também, obtiveram em seu trabalho, médias das dimensões dos troquéis de gesso, obtidos com as técnicas de moldagem com o casquete e moldeira individual, com o Permlastic, bem maiores do que o original, principalmente na região cervical, enquanto a altura gengivo-oclusal dos corpos de prova mostrou ligeira contração e, a largura oclusal, uma expansão relativamente pequena. Para EAMES et al. ${ }^{60}$, destacaram que um padrão de cera feito em um troquel expandido resultará em fundição com dimensões maiores, quando comparadas com o preparo original, não sendo, necessariamente, esta condição observada clinicamente em função de outras discrepâncias que são introduzidas no processo de fundição. Consideram ser 
errônea a utilização de um troquel muito expandido, sendo preferível um troquel próximo do original. VALLE ${ }^{148}$, observou que o poliéter possibilitou a menores desajustes das coroas do que a mercaptana, tanto para moldeira ou casquete individual, relacionando esta superioridade à melhor estabilidade dimensional do poliéter, o que também é observado nesta pesquisa. Pesquisa de SAWYER et al. ${ }^{131}$, aponta as alterações dimensionais de diferentes elastômeros, envolvendo polissulfetos com ou sem peróxido de chumbo e um poliéter. Essas alterações podem se processar de formas distintas. Fica evidente, por trabalhos de LEWINSTEIN; CRAIG $^{91}$, que existe uma relação direta entre as alterações vertical e horizontal; portanto, quando a alteração horizontal apresenta um valor negativo (contração), a alteração vertical terá um valor positivo (expansão) e vice-versa. Embora não exista uma avaliação sistematizando a alteração dimensional de troquéis, nas diferentes extensões, $\operatorname{MARCHESE}^{97}$, quando analisou em microscópio comparador as medidas de troquéis de gesso (perfil) obtidos a partir de um troquel metálico padrão, pôde mostrar, pela tabela apresentada, uma tendência de maior alteração (positiva) na região central dos troquéis do que nas regiões oclusal e cervical, que poderia ser justificada pela relação direta entre as alterações vertical e horizontal induzidas no molde, mas que, de acordo com o autor, não permitiu correlação com os resultados de adaptação da coroa padrão aos troquéis obtidos.

Com base nos trabalhos de ARAÚJO; JÖRGENSEN ${ }^{8}$, TEIXEIRA ${ }^{146}$, em que o reaquecimento dos moldes, embora tenha alterado as dimensões dos troquéis de gesso, o fez diminuindo os respectivos diâmetros, sendo em alguns espécimes observados valores negativos, tanto para espessuras de 1 como para 4 milímetros, o que, do ponto de vista prático, poderia dificultar o ajuste de uma fundição junto ao preparo original. Por outro lado, MARCHESE ${ }^{97}$, em trabalho com metodologia semelhante, encontrou que o pior desempenho foi observado quando do vazamento dos moldes à $37^{\circ} \mathrm{C}$, tanto para o Permlastic quanto para a silicona de adição Provil $\mathrm{H}$. Embora haja discussão sobre a efetividade de métodos, como o reaquecimento, para 
favorecer a obtenção de moldes com maior precisão, nota-se que este procedimento não tem tido ampla indicação nos procedimentos laboratoriais, provavelmente por falta de uma definição precisa de sua efetividade e da dificuldade de controle das possíveis alterações, face às características individuais dos diferentes elastômeros, uma vez que cada produto comercial pode apresentar um tipo de comportamento ou alteração dimensional frente ao reaquecimento. O direcionamento da contração de polimerização dos elastômeros para as paredes da moldeira, como resultado da redução no volume devido às ligações cruzadas, por si só proporciona alterações que afetam as dimensões verticais e horizontais estabelecidas no troquel metálico padrão. Verifica-se assim que as características inerentes ao material de moldagem, envolvendo composição específica, escoamento e recuperação elástica, contribuem diferentemente na porcentagem de alteração dimensional que cada material pode sofrer.

STACKHOUSE JR. ${ }^{142}$, observando as dimensões vertical e horizontal de troquéis de gesso obtidos de moldes de polissulfeto e de silicona, a partir de troquéis de aço, notou que os troquéis produzidos com os moldes de silicona não apresentaram diferença estatisticamente significante, tanto no sentido vertical como horizontal. Entretanto, a moldagem com polissulfeto mostrou a maior variabilidade no sentido vertical quando da comparação individual dos troquéis. JOHNSON; CRAIG ${ }^{82}$ mediram a alteração dimensional de materiais de moldagem à base de polissulfeto, siliconas de reação de polimerização por condensação, por adição e poliéter, observando que não houve diferença significante na alteração dimensional horizontal, entre os suportes de uma prótese fixa, para todos os materiais analisados. Entretanto, para os troquéis unitários as dimensões horizontais estavam aumentadas para a silicona por adição e polissulfeto, mostrando-se em pequeno grau ou inalterado para a silicona por condensação e poliéter. As dimensões verticais para todos os troquéis apresentaram-se menores, sendo que a silicona por adição mostrou a menor alteração. Destacam, igualmente, que o diâmetro dos troquéis de gesso é geralmente maior do que o do 
troquel metálico padrão, em função do material de moldagem contrair em direção às paredes da moldeira durante a polimerização; usando o mesmo argumento, salientaram que o adesivo aplicado à moldeira individual pode limitar a direção de contração de polimerização, causando um aumento no espaço horizontal do molde. Portanto, a porção oclusal do preparo, estando mais próxima da camada de adesivo do que na porção gengival, poderia resultar num troquel mais largo na superfície oclusal.

PAMENIUS; OHLSON ${ }^{115}$, destacam que a remoção ou separação do molde induz, adicionalmente, deformação do elastômero, principalmente em áreas de retenção, assim como a fricção entre o dente e o material de moldagem, sendo que esse esforço estima a energia de separação requerida para remoção da moldeira. HONDRUM $^{77}$ observou um aspecto importante a ser considerado quando da remoção de uma moldagem, salientando que a tensão gerada durante a separação molde/preparo tenderia a se deslocar em extensão na porção cervical, o que induziria uma alteração dimensional e conseqüente fechamento das margens de uma coroa fundida, em função de deformações permanentes geradas nos diferentes materiais de moldagem e que se relacionam à natureza viscoelástica dos mesmos, sendo maiores para o polissulfeto e mínimas para a silicona por adição seguida pelo poliéter, o que vem ao encontro dos resultados observados no trabalho em questão. KOBAYASHI ${ }^{86}$ notou que a precisão dimensional do polissulfeto é insatisfatória, principalmente quando a moldagem é realizada em preparos com presença de áreas retentivas, tendo encontrado nestas situações altas magnitudes de alteração dimensional, com deformação na direção vertical e notável aumento do diâmetro, o que foi observado em todos os troquéis obtidos com polissulfeto, enquanto para a silicona de reação de polimerização por adição o comportamento, tanto em preparos com paredes laterais paralelas ou cônicas e com retenção cervical, mostrou melhor precisão dimensional, tanto em termos de alteração vertical como horizontal. Para o Permlastic Regular, utilizado igualmente nessa pesquisa, essa característica de maior alteração dimensional pode ter sido 
exacerbada pelo tipo de preparo, que possuía na região cervical uma inclinação retentiva correspondente à região entre o preparo e a porção radicular, e uma menor alteração para o Provil.

Embora diferentes trabalhos apresentem o polissulfeto como o elastômero que sofre maiores alterações dimensionais quando da obtenção de um molde, provavelmente pelo tipo de reação de polimerização e ligações cruzadas que continuam por algumas horas após o endurecimento inicial e formação de água como subproduto, continua sendo, após as siliconas de condensação, um dos materiais mais utilizados pelos profissionais brasileiros ${ }^{61}$. Conforme o observado, verifica-se que os troquéis obtidos a partir de moldes confeccionados com o Permlastic mostraram dimensões maiores do que o troquel padrão, o que implicaria em um troquel expandido e conseqüentemente fundição com maiores dimensões internas e facilidade de adaptação junto ao preparo estabelecido, o que de certa forma justificaria essa preferência por parte dos profissionais, além do fator custo, uma vez que dos três tipos de elastômeros constitui o de menor valor para aquisição. De acordo com os resultados de BONACHELA $^{28}$, a obtenção de troquéis de gesso expandidos ou com dimensões maiores não implica, por si só, melhor adaptação dos elementos fundidos. Analisando a adaptação tanto da coroa padrão em troquéis obtidos a partir de diferentes gessos como pela confecção de padrões de cera nos diferentes troquéis e posterior fundição desses elementos, para serem adaptados no troquel metálico de referência, não observou melhor adaptação com as fundições obtidas a partir de troquéis maiores, justificando que, ao ser realizado o processo de fundição, introduz-se um complexo grupo de variáveis como: cera odontológica, revestimento, fundição da liga metálica, metodologia empregada, e que os efeitos destas variáveis são imprevisíveis, de acordo com a opinião de ANUSAVICE ${ }^{4}$. De forma similar, ARAUJO ${ }^{5}$ observou que o processo de fundição apresenta uma variabilidade muito grande, o que pode diluir a melhoria obtida com materiais de moldagem mais precisos, salientando que os 
profissionais poderão adquirir materiais de moldagem mais modernos e precisos sem, no entanto, encontrarem melhoria correspondente na qualidade das restaurações fundidas. Não obstante estas observações, quando analisou o comportamento inerente dos materiais de moldagem pesquisados, concluiu que a silicona de adição mostrou-se mais fiel que a mercaptana nas diferentes condições analisadas.

Desta forma, as siliconas de reação por adição vêm gradativamente conquistando a preferência dos profissionais, principalmente pela estabilidade dimensional e por não produzir subprodutos voláteis durante a polimerização, sendo, segundo dados publicados ${ }^{100}$, o material mais utilizado nos Estados Unidos, compreendendo $51 \%$ de preferência pelos americanos, ao lado de $32 \%$ para os poliéteres, $9 \%$ para os polissulfetos, $6 \%$ para os hidrocolóides e $2 \%$ para as siliconas de condensação. No Brasil, de acordo com EDUARDO; MATSON ${ }^{61}$, a silicona de adição ainda apresenta pequena preferência, 7,4\%, sendo a silicona de condensação o material mais utilizado, $63 \%$, e o polissulfeto, intermediário, com $16 \%$ de preferência entre os profissionais.

ARAUJO; JORGENSEN; ARAUJO ${ }^{8}$, salientam igualmente que a silicona de adição não é extensivamente utilizada na América do Sul e que, por outro lado, materiais à base de polissulfeto são comumente empregados. Face a observação feita por ARAUJO; JORGENSEN ${ }^{7}$, de que ocorre uma melhoria na precisão de moldagens obtidas com siliconas de adição pelo reaquecimento dos moldes à $37^{\circ} \mathrm{C}$ por 30 minutos e vazamento subseqüente com gesso, realizaram ${ }^{6}$ uma pesquisa semelhante utilizando um polissulfeto (Permlastic Regular), reaquecendo igualmente os moldes e material para obtenção dos troquéis. Concluíram que o reaquecimento propicia melhor precisão dos troquéis de gesso, provavelmente pela expansão térmica do material de moldagem, ou seja, de $22^{\circ} \mathrm{C}$ para $37^{\circ} \mathrm{C}$, alterando a dimensão interna do molde.

Portanto, a variabilidade de resultados com materiais elásticos mostra, de forma geral, a tendência das técnicas de moldagem e dos diferentes tipos de 
elastômeros, influenciarem, diretamente estes resultados e que há um relacionamento direto, envolvendo a composição, propriedades químicas e físicas, bem como a técnica empregada, que podem induzir a esforços que levam à deformação adicional no molde e, consequentemente, ao troquel e a peça fundida. 


\section{6 - Conclusões}




\section{6 - Conclusões}

Do ponto de vista estatístico, existiram diferenças significantes entre as condições estudadas.

O melhor desempenho (troquéis de gesso morfo-dimensionalmente com valores mais próximos daqueles do troquel-padrão) ocorreram com as condições Impregum F $(7,03)$ e Imprint $(25,71)$, ambos com a técnica do casquete, de forma semelhante. Em seguida, também com desempenho praticamente igual, apresentaram-se as condições Express $(-30,61)$, President $(-42,45)$, ambos com a técnica da dupla moldagem e alívio de $2 \mathrm{~mm}$, e o Express $(-50,74)$, com a mesma técnica, só que com alívio de $1 \mathrm{~mm}$. Em um terceiro bloco, o Permlastic $(59,73)$ mostrou-se semelhante ao Express $(80,82)$, ambos na técnica do casquete; entretanto este também foi semelhante ao President $(102,69)$, na mesma técnica; o pior desempenho foi observado para a condição President $(-107,68)$, na técnica da dupla moldagem e alívio de $1 \mathrm{~mm}$. 
7 - Referências bibliográficas 


\section{7 - Referências bibliográficas}

1. ABBADE, D. O. et al. Estudo Comparativo de duas técnicas de moldagem com material a base de silicona, na verificação das alterações dimensionais das áreas oclusais do dentes preparados. Rev. Gaúcha de Odonto., v.31, n.1, p.11-4, jan./mar. 1983.

2. ABRÃO, W. et al. Influência da condição de armazenamento de moldes de mercaptana nas alterações dimensionais lineares ocorridas nos modelos de gesso-pedra melhorado. Rev. odont. Univ. São Paulo, v.3, n.4, p.448-53, otu./dez. 1989.

3. AMERICAN DENTAL ASSOCIATION. Specification n.19 for non-aqueous, elastometric dental impression materials. J. Amer. dent. Ass., v.94, n.4, p.733-41, Apr. 1977.

4. ANUSAVICE, K. J. Dental impression materials: Reactor Response. Adv. dent. Res., v.2, n.1, p.65-70, Aug. 1988.

5. ARAÚJO, C. R. P. Análise da influência do reaquecimento das moldagens de siliconas de adição e mercaptanas sobre a adaptação de fundição em ligas para metalo-cerâmicas. Bauru, 1989. 89p. tese (Doutorado) Faculdade de Odontologia de Bauru, Universidade de São Paulo.

6. ARAÚJO, P. A.; JÖRGENSEN, K. D. Effect of material bulk and undercuts on the accuracy of impression materials. J. prosth. Dent., v.54, n.6, p.791-4, Dec. 1985.

7. ARAÚJO, P. A.; JÖRGENSEN, K.D. Improved accuracy by reheating additionreaction silicone impressions. J. prosth. Dent., v.55, n.1, p.11-2, Jan. 1986.

8. ARAÚJO, P. A.; JÖRGENSEN, K. D; ARAÚJO, C. R. P. Effect of reheating on the accuracy of polysulfide impression. Rev. Odont. USP., v.4, n.2, p.150-2, Abr./Jun. 1990.

9. ARAÚJO, P. A.; et al. Effect of undercuts on the accuracy of reheated addition reaction silicone impressions. Rev. Odont. USP., v.4, n.3, p.212-5, 1990. 
10. ARAÚJO, P. A. et al. Viscoelastic properties of setting elastomeric impression materials. J. prosth. Dent., v.54, n.5, p.633-6, Nov. 1985.

11. ARAÚJO, M. R. P. et al. Influência do reaquecimento de molde na precisão de modelos em gesso para prótese fixa. Rev. FOB. v.3, n.1/4, p.103-7, jan./dez. 1995.

12. ARIKAWA, H. et al. A method for determination of setting characteristics of elastomeric impression materials. Dent. Mater. J., v.51, n.1, p.67-72, Dec. 1982.

13. ASGAR, K. Elastic impression materials. Dent. Clin. N. Amer., v.15, n.1, p.8198, jan. 1971.

14. ASGHARNIA, M. et al. Surface porosity in stone casts made from polysiloxane impression materials. J. dent. Res., v.62, n.3, p.267, Mar. 1983. Abstract n. $885 /$

15. ASTIZ, P. H.; LORENCKI, S. F. Comparative accuracy of commonly used dental die materials. J. Canad. dent. Ass., v.35, n.6, p.320-3, June 1969.

16. AUGSBURGER, R. H. et al. Accuracy of casts from three impression materials and effect of a gypsum hardener. Oper. Dent., v.6, n.2, p.70-4, 1981.

17. AYERS, H. D. et al. Detail duplication test used to evaluate elastic impression materials. J. prosth. Dent., v.10, n.2, p.374-80, Apr. 1960.

18. BAILEY, L. R. Acrylic resin tray rubber base impression materials. J. prosth. Dent., v.5, n.5, p.658-62, Sept. 1955.

19. BAILEY, J. H.; et al. The dimensional accuracy of improved dental stone, silver plated, and epoxy resin die materials. J. prosth. Dent., v.59, n.3, p.307-10, Mar. 1988.

20. BAROLET, R. Y.; DESAUTELS, P. C. New elastomeric impression materials. J Canad. dent. Ass., v.40, n.7, p.488-9, July 1974.

21. BASSET, R. W.; et al. Clinically oriented tests comparing accuracy of elastic impression materials. J. South Calif. dent. Ass., v.37, p.47-57, Feb. 1969. 
22. BELL, J. W.; FRAUNHOFER, J. A. The handling of elastomeric impression materials: a review. J. Dent., v.3, n.5, p.229-37, Sept. 1975.

23. BELL, J. W. et al. The dimensional changes of elastomeric impression materials under various conditions of humidity. J. Dent., v.4, n.3, p.73-82, Mar. 1976.

24. BLOMBERG, P. A. H. et al. Some parameters for testing deformation of elastomeric impression materials. Aut. dent. J., v.37, n.4, p.271-6, Aug. 1992.

25. BOMBERG, T. J.; HATCH, R. A. Correction of defective impressions by the selective addition of impression materials. J. prosth. Dent., v.52, n.1, p.3840, July 1984

26. BOMBERG, T. J. et al. Consideration for adhesion of impression materials to impression trays. J. prosth. Dent.; v.60, n.6, p.681-4, Dec. 1988.

27. BONACHELA, W. C. Avaliação do desajuste cervical de coroas totais fundidas a partir de moldagens com elastômeros e sistema combinado hidrocolóide reversível/irreversível, vazados em diferentes tempos. Bauru, 1989, 105 p. Dissertação (Mestrado) - Faculdade de Odontologia de Bauru. Universidade de São Paulo

28. BONACHELA, W. C. Avaliação das alterações dimensionais de troquéis de sete marcas comerciais de gessos ( seis tipo IV e um tipo III ), obtidos de moldes de silicona de adição. Bauru, 1991, 160 p. Tese (Doutorado) Faculdade de Odontologia de Bauru. Universidade de São Paulo.

29. BORGES FILHO, P. Avaliação de algumas propriedades de elastômeros através de coroas totais fundidas, moldes e modelos de gesso tipo IV. Bauru, 1981. 83 p. Dissertação (Mestrado) - Faculdade de Odontologia de Bauru, Universidade de São Paulo.

30. BOULTON, J. L. et al. A laboratory study of dimensional changes for three elastomeric impression materials using custom and stock trays. Aust. dent. J., v.41, n.6, p.398-404, Dec. 1996. 
31. BRADEN, M. Dimensional stability of condensation silicone rubber. Biomaterials., v.13, n.5, p.333-6, 1992.

32. BRASS, G. A. Thiokol: A base impression material for restorative techniques. J. Canad. dent. Ass., v.25, n.11, p.745-51, Nov. 1959.

33. BROWN, D. Factors affecting the dimensional stability of elastic impression materials. J. Dent., v.1, n.1, p.265-74, 1973.

34. BROWN, D. An update on elastomeric impression materials. Brit. dent. J., v.150, n.20, p.53-40, Jan. 1981.

35. CALOMENI; A. A. Awash technique using rubber base impression materials. J. prosth. Dent., v.25, n.5, p.520-4, May 1971.

36. CAREY, D. O. Rubber base impression technique. Dent. Dig., v.72, n.12,p. 5467, Dec. 1966.

37. CHAI, J. Y.; YEUNG, T. C.. Wettability of nonaqueous elastomeric impression materials. Int. J. Prosthodont., v.4, n.6, p.555-60, Nov./Dec. 1991.

38. CHAI, J. Y. et al. Adhesive properties of several impression materials systems: Part I. J. prosth. Dent., v.66, n.2, p.201-9, Aug. 1991.

39. CHEE, W. W. L; DONOVAN, T. E. Polyvinyl siloxane impression materials: A review of properties and techiniques. J. prosth. Dent., v.68, n.5, p.728-32, Nov. 1992.

40. CHEVITARESE, O.; SCELZA, P.; AMARANTE, R. Moldagem complementar: adaptação de moldeira de estoque à condição de moldeira individual. Rev. bras. Odont., v. 40, n.5, p. 29-37, set/out. 1983.

41. CHONG, M. P.; DOCKING, A. R. Some characteristics of elastomeric impression materials. Aust. dent. J., v.14, n.5, p.295-301, Oct. 1969.

42. CHONG, Y. H. et al. The relationship between contact angles of die stone on elastomeric impression materials and voids in stone casts. Dent. Mat., v.6, n.3, p.162-6, July 1990.

43. CHONG, Y. H. et al. Porosities in five automixed addition silicone elastomers. Oper. Dent., v.16, n.3, p.96-100, May/June 1991. 
44. CIESCO, N. J. et al. Comparasion of elastomeric impression materials used in fixed prosthodontics. J. prosth. Dent., v.45, n.1, p.89-94, Jan. 1981.

45. CLANCY, J. M. S. et al. Long-term dimensional stability of three current elastomers. J. oral Rehab., v.10, n.4, p.325-33, July 1983.

46. COLLARD, E. W. et al. An acceptable photoelastic simulation of mercaptan rubber impression materials. J. South. Calif. dent. Ass., v.38, p.506-11, 1973.

47. COMBE, E. C.; GRANT, A. A. The selection and properties of materials for dental practice: 5-impressions materials. Brit. dent. J., v.134, p.197-200, 1973.

48. COMBE, E. C. MOSER, J. B. The rheological characteristics of elastomeric impression materials. J. dent. Res., v.57, n.2, p.221-6, Feb. 1978.

49. CONTIN, I; UETI, M. Alteração dimensional de troquel em função das técnicas de moldagem e de tempos de preenchimento do molde. Rev. Fac. Odont. S. Paulo, v.23, n.2, p.115-20, jul./dec. 1985.

50. CRAIG, R. G. A review of properties of rubber impression materials. J. Mich. dent., v.59, p.254-61, 1977.

51. CRAIG, R. G. Evaluation of an automatic mixing system for an addition silicone impression material. J. Amer. dent. Ass., v.110, n.2, p.213-5, Feb. 1985.

52. CRAIG, R. G. Review of dental impression materials. Adv. dent. Res., v.2, n.1, p.51-64, Aug. 1988.

53. CRAIG, R. G. et al. Comparasion of commercial elastomeric impression materials. Oper. Dent., v.15, n.3, p.94-104, May/June 1990.

54. CULLEN, D. R.; et al. Wettability of elastomeric impression materials and voids in gypsum casts. J. prosth. Dent., v.66, n.2, p.261-5, Aug. 1991

55. CUSTER, F. et al. Accuracy and dimensional stability of a silicone rubber base impression material. J. prosth. Dent., v.14, n.6, p.1115-21, NovlDec. 1964.

56. DARVELL, B.W. Aspects of the chemistry of polysulfide impression material. Aust. dent. J., v.32, n.5,p. 357-67, Oct. 1987. 
57. DAVIS, G. B., et al. The bonding properties of elastomer tray adhesives. J. prosth. Dent., v.36, n.3, p.278-85, Sep. 1976.

58. DHURU, V. B., et al. Surface porosity of stone cast made from vinyl polysiloxane impression materials. Oper. Dent., v.11, n.3-7, 1986.

59. DRUMMOND, J. L.; RANDOLPH, R. G. Comparasion study of elastic impression material. J. prosth. Dent., v.56, n.2, p.188-92, Aug 1986.

60. EAMES, W. B. et al. Accuracy and dimensional stability of elastomeric impression materials. J. prosth. Dent., v.42, n.2, p.159-62, Aug. 1979.

61. EDUARDO, C. P; MATSON, E. Moldagem em prótese unitária. São Paulo, Ed. Santos, 1996. p. 39-78.

62. EDUARDO, C. P.; MATSON, E.; FICHMAN, D. M. Contribuição para o estudo da alteração dimensional de moldagens com alívio e sem alívio, com materiais à base de silicona. Rev. paul. Odont., v. 10, n. 3, p. 13-33, 1988.

63. FAIRHURST, C. W. et al. Elastic properties of rubber-base impression materials. J. prosth. Dent., v.6, n.4, p.534-42, 1956.

64. FARAH, J. W. et al. Elastomeric impression materials. Oper. Dent., v.6, n.1, p.15-9, 1981.

65. FEDERICK, D. R; CAPUTO, A. Comparing the accuracy of reversible hydrocolloid and elastomeric impressiosn materials. J. Amer. dent. Ass., v 128, n.2, p.183-8, Feb. 1997.

66. FINGER, W., OHSAWA, M. Accuracy of stone-casts produced from selected addition-type silicone impressions. Scand. J. dent. Res., v.91, n.1, p.61-5, Feb. 1983.

67. FUSAYAMA, T. et al. Accuracy of the laminated single impression technique with silicone materials. J. prosth. Dent., v.32, p.270-6, Sep. 1974.

68. GRANT, B. E.; TJAN, A. H. L. Tensile and peel bond strengths of tray adhesives. J. prosth. Dent., v.59, n.2, p. 165-8, Feb 1998.

69. GOLDBERG, A. J. Viscoelastic properties of silicone, polysulfide and polyether impression materials. J. dent. Res., v.53, n5, p.1033-9, Sept./Oct. 1974. 
70. GORDON, G. E. et al. The effect of tray selection on the accuracy of elastomeric impression materials. J. prosth. Dent., v.63, n.1, p.12-5, Jan. 1990.

71. GUIDI, D. et al. Estudo de fidelidade de moldes unitários de silicone ou polissulfeto em função da espessura do material e da técnica de moldagem. Rev. Fac. Odont. S. Paulo, v.14, n.1, p. 23-8, 1976.

72. GULKER, I. An evaluation of impression materials. N. Y. St. dent. J., v.49, n.8, p.555-7, Oct. 1983.

73. GULlETT, C. E.; PODSHADLEY, A. G. Cost analysis of relined mercaptan rubber impressions. J. prosth. Dent., v.42, n.2, p. 180-2, Aug. 1979

74. HABU, H.; KOBAYASHI, K. Three-dimensional measurement of stone cast deformation. Nihon Univ. dent. J., v.28, n.6, p.51-60, 1986.

75. HARCOURT, J. K. A review of modern impression materials. Aust. dent. J., v.23, n.2, p.178-86, Apr. 1978.

76. HENRY, P. J.; HARNIST, D. J. R. Dimensional stability and accuracy of rubber impression materials. Aust. dent. J., v.19, n.3, p.162-6, June 1974.

77. HONDRUM, S. O. - Tear and energy properties of three impression materials. Int. J. Prosthodont., v. 7, n. 6, p. 517-21, Nov./Dec. 1994.

78. HOUGANS, W. R.; AGAR, J. R. The bond strength of elastomer tray adhesives to thermoplastic and acrylic resin tray materials. J. prosth. Dent., v.67, n.4, p.541-3, Apr. 1992.

79. INOUE, K.; WILSON, H. J. Viscoelastic properties of elastomeric impression materials. I. a method of measuring shear modulus and rigidity during setting. J. oral Rehab., v.5, n.1, p.89-94, Jan. 1978.

80. INOUE, K.; WILSON, H. J. Viscoelastic properties of elastomeric impression materials II: variation of rheological properties with time, temperature and mixing proportion. J. oral. Rehab., v.5, p. 261-7, July 1978.

81. INOUE, K. WILSON, H. J. Viscoelastic properties of elastomeric impression materials. III. The elastic recovery after removal of strains applied at the setting time. J. oral Rehab., v.5, n.4, p.322-7, Oct. 1978. 
82. JOHNSON, G. H.; CRAIG, R. G. Accuracy of addition silicones as a function of technique. J. prosth. Dent., v.55, n.22, p.197-203, Feb. 1986

83. JÖRGENSEN, K. D. Thermal expansion of addition polimerization (tipy II) silicone impression materials. Aust. dent. J., v.6, p.377-81, Dez. 1982.

84. KALOYANNIDES, T. M. Elasticity of elastomer impression materials: II Permanent deformation. J. dent. Res., v. 52, n.4, p.719-24, July/Aug. 1973.

85. KEMPLER, D. et al. Clinical manipulative properties of silicone impression materials. Quintessence Int., v.14, n.9, p.893-7, Sep. 1983.

86. KOBAYASHI, K. Three-dimensional study related to the dimensional accuracy and deformation of stone casts. A collection of doctoral dissertation at Nihon University Graduate School of Dentistry. s. 1., 1986. p. 203-4.

87. LACY, A. M. et al. Time-dependent accuracy of elastomer impression materials. Part I: Consensation silicones. J. prosth. Dent., v.45, n.2, p.209-15, Feb. 1981.

88. LACY, A. M. et al. Time-dependent accuracy of elastomer impression materials. Part II: Polyether, polysulfides and polyvinylsiloxane. J. prosth. Dent., v.45, n.3, p.329-33, Mar. 1981.

89. LAUFER, B, et al. The linear accuracy of impressinos and stone dies as affected by the thickness of the impression margin. Int. J. prosthodont., v.7, ..3, p.247-52, May/June 1994.

90. LEPE, X. et al. Effect of mixing technique on surface characteristics of impression materials. J. prosth. Dent., v79, n.5, p.495-502, May 1998.

91. LEWINSTEIN, I.; CRAIG, R. G. Accuracy of impression materials measured with a vertical height gauge. J. oral Rehab., v.17, p. 303-10, July 1990

92. LIBANORI, C. M. B.; EDUARDO, C. P. Silicona de adição. Moldagem em prótese unitária. Rev. paul. Odont., v.12, n.5, p.26-37, Set/Out. 1990. 
93. LIM, K. C.; et al. Effect of operator variability on void formation in impression made with an antomixed addition silicone. Aust. Dent. J., v.37, n.1, p. 35-8, Feb. 1992.

94. LINKE, B. A. et al. Distorcion analysis of stone casts made from impression materials. J. prosth. Dent., v.54, n.6, p.794-802, Dec. 1985.

95. LORREN, R. A. et al. The contact angles of die stones on impression materials. J. prosth. Dent., v.36, n.2, p.176-80, Aug. 1976.

96. MANSFIELD, M. A.; WILSON, H. J. Elastomeric impression materials. A method of measuring dimensional stability. Brit. dent. J., v.139, n.7, p.26772, Oct. 1975.

97. MARCHESE, M. P. Dois métodos de avaliação da fidelidade morfodimensional de troquéis de gesso, obtidos a partir de moldes de elastômeros, com ou sem reaquecimento. Bauru, 1994, 129 p. Dissertação (Mestrado) - Faculdade de Odontologia de Bauru. Universidade de São Paulo.

98. MARCINACK, C. F. et al. Linear dimensional changes in elastic impression materials. J. dent. Res., v.59, n.7, p.1152-5, July 1980.

99. MARCINACK, C. F.; DRAUGHN, R. A. Linear dimensional changes in addition curing silicone impression materials. J. prosth. Dent., v.47, n.4, p.441-3, Apr. 1982

100. MATERIAIS de moldagem para prótese fixa. Dent. Adv..(ed. port.), v.5, n.1, p.5, fev. 1998.

101. MAZZETTO, M. O. et al. Estudo comparativo da capacidade dos elastômeros na reprodução e transferência de detalhes para os modelos de gesso. Rev. Odont. USP., v.4, n.2, p.144-9, abr/jun. 1990.

102. McCABE, J. F.; WILSON. H. J. Addition curing silicone rubber impression materials. An appraisal of their physical properties. Brit. dent. J., v.145, n.4, p.17-20, July 1978. 
103. McCABE, J. F.; STORER, R. Elastomeric impression materials: The measurement of some properties relevant to clinical pratice. Brit. dent. J., v.149, n.5, p.73-9, Aug. 1980.

104. McCROSSON, J. et al. Quantification of hidrogen gas released from polyvinylsiloxane impression materials in contact with die stone materials. J. Dent., v.15, n.3, p.129-32, June 1987.

105. McLEAN, J. W. Silicone impression material. Brit. dent. J., v.104, n.12, p. 44151, June 1958.

106. McLEAN, J. W. Physical properties influencing the accuracy of silicone and thiokol impression materiasl. Brit. dent. J., v.110, n.3, p.85-91, Feb. 1961.

107. MENEZES, M. A. Estudo comparativo de alguns materiais de moldagem elastoméricos submetidos a técnica de reaquecimento. Bauru, 1988, 73p. Dissertação ( Mestrado ) - Faculdade de Odontologia de Bauru, Universidade de São Paulo.

108. MILLAR, B. J. et al. In vitro study of the number of surface defects in monophase and two-phase addition silicone impressions. J. prosth. Dent. V.80, n.1, p. 32-5, July 1998.

109. MILLER, W. A.; et al. Physical properties of synthetic rubber-base impression material. J. Amer. dent. Ass., v.60, p.211-23, Feb. 1960.

110. MILlER, N.; MYERS, G. E. Silicone impression materials. J. prosth. Dent., v.12, n.5, p. 951-61, Sep/Oct. 1962.

111. MITCHELL, J. V.; DAMELE, J. J. Influence of tray desing upon elastic impression materials. J. prosth. Dent., v.23, n.1, p.51-7, Jan. 1970.

112. NORLING, B. K.; REISBICK, M. H. The effect of nonionic surfactants on bubble entratment in elastomeric impression materials. J. prosth. Dent., v.42, n.3, p. 342-7, Sep. 1979.

113. OHSAWA, M.; JÖRGENSEN, K. D. Curing contraction of addition-type silicone impression materials. Scand. J. dent. Res., v.91, n.1, p.51-4, Feb. 1983. 
114. OMANA, H. M. et al. Compatibility of impression and die stone material. Oper. Dent., v.15, n.3., p.82-5, May/June 1990.

115. PAMENIUS, M.; OHLSON, N. G. The clinical relevance of mechanical properties of elastomers. Dent. Mat., v. 3, n. 5, p. 270-4, Oct.1987.

116. PANICHUTTRA, R. et al. Hydrophilic poly (vinyl siloxane) impression materials: Dimensional accuracy, wettability, and effect on gypsum hardness. Int. J. Prosthodont., v.4, n.3, p. 240-8, 1991.

117. PAYNE, J. A.; PEREIRA, B. P. Bond strengh of two nonaqueous elastomeric impression materials bonded to two thermoplastic resin tray materials. J. prosth. Dent., v.74, n.6, p.563-8, Dec. 1995.

118. PETERSEN, G. A.; ASMUSSEN, E. Distortion of impression materials used in the duble-mix technique. Scand. J. dent. Res., v.99, p. 343-8, Aug. 1991.

119. PEUTZFELDT, A.; ASMUSSEN, E. Accuracy of alginate and elastomeric impression materials. Scand. J. dent. Res., v.97, n.4, p. 375-9, Aug. 1989.

120. PHILLIPS, R. W. Physical properties and manipulation of rubber impression materials. J. Amer. dent. Ass., v.59, p.454-8, Sep. 1959.

121. PHILlIPS, R.W. SKINNER materiais dentários. $9^{\text {a }}$ ed. Rio de Janeiro, Guanabara Koogan, 1993. p. 77-90.

122. PINTO, J. H. N.; et al. Influência do alívio em moldagens com silicona de adição no desajuste cervical das infra-estruturas metálicas. Rev. Odont. USP., v.7, n.4, p.269-72, out./dez. 1993.

123. PODSHADLEY, A. G.; et al. Accuracy of relived mercaptan-rubber impressions. J. prosth. Dent., v.24, n.5, p. 503-11, Nov. 1970.

124. PODSHADLEY, A. G. et al. Accuracy of a mercaptan rubber impression technique using a stock tray. J. Amer. dent. Ass., v. 83, n.6, p. 1303-8, Dec. 1971.

125. PRATTEN, A. G.; CRAIG, R. G. Wettability of a hidrophilic addition silicone impression material. J. prosth. Dent., v.61, n.2, p.197-202, Feb. 1989. 
126. PRICE, B. R. et al. The dimensional accuracy of 12 impression material and die stone combination. Int. J. Prosthodont., v.4, n.2, p. 169-74, Mar./Apr.1991.

127. REISBICK, M. H. Effect of viscosity on the accuracy and stability of elastic impression materials. J. dent. Res., v.52, n.3, p.407-17, May/June 1973.

128. REISBCK, M. H.; MATYAS, J. The accuracy of highly filled elastomeric impression materials. J. prosth. Dent., v.33, n.1, p.67-72, Jan. 1975.

129. ROBINSON, P. B. et al. An in vitro study of a surface wetting agent for addition reaction silicone impressions. J. prosth. Dent., v.71, n.4, p. 390-3, Apr. 1994.

130. SANSIVIERO, A. et al. Estudo da precisão dimensional de modelos de trabalho construídos a partir da moldagem múltipla de preparos cavitários. I Siliconas. Rev. Fac. odont. São José dos Campos, v.3, n.2. p.85-9, Jul/Dez. 1974.

131. SAWYER, H. F. et al. Accuracy of casts from the three classes of elastomeric impression materials. J. Amer. dent. Ass., v.89, n.3, p.644-9, Sep. 1974.

132. SCHELB, E. et al. Compatibility of type IV dental stones with polyvinyl siloxane impression materials. J. prosth. Dent., v.58, n.1, p.19-22, July 1987.

133. SCHELB, E. Using a syringe to make void-free casts from elastomeric impressions. J. prosth. Dent., v.60, n.1, p. 121-2, July 1988.

134. SCHELB, E. et al. Surface detail reproduction of type IV dental stones with selected polyvinyl siloxane impression materials. Quintessence Int., v.22, n.,1, p. 51-5, Jan. 1991.

135. SCHNELL, R. J.; PHILLIPS, R. W. Dies for measuring accuracy of impressions. Dent. Progr., v.2, n.4, 249-55, July 1962.

136. SKINNER, C. W.; COOPER, E. N. Desirable properties and use of rubber impression materials. J. Amer. dent. Ass., v.51, n.5, p.523-37, Nov. 1955.

137. SKINNER, C. W. Properties and manipulations of mercaptan base and silicone base impression material. Dent. Clin. N. Amer., p.685-97, Nov. 1958. 
138. SNEED, W. D. et al. Tear strenght of ten elastomeric impression materials. J. prosth. Dent., v.49, n.4, p.511-3, Apr. 1983.

139. SOH, G.; CHONG, Y. H. Defect in automixed addition silicone elastomers prepared by putty-wash impressin technique. J. oral Rehab., v.18, n.6, p.547-53, Nov. 1991.

140. SPYRIDES, G. M. et al. Moldagem com casquete de resina/elastômero: método alternativo e simplificado para obtenção do casquete de acrílico. Rev. bras. Odont., v.55, n.3, p. 160-4, 1998.

141. STACKHOUSE JR., J. A. The accuracy of stones die made form rubber impression materials. J. prosth. Dent., v. 24, n.4, p. 377-86, Oct. 1970.

142. STACKHOUSE JR., J. A. A comparison of elastic impression materials. J. prosth. Dent., v.34, n.3, p. 305- 13, Sept.1975.

143. STURDEVAnt, C. M. Impressions for indirect inlays. J. Amer. dent. Ass., v.54, p.357-66, Mar. 1957.

144. TJAN, A. H. L. et al. Effect of tray space on the accuracy of monophasic polyvinysiloxane impressin. J. prosth. Dent., v.68, n.1, p.19-28, July 1992.

145. TAM, L. E.; BROWN, J. W. The tear resistance of various impression materials with and without modifiers. J. prosth. Dent., v.63, n.3, p. 282-5, Mar. 1990.

146. TEIXEIRA, M. Análise da influência do reaquecimento dos moldes de alguns materiais elastoméricos, através dos troquéis de gesso obtidos. Bauru, 1993, 256 p. Dissertação (Doutorado) - Faculdade de Odontologia de Bauru, Universidade de São Paulo.

147. TOLLEY, L. G.; CRAIG, R.G. Viscoelastic properties of elastomeric impression materials: polysulphide, silicone and polyether rubbers. J. oral Rehab., v.5, n.2, p.121-8, Apr. 1978.

148. VAllE, A. L. Avaliação do desajuste cervical de coroas totais fundidas a partir de moldagens obtidas com moldeira e casquete individual, utilizando três tipos de materiais à base de borracha. Bauru, 1978. $91 \mathrm{p}$. 
Tese (Doutorado) - Faculdade de Odontologia de Bauru, Universidade de São Paulo.

149. VALDERHAUG, J.; FLÖYSTRAND, F. Dimensional stability of elastomeric impression materials in custom-made and stock trays. J. prosth. Dent., v.52, n.4, p.514-7, Oct. 1984.

150. WALTERS, R. A.; SPURRIER, S. An effect of tray desing and material retention on the linear dimensional changes in polysulfide impressions. J. prosth. Dent., v.63, n.3, p.277-81, Mar. 1990.

151. WASSEL, R. W.; IBBETSON, R. J. The accuracy of polyvinyl siloxane impressions made with standard and reinforced stock trays. J. prosth. Dent., v.65, n.6, p.748-57, Jun. 1991.

152. WILLIAMS, P. T. et al. An evaluation of time-dependent stability of eleven elastomeric impression materials. J. prosth. Dent., v.52, n.1, p.120-5, July 1984.

153. WILSON, H.J. Impression materials. Brit. dent. J., v. 164, n. 7, p. 221-5, Apr. 1988. 
8 - Abstract 


\section{8 - Abstract}

Fixed restorations are usually produced on gypsum dies obtained from a prepared tooth mold and its precise adaptation is directly influenced by the properties of the impression materials. The objective of this study was to compare the performance of five impression materials and different methods of impression. Materials were tested using the putty-wash method being the first impression realeased in 1 or $2 \mathrm{~mm}$ (for Express and President) and the individual resin tray shell (Express, Impregum F, Imprint, Permlastic e Predident). The deviced used by ARAÚJO; JÖRGENSEN ${ }^{6}$ and the VelMix (type IV) gypsum were used. The adaptation of one standard-crown to the dies was analysed with a depth measuring microscope. The results showed that Impregum F and Imprint (with a shell) gave the best results, followed by Express and President (putty/wash $-2 \mathrm{~mm}$ ) and Express (putty/wash $-1 \mathrm{~mm}$ ). The results with Permlastic and Express (shell) were less satisfactory and the difference between them wasn't statistically significant. Express (shell) was not statistically different from the President (shell), and the worse result was given by the President (putty/wash - $1 \mathrm{~mm}$ ) when compared to all the others. 
9 - Apêndice 


\section{9 - Apêndice}

Tabela 9.1 - Medidas médias originais da adaptação da coroa-padrão nos troquéis de gesso, nos quatro locais escolhidos.

\begin{tabular}{|c|c|c|c|c|c|c|c|c|c|}
\hline \multicolumn{5}{|c|}{ EXPRESS - dupla $1 \mathrm{~mm}$} & \multicolumn{5}{|c|}{ PRESIDENT - dupla $1 \mathrm{~mm}$} \\
\hline $\mathrm{N}$ & M3h & M6h & M9h & M12h & $\mathrm{N}$ & M3h & M6h & M9h & M12h \\
\hline 1 & $-80,0$ & $-93,0$ & $-97,33$ & $-85,7$ & 1 & $-83,3$ & $-86,7$ & -99 & $-71,7$ \\
\hline 2 & $-50,0$ & $-47,7$ & $-45,7$ & $-72,3$ & 2 & $-185,7$ & $-143,7$ & $-90,3$ & $-122,7$ \\
\hline 3 & $-17,3$ & $-5,0$ & $-0,3$ & $-12,7$ & 3 & $-147,3$ & $-144,7$ & $-176,3$ & $-116,3$ \\
\hline 4 & $-57,7$ & $-40,7$ & $-56,0$ & $-57,0$ & 4 & $-127,7$ & $-121,3$ & $-110,7$ & $-133,3$ \\
\hline 5 & $-100,0$ & $-89,7$ & $-78,3$ & $-90,7$ & 5 & $-65,3$ & $-72,0$ & $-73,3$ & $-73,3$ \\
\hline 6 & $-50,0$ & $-34,0$ & $-59,0$ & $-57,3$ & 6 & $-100,7$ & $-84,0$ & $-97,7$ & $-103,3$ \\
\hline 7 & $-44,7$ & $-23,7$ & $-34,0$ & $-39,3$ & 7 & $-101,7$ & $-88,7$ & $-78,3$ & $-112,3$ \\
\hline 8 & $-52,7$ & $-62,3$ & $-48,7$ & $-39,7$ & 8 & $-148,0$ & $-143,7$ & $-115,3$ & $-115,3$ \\
\hline 9 & $-16,3$ & $-9,7$ & $-1,3$ & $-7,3$ & 9 & $-77,3$ & $-74,0$ & $-77,3$ & $-71,7$ \\
\hline 10 & $-74,3$ & $-67,0$ & $-63,7$ & $-67,7$ & 10 & $-123,0$ & $-109,3$ & $-107,7$ & $-132,3$ \\
\hline
\end{tabular}

\begin{tabular}{|c|c|c|c|c|c|c|c|c|c|}
\hline \multicolumn{5}{|c|}{ EXPRESS - dupla $2 \mathrm{~mm}$} & \multicolumn{5}{|c|}{ PRESIDENT - dupla $2 \mathrm{~mm}$} \\
\hline $\mathrm{N}$ & M3h & M6h & M9h & M12h & $\mathrm{N}$ & M3h & M6h & M9h & M12h \\
\hline 1 & $-14,7$ & $-22,3$ & -12 & $-17,7$ & 1 & $-65,0$ & $-36,7$ & $-6,7$ & $-6,7$ \\
\hline 2 & $-12,0$ & $-24,7$ & $-20,7$ & $-25,7$ & 2 & $-20,0$ & 0,0 & $-20,0$ & $-10,3$ \\
\hline 3 & $-40,0$ & $-25,3$ & $-39,7$ & $-55,3$ & 3 & $-26,7$ & $-9,0$ & $-19,0$ & $-17,3$ \\
\hline 4 & $-77,0$ & $-80,0$ & $-73,3$ & $-25,7$ & 4 & $-10,0$ & $-46,0$ & $-169,7$ & $-1,7$ \\
\hline 5 & $-22,7$ & $-20,0$ & $-15,7$ & $-23,0$ & 5 & $-62,3$ & $-46,7$ & $-36,0$ & $-55,7$ \\
\hline 6 & $-11,3$ & $-20,3$ & $-20,7$ & $-31,7$ & 6 & $-58,3$ & $-60,7$ & $-65,0$ & $-51,7$ \\
\hline 7 & $-57,7$ & $-66,0$ & $-44,3$ & $-44,7$ & 7 & $-17,7$ & $-159,0$ & $-75,0$ & $-44,7$ \\
\hline 8 & $-14,3$ & $-16,7$ & $-20,3$ & $-23,3$ & 8 & $-10,0$ & $-7,3$ & $-19,3$ & $-9,0$ \\
\hline 9 & $-16,0$ & $-20,0$ & $-12,3$ & $-14,3$ & 9 & $-49,3$ & $-23,3$ & $-50,7$ & $-20,3$ \\
\hline 10 & $-31,7$ & $-32,0$ & $-39,7$ & $-39,0$ & 10 & $-17,3$ & $-128,3$ & $-162,0$ & $-3,3$ \\
\hline
\end{tabular}

\begin{tabular}{|c|c|c|c|c|c|c|c|c|c|}
\hline \multicolumn{5}{|c|}{ EXPRESS - casquete } & \multicolumn{5}{|c|}{ IMPREGUM F- casquete } \\
\hline $\mathrm{N}$ & M3h & M6h & M9h & M12h & $\mathrm{N}$ & M3h & M6h & M9h & M12h \\
\hline 1 & 122,0 & 122,3 & 124,33 & 119,0 & 1 & 10,7 & 11,0 & 4 & 2,0 \\
\hline 2 & 81,3 & 65,0 & 57,0 & 73,0 & 2 & 13,7 & 0,0 & 4,7 & 12,7 \\
\hline 3 & 76,0 & 73,7 & 62,0 & 51,0 & 3 & 3,3 & 10,7 & 1,3 & 1,0 \\
\hline 4 & 59,3 & 63,0 & 67,3 & 63,7 & 4 & 8,3 & 0,3 & 11,7 & 16,3 \\
\hline 5 & 99,7 & 98,7 & 102,3 & 97,3 & 5 & 2,3 & 3,7 & 16,0 & 19,3 \\
\hline 6 & 96,0 & 83,3 & 90,7 & 98,7 & 6 & 1,0 & 2,3 & 4,0 & 1,3 \\
\hline 7 & 78,0 & 67,0 & 72,3 & 68,3 & 7 & 8,0 & 3,7 & 9,7 & 13,7 \\
\hline 8 & 81,3 & 85,0 & 78,3 & 92,3 & 8 & 3,0 & 7,3 & 15,3 & 15,0 \\
\hline 9 & 78,0 & 77,3 & 86,0 & 80,3 & 9 & 4,7 & 7,3 & 0,3 & 1,0 \\
\hline 10 & 67,0 & 56,0 & 55,0 & 63,7 & 10 & 13,3 & 0,7 & 3,7 & 12,3 \\
\hline
\end{tabular}




\begin{tabular}{|c|c|c|c|c|c|c|c|c|c|}
\hline \multicolumn{5}{|c|}{ IMPRINT - casquete } & \multicolumn{5}{|c|}{ PERMLASTIC - casquete } \\
\hline $\mathrm{N}$ & M3h & M6h & M9h & M12h & $\mathrm{N}$ & M3h & M6h & M9h & M12h \\
\hline 1 & 35,3 & 29,3 & 16 & 40,3 & 1 & 38,7 & 52,3 & 63 & 46,0 \\
\hline 2 & 29,7 & 31,0 & 33,0 & 33,7 & 2 & 29,7 & 34,0 & 30,7 & 35,7 \\
\hline 3 & 9,3 & 13,7 & 10,3 & 2,7 & 3 & 50,0 & 53,0 & 63,0 & 58,3 \\
\hline 4 & 16,7 & 12,0 & 13,7 & 21,0 & 4 & 52,7 & 57,0 & 66,0 & 56,7 \\
\hline 5 & 11,7 & 19,3 & 4,3 & 17,7 & 5 & 66,3 & 55,7 & 55,3 & 50,7 \\
\hline 6 & 39,7 & 34,3 & 38,3 & 37,0 & 6 & 72,0 & 74,3 & 63,3 & 60,7 \\
\hline 7 & 52,3 & 50,3 & 47,3 & 49,7 & 7 & 55,3 & 60,3 & 68,0 & 63,3 \\
\hline 8 & 11,0 & 10,7 & 5,7 & 2,3 & 8 & 62,7 & 68,7 & 68,0 & 69,0 \\
\hline 9 & 45,3 & 69,3 & 33,7 & 55,0 & 9 & 73,7 & 71,7 & 68,7 & 77,7 \\
\hline 10 & 11,3 & 3,3 & 13,0 & 18,3 & 10 & 70,0 & 76,7 & 72,3 & 77,7 \\
\hline
\end{tabular}

\begin{tabular}{|c|c|c|c|c|}
\hline \multicolumn{5}{|c|}{ PRESIDENT - casquete } \\
\hline $\mathrm{N}$ & M3h & M6h & M9h & M12h \\
\hline 1 & 143,3 & 138,3 & 134,33 & 136,0 \\
\hline 2 & 123,3 & 138,7 & 122,3 & 121,7 \\
\hline 3 & 73,0 & 103,7 & 83,7 & 77,7 \\
\hline 4 & 134,7 & 121,3 & 86,0 & 125,0 \\
\hline 5 & 126,3 & 131,3 & 120,7 & 127,3 \\
\hline 6 & 34,7 & 47,3 & 40,3 & 45,0 \\
\hline 7 & 145,3 & 143,0 & 141,0 & 148,3 \\
\hline 8 & 71,7 & 76,3 & 75,0 & 74,0 \\
\hline 9 & 40,7 & 49,7 & 32,7 & 44,7 \\
\hline 10 & 148,7 & 131,3 & 124,3 & 125,0 \\
\hline
\end{tabular}

